\title{
CAPACITAÇÃO PARA EDUCAÇÃO \\ NUTRICIONAL DIRIGIDA A PROFESSORES DE UM CURSO DE EDUCAÇÃO INFANTIL
}

\section{IRENE COUTINHO DE MACEDO}

Dissertação de Mestrado apresentada ao Departamento de Nutrição da Faculdade de Saúde Pública da Universidade de São Paulo para obtenção do Grau de Mestre.

Área de concentração: Nutrição 
Autorizo, exclusivamente para fins acadêmicos e cientificos, a reprodução total ou parcial desta dissertação, por processos fotocopiadores.

Assinatura: Gue pauas
Data: 
Tudo o que sou e o que vier a ser eu ofereço a Deus 


\section{AGRADECIMENTOS}

Meus sinceros agradecimentos às seguintes pessoas, que contribuíram de maneira relevante para a concretização deste trabalho:

À Profa. Dra. ANA MARIA CERVATO MANCUSO por sua orientação, amizade e pronta disposição em atender-me a qualquer hora, mostrando que há sempre uma melhor maneira de apresentar as idéias.

À Profa. Dra. ANA MARIA DIANEZI GAMBARDELLA, por seu envolvimento incondicional, pelas preciosas sugestões e encorajamento tão necessários nos momentos mais críticos do desenvolvimento do trabalho e por seu 'divã' sempre à disposição.

À Profa. Dra. AlESSANDRA GOTUZO SEABRA CAPOVILlA por sua doce presença e sugestões relevantes para o aprimoramento deste trabalho.

Ao Prof. Dr. JOSÉ NEMÉSIO MACHADO por ser incentivador ao estudo, criador de condições para o aperfeiçoamento e crescimento profissional de seus funcionários.

Às coordenadoras ELEIR PARRA MORALES EVANGELISTA e ELIENAI MOREIRA COSTA que acreditaram na importância do desenvolvimento deste trabalho e criaram condições para que a idéia se concretizasse.

Às professoras e educadoras do curso de Educação Infantil do Colégio Batista Brasileiro por participarem com boa disposição e colocarem em prática as idéias sugeridas.

À amiga MARIA DE FÁTMA COLLA DOS SANTOS pela cuidadosa revisão ortográfica e pela maravilhosa aula de português. 
Ao cunhado JOSUÉ SAMPAIO SILVA e à amiga CRISTIANE HELGA YAMANE, pelo suporte na informática.

Aos meus irmãos ELISA, ELIZEU e GAMA, e ao meu cunhado JOSHUA, mestres e doutores que me apoiaram e não economizaram esforços para facilitar minha caminhada acadêmica.

Ao MOISÉS, meu amigo, namorado e marido, por ter me suprido de amor, carinho e compreensão em todos os momentos, incentivando e acreditando que sonhos podem se tornar realidade.

Aos meus filhos LARISSA, MATHEUS e ANDRÉ por enriquecerem a minha existência e me fazerem lembrar a cada dia, o quanto essa vida vale à pena.

Aos meus pais ELIAS e IRACEMA, meus maiores professores, que ensinaram com suas próprias vidas os mais ricos princípios de integridade, coragem e persistência, que me permitiram chegar até aqui. 
"Eduque a criança segundo os objetivos que você tem para ela, e mesmo com o passar dos anos não se desviará deles."

Provérbios 22.6 (NVI) 


\section{RESUMO}

\section{Macedo IC. Capacitação para educação nutricional dirigida a professores de um}

curso de educação infantil. São Paulo; 2003. [Dissertação de Mestrado - Faculdade de Saúde Pública da Universidade de São Paulo].

Objetivo: A educação nutricional para crianças tem sido a estratégia sugerida para conter o avanço da prevalência de doenças crônicas não transmissíveis. Nesse sentido, realizou-se estudo com objetivo de avaliar uma estratégia de capacitação em educação nutricional para professores e educadores de um curso de educação infantil de uma escola da rede particular de ensino do município de São Paulo. Metodologia: $O$ estudo foi realizado com 30 professores de crianças com idades entre 1 e 6 anos. $O$ desenvolvimento da pesquisa aconteceu em três etapas: 1) Avaliação diagnóstica aplicação de um questionário para avaliar o grau de conhecimento dos professores sobre alimentação e nutrição; 2) Avaliação do impacto da intervenção educativa nos conhecimentos sobre nutrição - um ano após a intervenção educativa, os professores responderam ao mesmo questionário aplicado na primeira fase; 3) Avaliação das repercussões da intervenção educativa - para a avaliação do impacto das atividades, também se considerou os depoimentos dos professores, das crianças e dos pais. Intervenção Educativa: Foi conduzido encontro com os professores (treinamento), utilizando material didático para servir de apoio às atividades educativas. Resultados: A população estudada foi composta em $100 \%$ por elementos do sexo feminino com média de idade de 35,3 anos (desvio padrão $=11,3$ anos), a maioria (65\%) com curso superior completo e $21 \%$ com curso de pós graduação. A análise revelou efeito estatisticamente significante para aumento de conhecimento antes e após intervenção. $O$ valor médio de acertos passou de 8,57 para 9,21 após a intervenção (de um total de 10 pontos possíveis). Os professores consideraram que o treinamento foi válido e que o material elaborado serviu como base teórica para o desenvolvimento de atividades com as crianças. Os depoimentos dos pais e alunos foram, na maioria, referentes a mudanças positivas ocorridas no comportamento 
alimentar, entretanto, foi relatado que as maiores mudanças foram observadas em períodos próximos à abordagem dos temas de alimentação saudável e que aos poucos os velhos hábitos retornaram. Conclusão: Entre outros aspectos, concluiu-se que o treinamento do professor para a educação nutricional de crianças em idade pré escolar é uma importante estratégia que pode trazer beneficios para toda a comunidade, desde que seja uma atividade contínua.

Descritor: Educação Nutricional; Educação infantil; Capacitação de professores. 


\begin{abstract}
Macedo IC. Training Pre-School and Kindergarten Teachers on Nutrition Education. São Paulo; 2003 [Master's Thesis - Faculdade de Saúde Pública da Universidade de São Paulo].
\end{abstract}

Objective: Nutrition education for children has been the recommended strategy to contain the progress of prevalent non-transmitted chronic diseases. This study was designed to assess a nutrition education training strategy for teachers of a Pre-K-12 private school in the city of São Paulo, Brazil. Methodology: Thirty pre-school and Kindergarten teachers, instructing children between ages 1 and 6 , participated in the study. The research was developed in three distinct phases: 1) Diagnostic evaluation-a survey was administered to assess the depth of teachers' knowledge regarding nutrition and eating habits; 2) Assessment of the impact of the educational intervention upon nutrition knowledge - one year after the educational intervention teachers filled out the same survey administered in the first phase; 3) Assessment of the effects of the educational intervention - the remarks of teachers, children, and parents were used to evaluate the impact of the activities. Educational Intervention: It consisted of a meeting with the teachers (training) utilizing pedagogical material designed to support the educational activities. Results: The study's population consisted of $100 \%$ females with mean age of 35,5 years $(\mathrm{SD}=11,3$ years); the majority $(65 \%)$ with completed undergraduate degrees and $21 \%$ with graduate degrees. Data analysis revealed a significant statistical difference in gain scores regarding nutrition education knowledge after treatment. The mean for correct answers went from 8,57 to 9,21 after treatment (out of possible 10 points). Teachers considered the study to be of value and remarked that the educational materials served as a theoretical basis for the development of children's activities. The comments from parents and students were in the majority regarding the positive changes in the eating behavior; however, the more significant changes were observed around periods closer to the presentation of healthy eating themes. The old eating habits, though, slowly retumed. Conclusion: Among other aspects, the findings for this study show that teachers' training in nutrition education for pre-school and 
Kindergarten children is an important strategy that may benefit the community as a whole as long as it becomes a continuous activity.

Describers: Nutrition Education; Pre-School and Kindergarten Education; Teacher's Training. 


\section{ÍNDICE}

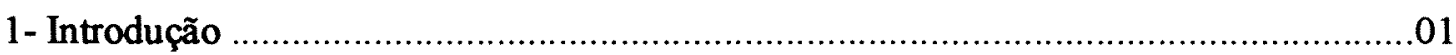

1.1 A importância da educação nutricional ...................................................08

1.2 A importância da escola na educação nutricional ......................................09

1.3 A importância da metodologia para educação nutricional .........................12

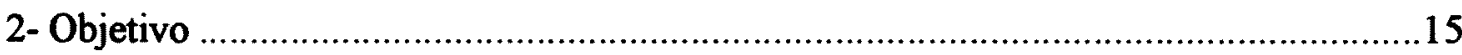

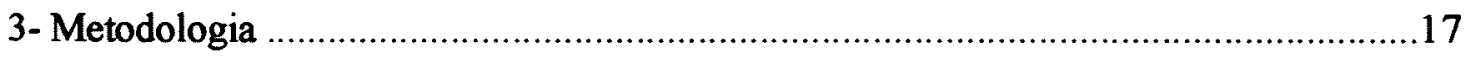

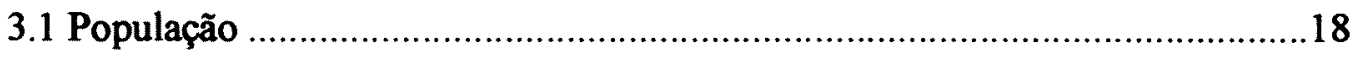

3.2 Desenvolvimento do estudo ……………………………………………......18

3.2.1 Primeira etapa - avaliação diagnóstica …................................18

3.2.2 Segunda etapa - avaliação do impacto da intervenção ..................19

3.2.3 Terceira etapa - avaliação das repercussões .................................20

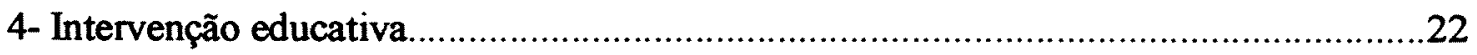

4.1 Desenvolvimento do material didático ................................................23

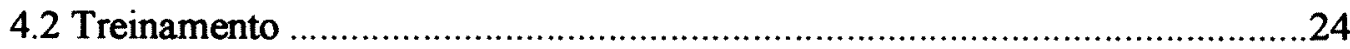

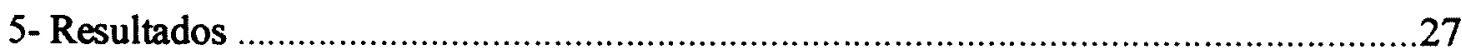

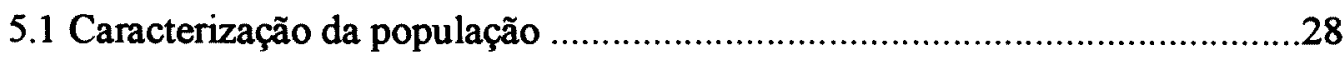

5.2 Conhecimentos sobre alimentação e nutrição ….........................................30

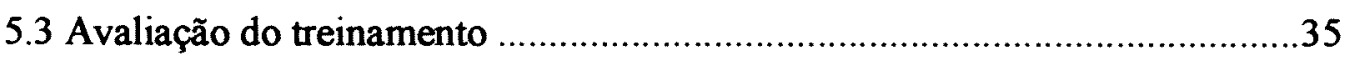

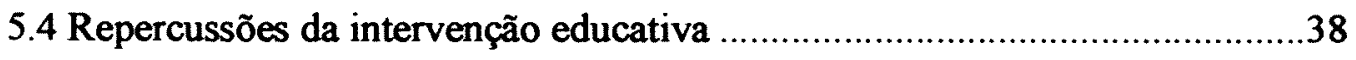

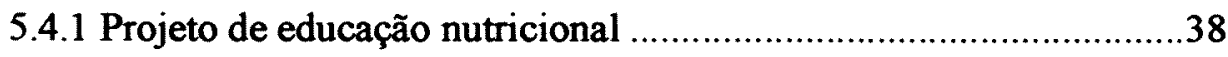

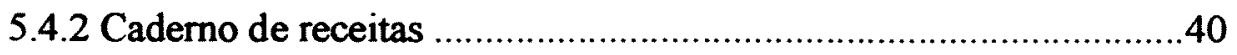

5.4.3 Percepções de mudanças no comportamento alimentar .................43 
6- Discussão

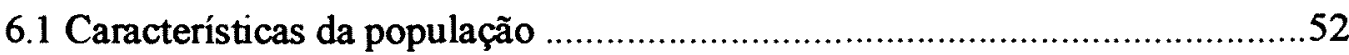

6.2 Impacto da intervenção educativa nos conhecimentos ............................55

6.3 Avaliação da estratégia didática da intervenção educativa .......................58

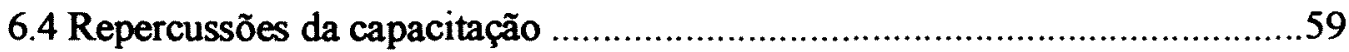

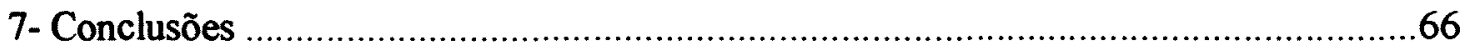

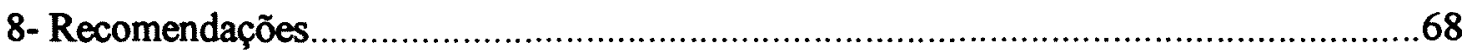

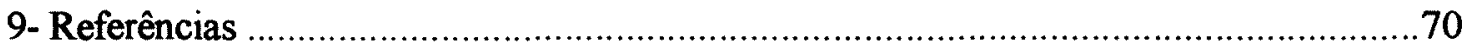

ANEXOS

Anexo 1 Termo de consentimento de participação ..........................................Al

Anexo 2 Ficha de avaliação perfil do educador ...............................................A2

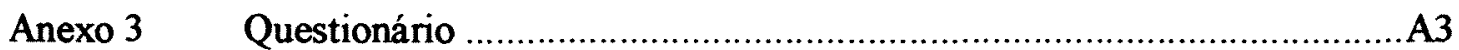

Anexo 4 Ficha de avaliação das atividades relacionadas ao projeto .................. A4

Anexo 5 Guia de nutrição e alimentação para uma vida saudável .......................A5

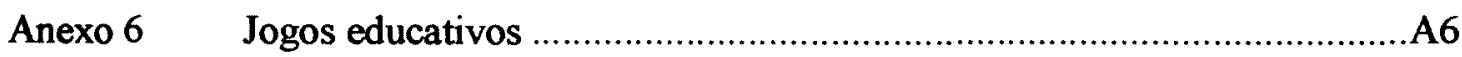

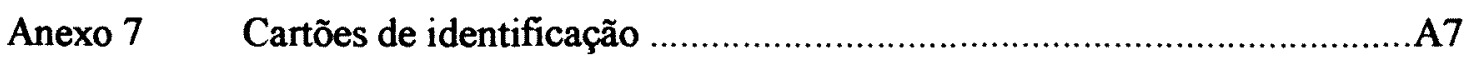

Anexo 8 Lista de alimentos/preparações para cardápio de almoço .....................A8

Anexo 9 Lista de alimentos/preparações para café da manhã ...........................A9

Anexo 10 Texto para discussão - "Obesidade na infância e na adolescência" ......A10

Anexo 11 Apostila de apresentação do projeto ….............................................A11

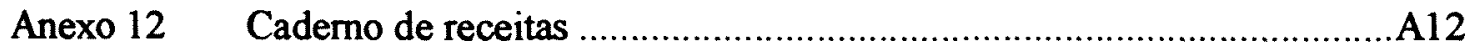




\section{INTRODUCÃO}

É indiscutível a importância da alimentação para o crescimento e desenvolvimento físico humano, especialmente em indivíduos em idade pré-escolar, devido ao acelerado processo de maturidade biológica e de desenvolvimento social e motor (HOLLAND 1999). É na infância que, normalmente, o comportamento alimentar tem as suas bases fixadas. As práticas alimentares são transmitidas pela família, sustentadas pela tradição, crenças, valores e tabus que passam através das gerações (MOTTA e BOOG 1987).

Segundo FISBERG e VÍTOLO (1994), os hábitos alimentares estabelecidos nos primeiros anos de vida poderão influenciar o comportamento em relação a práticas de saúde na idade adulta. Assim, é extremamente importante o modo como as refeições são conduzidas, tanto na qualidade como na quantidade de alimentos oferecidos, bem como no ambiente fisico e emocional que os adultos proporcionam às crianças.

HOLLAND (1999) e FISBERG e VÍTOLO (1994) concordam que as práticas alimentares são reflexos de diversos fatores sociais, econômicos e culturais que estão inter-relacionados. Nesse contexto, a criança absorve modelos e comportamentos adotados pelos adultos presentes na família e na comunidade. RAMOS e STEIN (2000) relatam que no contexto social familiar, muitas vezes, os vegetais são oferecidos às crianças com negatividade. Já alimentos ricos em açúcar, gordura e sal são oferecidos num contexto positivo (premiações, festas, celebrações) potencializando a preferência para esses alimentos. 
Outros fatores influenciam as escolhas alimentares. BIRCH (1980) verificou, em estudo com 128 crianças em idade pré-escolar residentes em Illinois - EUA, que suas escolhas alimentares não foram simplesmente determinadas pelos pais, mas influenciadas pela forma com que os alimentos lhes foram apresentados e pelos alimentos consumidos por heróis da televisão.

BORZEKOMESKI e ROBINSON (2001) sugerem, em seu estudo com 46 crianças residentes na Califórnia - EUA, com idades entre 2 e 6 anos, que as preferências alimentares das crianças também tendem a refletir o que é visto em comerciais de televisão. Segundo os autores, são necessárias apenas uma a duas exposições a comerciais de alimentos para produzir influências em curto prazo nas preferências por alimentos específicos. ALMEIDA, NASCIMENTO e QUAIOTI (2002) analisaram programação de três principais redes de TV de canal aberto no Brasil e constataram que a categoria de maior freqüência de anúncios veiculados pela televisão é a de alimentos, representando aproximadamente $25 \%$ de todas as propagandas. Em análise qualitativa dessas propagandas, comparando-as à Pirâmide Alimentar, $57,8 \%$ estão no grupo de alimentos representados por gorduras, óleos, açúcares e doces e uma completa ausência de frutas e hortaliças, o que faz com que a freqüência de veiculação de alimentos na TV difira significativamente da pirâmide considerada ideal. Essas constatações tornam-se ainda mais preocupantes se considerado o estudo de HOLLAND (1999) que verificou que $90 \%$ das crianças atendidas em creches do município de São Paulo assistem à televisão ao chegar em casa. 
Vários estudos sobre consumo alimentar entre crianças e adolescentes do Brasil e em outros países mostraram dieta desequilibrada em termos de alimentos e nutrientes que podem trazer conseqüências prejudiciais à saúde.

Estudando o consumo alimentar de 208 crianças da primeira série do Ensino Fundamental, em escolas da prefeitura do município de Florianópolis - SC, CALDEIRA (1998) obteve resultados que mostraram consumo excessivo em relação ao grupo de alimentos protéicos e consumo deficitário de alimentos do grupo das frutas e hortaliças. Essa deficiência também foi detectada por HOLLAND (1999) que verificou proporção muito baixa $(4 \%)$ de crianças que consumiam hortaliças no domicílio.

Avaliando o consumo de alimentos industrializados por crianças de 0 a 60 meses, AQUINO (1999) observou precoce introdução desses alimentos na dieta e elevado consumo de alimentos de baixo valor nutritivo, como doces e salgadinhos, principalmente entre as crianças cujas mães trabalhavam fora.

A atração das crianças por alimentos doces foi observada no estudo de TOMITA e col. (1999) com 572 crianças de 4 a 6 anos, que apontaram preferência por solução (água-açúcar) mais doce, sem variação segundo a idade e o sexo.

DOYLE e FELDMAN (1997), avaliando o consumo alimentar, verificaram que adolescentes preferiam salgados fritos e refrigerantes para composição de seus lanches.

Baixa ingestão de frutas, hortaliças e produtos lácteos foi constatada em estudo realizado com 523 estudantes, com idade média de 14 anos, das zonas urbana e rural, cursando a $8^{a}$ série do ensino fundamental (CASTRO 2001). 
Essas características da alimentação têm se manifestado também na população adulta. Isso porque, de modo geral, o brasileiro vem modificando seus hábitos alimentares para um padrão menos adequado.

CERVATO e col. (1997), estudando 557 indivíduos com idade entre 20 e 88 anos, verificaram que apenas $5 \%$ deles apresentaram dieta adequada quanto energia, distribuição calórica e colesterol.

MONTEIRO, MONDINI e COSTA (2000) observaram intensificação do consumo de carnes, leites e derivados (exceto manteiga) em todas as áreas metropolitanas do Brasil, bem como o crescimento da participação relativa de açúcar refinado e refrigerantes. Foi observada também uma tendência ascendente da participação relativa de lipídios na dieta do Norte e Nordeste, o aumento no consumo de gorduras saturadas em todas as áreas metropolitanas do país, ao lado da redução do consumo de carboidratos completos e da estagnação ou redução do consumo de frutas e hortaliças.

De acordo com MONTEIRO, MONDONI, SOUZA e POPKIN (1995), o consumo alimentar da população brasileira tende em direção ao aumento da densidade energética. Os resultados da avaliação do processo de transição nutricional demonstram que o Brasil está substituindo rapidamente o problema da escassez pelo excesso dietético.

Segundo COUTINHO (1998), mudanças na composição de macronutrientes na dieta, associadas a fatores genéticos e ambientais, constituem risco adicional para o desenvolvimento da obesidade, que está se transformando em um problema de saúde pública. 
TROIANO e FLEGAL(1998) relatam que a população dos Estados Unidos apresenta uma proporção de $25 \%$ de crianças e adolescentes com sobrepeso ou risco para obesidade. Segundo o autor, na década de 1970, essa proporção era menor de $5 \%$. Na população brasileira, tanto de renda média quanto alta, os índices de obesidade superam os de desnutrição. Conforme aumenta a renda familiar, decresce a desnutrição e aumenta a obesidade (MONTEIRO, MONDONI, SOUZA e POPKIN 1995).

A obesidade pode trazer consigo agravos à saúde e comprometimento para a qualidade da vida adulta. DIETZ (1998) relata que hiperlipidemias, diabetes, hipertensão, complicações ortopédicas, amadurecimento precoce além da autorejeição e dificuldade de socialização são algumas das conseqüências que crianças obesas podem sofrer ainda na infância.

REGO e col. (1990) apontaram a obesidade como um dos importantes fatores de risco para doenças crônicas não transmissíveis (DCNT). As DCNT representam-se por grupo de doenças caracterizadas por: história natural prolongada; multiplicidade de fatores de risco complexos; interação de fatores etiológicos conhecidos; interação de fatores etiológicos desconhecidos; longo período de latência; longo curso assintomático; curso clínico em geral lento, prolongado e permanente; manifestações clínicas com períodos de remissão e de exacerbação; evolução para graus variados de incapacidade ou para a morte. As DCNT mais freqüentes que não apresentam a participação de microorganismos em suas determinações são: hipertensão arterial, doenças cerebrovasculares, infarto agudo do miocárdio, doenças cardiovasculares, diabetes (LESSA 1998). DRUMOND e 
BARROS (1999) ressaltam a forte participação dessas doenças no padrão de mortalidade do adulto no município de São Paulo nos anos de 1990, 1991 e 1992.

No ano de 1930 , as doenças cardiovasculares foram responsáveis por $11,8 \%$ dos óbitos ocorridos no Brasil. Porém, em 1994 houve um aumento para 33,3\%. As DCNT - infarto agudo do miocárdio, doença cerebrovascular aguda, insuficiência cardíaca e diabetes - foram as principais causas de óbito no país (BARRETO e CARMO 1998).

Estudos epidemiológicos recentes têm evidenciado estreita relação entre as características da qualidade da alimentação e ocorrência de enfermidades crônicas, como as doenças cardiovasculares, o diabetes mellitus tipo II, diferentes tipos de câncer e obesidade (HOLCOMB e col. 1998; AULD e col. 1999). MONTEIRO, IUNES e TORRES (1995) relataram que o consumo de alimentos ricos em gorduras animais e saturadas está fortemente associado à ocorrência de doença coronariana, de câncer de cólon, próstata e mama.

Como prevenção e intervenção no processo de agravos à saúde causados por consumo alimentar inadequado, BIRCH e FISHER (1998) propõem planejamento alimentar baseado nas necessidades energéticas diárias, considerando a história alimentar do indivíduo. Uma intervenção que abranja campanhas para conscientização das crianças para a necessidade de uma alimentação saudável, bem como atividades de relações públicas envolvendo toda a comunidade foram propostas por STEDRONSKY (1998) visando redução dos índices de obesidade abordada por diversos pesquisadores. 
HARRIS (1997) coordenou um projeto de intervenção objetivando a redução de fatores de risco para doenças crônicas. Participaram desse estudo 6400 crianças, professores e pais de alunos. A abordagem envolveu modificação da refeição escolar, educação nutricional e incentivo à atividade física. No campo da educação nutricional, obteve-se um resultado satisfatório comprovado estatisticamente, sugerindo ser esse um método importante no processo de formação de hábito alimentar.

A intervenção por meio de programas de educação nutricional é a sugestão de BOOG (1996) para reverter quadro de desequilibrio do consumo alimentar.

\subsection{A importância da educação nutricional}

Educação nutricional é “uma busca compartilhada entre educador e educando, de novas formas e novos sentidos para o ato de comer, que se processa em determinado tempo e local, através da interação e do diálogo, por meio da qual se almeja a qualidade e a plenitude do viver" (BOOG 1997). Deve criar no educando o desejo de mudar a sua alimentação para promover melhoria da saúde, eliminando práticas alimentares insatisfatórias e utilizando os recursos alimentares de forma mais eficiente, e não apenas transferir informações sobre valor nutritivo ou técnica de preparo do alimento (FISBERG e VÍTOLO 1994; BOOG 1996).

LIMA (1997), após avaliar história e composição da educação nutricional, sugere que seu fundamento consiste em formar bons hábitos alimentares, difundir conhecimentos básicos de alimentação e nutrição, divulgar a importância da nutrição 
para a manutenção da saúde, ensinar a utilização adequada dos alimentos e incentivar o aproveitamento de recursos alimentares regionais.

Segundo UBEDA (1986), o propósito da educação para a saúde é melhorar qualidade de vida do ser humano. Para a consecução efetiva desse objetivo, faz-se necessário o desenvolvimento de um processo educativo contínuo que motive o indivíduo a desenvolver suas potencialidades, capacitando-o a adaptar-se às situações e mudanças que ocorrem durante sua vida, considerando para tanto, aspectos cognitivos, emocionais e comportamentais (BISSOLI e LANZIOLLOTTI 1997).

MONDINI e MONTEIRO (1995), assim como TOMITA e col. (1999) recomendam a implementação de medidas que visem à conscientização para a importância da relação dieta/saúde prioritária, no sentido de garantir a melhoria na qualidade de vida da população.

\subsection{A importância da escola na educação nutricional}

Para UBEDA (1986), a escola tem se mostrado ambiente adequado para a educação nutricional, pois representa o primeiro grupo social depois da família. Nela são criados vários hábitos, inclusive os de saúde. Com seus métodos e técnicas educativas, tem condições de desenvolver o treinamento preciso à formação de hábitos básicos de saúde, modificar ou reforçar hábitos e atitudes dos alunos, a partir daqueles que ele traz (ou não) do lar. Além disso, a escola é uma instituição que pode atingir aqueles que não a freqüentam, pois mantém ramificações e inter-relações com 
os variados setores da comunidade. É capaz de desenvolver programas de educação para a saúde junto aos programas curriculares que efetua.

HOLLAND (1999) constatou que crianças que freqüentam instituições como berçários, creches, escolas maternais, jardins de infância e pré-escolas absorvem valores, atitudes e comportamentos vivenciados nas horas de permanência nesses ambientes, ampliando seus universos.

FOCESI (1990) relata que a função da escola não é simplesmente informar, mas, principalmente criar condições para que o escolar esteja motivado a se educar, colaborando no desenvolvimento das capacidades que lhe permitem atuar como cidadão na luta para a transformação e melhoria de vida. Efetivos programas de educação nutricional nas escolas vêm colaborar na capacitação de crianças e adolescentes, no que se refere às escolhas corretas sobre comportamentos que promovam a saúde, não somente deles, mas também da família.

Para UBEDA (1986), a escola, como instituição educacional e social, deve preocupar-se também em contribuir para que o aluno atinja melhores níveis de saúde, proporcionando-lhe uma vida saudável. Por esse motivo deve estar voltada para o aspecto preventivo, ou seja, para a preservação e promoção da saúde.

Conhecendo o poder de influência da escola, em 1971, a Lei n ${ }^{\circ} 5692$ tornou obrigatória a inclusão dos programas de saúde nas escolas de $1^{\circ}$ e $2^{\circ}$ graus e dispõe que as crianças menores de sete anos recebam conveniente educação em escolas maternais, jardins de infância e instituições equivalentes (BRASIL 1971). Apesar dessa regulamentação, a educação nutricional em currículos escolares pouco tem sido praticada (FISBERG e VÍTOLO 1994). 
Instituição norte-americana (American Dietetic Associantion's - ADA) recomenda a inserção de educação nutricional inserida em programas de cuidado à criança, integrando a alimentação a atividades do ensino de nutrição (ADA 1999).

A educação em saúde na escola precisa ser mais efetiva. Da forma como vem sendo realizada, muitas vezes não promove a saúde da criança, nem tão pouco ajuda o pré-escolar a perceber a importância de medidas básicas de saúde, não o predispondo a agir corretamente em relação a elas, mas, apenas, repassando algumas informações superficiais isoladas entre si e desvinculadas da sociedade geral (UBEDA 1986).

Há de se estar bastante atento quanto às informações direcionadas às crianças. LEVINE e GUSSOW (1999) verificaram, em estudo realizado com 689 profissionais de nutrição, membros da $A D A$ e da Society for Nutrition Education (SNE), que, ao utilizarem material informativo de grandes empresas alimentícias, como Mc Donald's e Coca-Cola, acabavam por incentivar o consumo de alimentos ricos em gordura, sódio e açúcar.

Estudo de caráter qualitativo realizado com alunos completando o último ano do Curso de Magistério (Formação de professores de $1^{\mathrm{a}}$ a $4^{\mathrm{a}}$ série do $1^{\mathrm{o}}$ grau) conclui que o preparo do professor primário não está adequado para transmitir conceitos em Educação para a saúde (BÓGUS, PEREIRA e WESTPHAL 1990).

Uma avaliação sobre as informações veiculadas por livros didáticos utilizados no Ensino Fundamental brasileiro observou que, além de desatualizados, os conceitos sobre alimentação e necessidades nutricionais fornecem informações incompletas sobre o papel da dieta na prevenção de doenças crônicas não 
transmissíveis (GAGLIONE 1999). Tal fato já havia sido constatado por FOCESI (1990) que afirmou que professores dos cursos de Formação para o Magistério ou de Faculdades de Educação, recebiam pouca orientação sobre saúde pública ou Educação em Saúde.

Conhecedora dessa deficiência, RONCADA (1992) propôs que o professor escolar participasse de treinamento promovido por nutricionista, no qual recebesse orientação para estabelecer condições criativas e significativas interações crianças/alimentos.

A fím de evitar divergências, LEVINE (1999) propôs a elaboração de guias para a educação em saúde a ser utilizado pela escola, a fim de uniformizar a informação. Também sugeriu que todo material a ser veiculado nas escolas, inclusive informes publicitários, sofresse triagem exercida pelo nutricionista antes de ser exposto aos alunos.

\subsection{A importancia da metodologia para educação nutricional}

A criança em idade pré-escolar encontra-se em fase de intensas descobertas como as de conhecer o próprio corpo e as possibilidades de seus movimentos, interagir com os outros e se comunicar. Por isso, a educação nessa fase requer planos de ensino que respeitem suas peculiaridades e funções (MICOTTI 1994).

A metodologia educacional pode ser ineficaz se não estiver adequada ao modo de aprender da criança (LOPES 2001). Para ANTUNES (2000), o ambiente afetuoso e a educação rica em estímulos constituem fatores essenciais ao aprendizado 
da criança. Jogos e brinquedos educativos têm sido indicados como recursos estimuladores para o desenvolvimento de aspectos cognitivos, afetivos e sociais, podendo assumir função lúdica e educativa pois propicia diversão e ensinamentos, completando o indivíduo em seu saber, conhecimentos e apreensão do mundo (KUHLMANN 2000; KISHIMOTO 2001). Nesse sentido, a educação nutricional para as crianças de menor idade escolar deve ser introduzida por meio do ensino incidental em todas as oportunidades ou momentos com implicações de saúde durante as rotinas diárias, reconhecendo a dinâmica do prazer e desprazer na alimentação (UBEDA 1986). Entretanto, foi demonstrado que estratégias que utilizam apelos às ameaças oferecem resultado negativo. FISBERG e VÍTOLO (1994) recomendam a opção por modelos de ensino que explorem os apelos às vantagens e beneficios do objeto estudado.

Um programa de educação nutricional baseado na teoria das inteligências múltiplas* $^{*}$ realizado com crianças de 36 e 67 meses de idade, utilizou recursos didáticos como estónias, livros, cassetes, vídeos, aulas de culinária, jogos, pôsteres, computadores, degustação, músicas, quebra-cabeça, projetos artísticos e fantoches. Ao término do processo de intervenção educativa, as crianças estavam mais aptas a identificarem os alimentos e suas funções. Também aumentaram o consumo de frutas, hortaliças, carnes, produtos lácteos e pães e diminuíram a ingestão de alimentos gordurosos, óleos e doces concentrados, tomando a dieta mais saudável (CASON 2001).

- Teoria das Inteligências Miltiplas - convição de Howard Garcher e de uma grande equipe da Universidade de Haward de que o ser humano é dotado de inteligéncias múltiplas que inctuem dimensöes ingüística, lógicomatemática, espacial, musical, cinestésico-corporal, naturalista, intapessoal, interpessoal e pictórica (esta última, acrescentada pelo Prof. Nilson José Machado, doutor em Educaçāo pela Universidade de Sáo Paulo) (ANTUNES 2000). 
CORNACCHIA, OLSEN e NICKERSON (1988) propuseram aplicação de aulas de culinária, horta didática e feiras educativas como recursos para educação nutricional. Para complementar o processo, FISBERG e VÍTOLO (1994) sugeriram a utilização de técnicas e recursos audiovisuais como álbum seriado, fantoches, teatro, jogos educativos, canções e narração de estórias que permitiriam conduzir o educando a observar, experimentar, comparar, concluir, transferir a aprendizagem e finalmente agir.

É importante ressaltar que o processo de introdução ou modificação de hábitos alimentares precisa ser efetuado de forma muito cautelosa, muito bem planejado e organizado, pois as ações realizadas podem interferir intensamente na rotina familiar (HOLLAND 1999).

Pelo exposto, verifica-se a necessidade de desenvolver projetos de educação nutricional em escola de educação infantil, objeto de avaliação do presente trabalho. 
2. OBJETIVO 


\section{OBJETIVO}

Avaliar uma estratégia de capacitação para educação nutricional dirigida a professores de um curso de educação infantil de uma escola da rede particular de ensino do município de São Paulo. 
3. METODOLOGIA 


\section{METODOLOGIA}

\subsection{População}

A população de estudo foi composta por educadores de crianças do setor de Educação Infantil de uma escola da rede particular de ensino no município de São Paulo. Esse setor atende crianças nos períodos da manhã e tarde, com idades entre $1 \mathrm{e}$ 6 anos, divididas em classes de acordo com a faixa etária.

A participação na pesquisa foi voluntária. Os educadores receberam um termo de consentimento livre em que se esclareciam objetivos, beneficios, riscos, métodos, sigilo e possibilidade de desistência de participar do estudo (ANEXO 1).

\subsection{Desenvolvimento do Estudo}

A pesquisa foi realizada em três etapas. A primeira referiu-se à avaliação diagnóstica do grau de conhecimento dos professores sobre alimentação e nutrição. A segunda foi a avaliação do impacto da intervenção educativa nos conhecimentos sobre nutrição entre os professores. A terceira etapa referiu-se à avaliação das repercussões decorrentes da intervenção educativa.

\subsection{1 - Primeira etapa - avaliação diagnóstica}

Essa etapa foi realizada no primeiro trimestre do ano de dois mil e um. 
A participação ativa da coordenadora do curso de educação infantil foi de fundamental importância para a viabilização do contato pessoal com todos os professores, pois promoveu os encontros com duração de 20 minutos, nos períodos da manhã e da tarde em dois dias consecutivos, nos quais foram possíveis as orientações aos professores sobre as atividades referentes ao desenvolvimento do projeto.

Solicitou-se aos professores o preenchimento da ficha Perfil da População (ANEXO 2) e que respondessem ao questionário que visava avaliar o grau de conhecimento em relação aos temas sobre alimentos e nutrientes (ANEXO 3).

Os professores foram orientados a responder o questionário (ANEXO 3) de forma individual, sem consultar qualquer outro material ou pessoa presente na sala. $O$ questionário contendo dez questões objetivas foi desenvolvido baseado na literatura, compreendendo um conjunto de temas que tiveram seu conteúdo transformado em perguntas relacionadas a: alimentos e nutrientes (perguntas 1, 2, 3 e 4), necessidades nutricionais (perguntas 5, 6 e 7) e hábitos alimentares (perguntas 8,9 e 10), tendo como resposta correta apenas uma das cinco alternativas apresentadas.

\subsection{2 - Segunda Etapa - avaliação do impacto da intervenção educativa nos conhecimentos sobre nutrição}

Doze meses após a intervenção educativa, os educadores responderam ao mesmo questionário (ANEXO 3) aplicado na primeira fase, utilizando-se o mesmo procedimento adotado. Ou seja, os educadores foram convocados pela coordenadora do curso a comparecerem à sala de reuniões. Dois a dois, estiveram reunidos com a 
pesquisadora e responderam ao questionário e a ficha de avaliação (ANEXO 4). Foram orientados a responderem individualmente ao questionário, sem consultar qualquer material ou outra pessoa presente na sala. Num total de 12 reuniões de aproximadamente 25 minutos de duração, nos períodos da manhã e tarde, em dois dias consecutivos, foi possível contatar toda a população de estudo.

Para avaliar mudanças no conhecimento, confrontaram-se os resultados da primeira aplicação do questionário com os da segunda. Foi analisada a diferença entre a média do valor inicial (antes da intervenção) e a média do valor final (após a intervenção), empregando-se o teste $t$ de Student para dados pareados, com nível de significância 5\% (DAWSON-SAUNDERS e TRAPP 1994).

\subsection{3 - Terceira Etapa - avaliação das repercussões da intervenção educativa}

Com base no programa de intervenção educativa, os professores tiveram como tarefa a elaboração de um conjunto de ações relacionadas à educação nutricional para serem aplicadas às crianças. Esse projeto foi recomendado pela coordenação da escola, com participação dos professores e nutricionista. O resultado dessas ações foi denominado "Projeto de educação nutricional para uma vida saudável".

Para avaliar a percepção individual obtida em relação ao programa de capacitação, material desenvolvido e demais atividades realizadas com enfoque ao Projeto de Educação Nutricional, solicitou-se o preenchimento de uma ficha contendo perguntas objetivas e subjetivas que abordaram os seguintes temas: treinamento, 
"Guia de alimentação para uma vida saudável", caderno de receitas presenteado às mães e mudança de comportamento em relação à alimentação dos alunos (ANEXO 4).

Considerou-se também a opinião dos pais sobre o projeto. Em reuniões periódicas com pais de alunos, é procedimento comum dos mesmos preencherem uma ficha de avaliação do curso de Educação Infantil. Ao responderem a pergunta “Como você observa o retorno de seu (sua) filho (a) em relação ao que vivencia na escola?", alguns pais fizerem ressalvas a comportamentos e comentários que os filhos levaram para casa, em decorrência da discussão sobre alimentação saudável. Esses apontamentos foram considerados nos resultados dessa dissertação. 
4. INTERVENÇÃO EDUCATIVA 


\section{INTERVENCÃO EDUCATIVA}

A intervenção educativa, ou programa de capacitação, realizou-se no primeiro trimestre do ano de dois mil e um. Foi conduzido encontro com os professores (treinamento) utilizando, como instrumento, material didático para servir de apoio às atividades educativas.

\section{1-Desenvolvimento do material didático}

Foi elaborada uma apostila em forma de livreto intitulada: "Guia de Alimentação e Nutrição para Uma Vida Saudável" (ANEXO 5). Optou-se pelo uso de linguagem simples e de fácil compreensão e recursos visuais. $O$ texto foi elaborado com base na literatura relacionada à alimentação e nutrição. Cada professor recebeu um exemplar da apostila. Uma vez que a coordenação do curso de Educação Infantil considerou que o conteúdo teórico do material poderia ser útil e importante para os outros segmentos da instituição (Ensino Fundamental e Ensino Médio), estendeu-se a distribuição da apostila aos outros coordenadores de cursos e direção da escola.

No sentido de estimular o corpo docente a discutir com seus alunos termos relacionados a alimentos e nutrientes, foi proposto o desenvolvimento de jogos educativos (ANEXO 6) por meio dos quais as crianças pudessem aprender brincando. 


\section{2-Treinamento}

O treinamento oferecido aos educadores realizou-se na própria escola. Os professores foram convocados para o encontro, sendo-lhes informados que o treinamento iniciaria uma série de atividades que fariam parte de um projeto a ser desenvolvido no curso de Educação Infantil no segundo trimestre do ano letivo de dois mil e um.

No encontro, que teve duração de 4 horas, estavam presentes 28 educadores. A estratégia didática para o treinamento foi a aplicação de jogos e dinâmicas em grupos.

Os participantes foram esclarecidos quanto aos objetivos do encontro, enfatizando o papel do professor no processo educacional para formação integral da criança. Ressaltou-se a importância de considerar as características individuais relacionadas às necessidades nutricionais. A dinâmica aplicada para a fixação deste conteúdo foi a ilustração de uma boneca de brinquedo e sua roupinha, associando adequação às necessidades. Houve oportunidade para comentários e perguntas.

Cada professor recebeu um cartão identificado por figuras de vegetais (ANEXO 7): maçã, banana, uva, laranja e berinjela.

Propôs-se aos professores que formassem grupos a partir dos cartões com mesma identificação. Dessa forma, obteve-se 5 grupos que foram assim denominados: Maçãs Vermelhas, Bananas Amarelas, Uvas Verdes, Laranjas Laranjas

e Berinjelas Roxas. Os educadores se agruparam e a cada grupo foi entregue um 
envelope contendo uma tarefa que deveriam executar, justificando-a. Os grupos tiveram um período de 30 minutos para essa atividade.

As atividades propostas foram as seguintes:

"Maçãs Vermelhas" -Elaborar uma proposta de cardápio para um almoço equilibrado contendo 6 alimentos ou preparações, tendo como base uma lista com o nome de 20 alimentos ou preparações (ANEXO 8). O grupo selecionou as seguintes preparações: arroz, feijão, carne assada, bolinho de legumes (frito), salada de folhas e creme de milho.

"Bananas Amarelas" - Elaborar uma proposta de cardápio para um café da manhã equilibrado contendo 6 alimentos ou preparações, tendo como base uma lista com o nome de 20 alimentos ou preparações (ANEXO 9). O grupo selecionou as seguintes preparações: pão, presunto, queijo, suco de frutas, leite com chocolate e cereais.

"Uvas Verdes" - A este grupo, foi solicitado que, numa exposição de alimentos industrializados, selecionassem aqueles ricos em carboidratos. Após essa seleção, deveriam proceder a leitura e interpretação das informações trazidas nos rótulos, além de comparar a composição nutricional dos alimentos, tendo o grupo selecionado: biscoito doce, biscoito salgado, arroz, macarrão, farinha de trigo.

“Laranjas Laranjas" - Procedeu-se da mesma forma utilizada para "Uvas Verdes", apenas solicitando a seleção de alimentos ricos em gordura. Após a seleção, deveriam 
proceder a leitura e interpretação das informações trazidas nos rótulos, bem como comparação entre a composição nutricional dos alimentos. O grupo selecionou os seguintes alimentos: margarina, margarina light, óleo de soja, óleo de girassol e óleo de oliva.

“Berinjelas Roxas" - Fazer a leitura de um texto sobre obesidade na infância (ANEXO 10), destacando os itens mais marcantes e relevantes para a discussão.

O segundo momento do treinamento foi a apresentação dos resultados por parte dos grupos. Com base na exposição, pôde-se enfocar temas como: alimentação equilibrada, importância da variedade de alimentos a serem ingeridos diariamente, formação de hábitos alimentares, alimentos industrializados, épocas da produção de alimentos, diferença entre alimentos diet e light, importância de se conhecer a população antes de determinar um padrão alimentar, interação alimentos/corpo humano, doenças relacionadas a hábitos alimentares inadequados, obesidade entre crianças.

Foi oferecido aos professores um material cujo objetivo era servir de apoio para consultar informações básicas sobre alimentação e nutrição - o "Guia de Alimentação e Nutrição para uma Vida Saudável" (ANEXO 5). Os professores foram informados quanto à utilização e leitura das curvas de crescimento para meninos e meninas.

Dentro do contexto, o treinamento foi totalmente cercado por uma dinâmica de troca de idéias e experiências onde todos os participantes interagiam entre si. 
5. RESULTADOS 


\section{RESULTADOS}

\section{1 - Caracterização da População}

No início da pesquisa, a população era composta de 30 educadores. Destes, 28 permaneceram até a etapa final do projeto. Uma funcionária foi dispensada da instituição e outra estava em período de licença maternidade, havendo uma perda de $6,7 \%$ da população inicial.

$\mathrm{Na}$ população estudada, identificaram-se 4 grupos distintos, segundo sua atuação escolar: professores titulares, professores de aulas especiais (música, artes, educação física e religião), auxiliares de ensino e coordenadores de curso, sendo composta em $100 \%$ pelo sexo feminino.

O grupo de professores titulares compreendeu a maioria da população $(57,14 \%)$ e o grupo de coordenadores de curso foi composto por 2 indivíduos $(7,14 \%)$. O número de pesquisados segundo grupos de atividades escolares está especificado na TABELA 1. 
TABELA 1 - Distribuição da população estudada, segundo grupo de atividade escolar. São Paulo, 2001.

\begin{tabular}{lcc}
\hline GRUPO DE ATIVIDADE & \multicolumn{2}{c}{ NUMERO DE INDIVIDUOS } \\
ESCOLAR & No & $\%$ \\
\hline Professores titulares & 16 & 57,14 \\
Professores de aulas especiais & 6 & 21,43 \\
Auxiliares de ensino & 4 & 14,29 \\
Coordenadores de curso & 2 & 7,14 \\
TOTAL & 28 & 100,00 \\
\hline
\end{tabular}

Os professores titulares são responsáveis diretos pela classe, e a eles cabe a escolha das atividades a serem desenvolvidas pelos alunos, dentro do padrão determinado pela coordenação do curso. A atuação dos professores de aulas especiais está relacionada a diferentes atividades (música, artes, educação fisica e educação cristã). A atuação dos auxiliares de ensino está subordinada aos professores titulares.

A média de idade da população estudada foi de 35,3 anos (desvio padrão = 11,30 anos) variando de 25 a 52 anos. Conforme se observa na FIGURA 1, 65\% dos educadores possuíam curso superior completo. Destes, $21 \%$ possuíam curso de pósgraduação em Psicopedagogia. 
FIGURA 1 - Distribuição relativa da população estudada, segundo formação acadêmica,

São Paulo, 2001

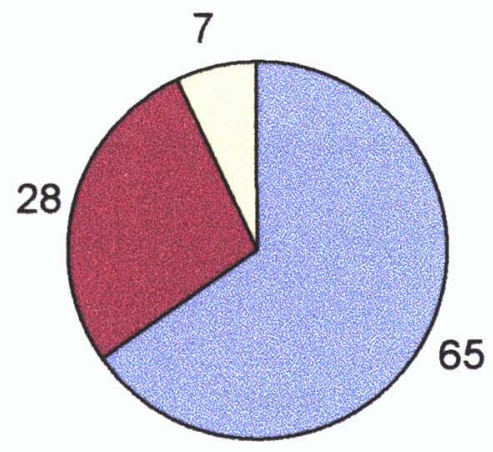

$\square$ curso superior completo $\square$ cursando superior

$\square$ magistério (ensino médio)

O curso que apresentou maior freqüência entre a população estudada foi o de Pedagogia $(46,43 \%)$, sendo que havia 3 professores em fase de estudos.

\section{2- Conhecimentos sobre alimentação e nutrição - avaliação dos resultados antes e após intervenção educativa}

O questionário composto por 10 perguntas de múltiplas escolhas, contendo apenas uma alternativa correta, foi aplicado aos professores de todas as áreas. Participaram da primeira fase, 30 educadores.

A média geral da avaliação de conhecimento antes da capacitação, realizada em março de 2001, foi de 8,57 (desvio padrão $=0,10$ acertos) de um total de 10 pontos possíveis, variando de 0,0 a 10,0 . Na avaliação de conhecimento pós- 
capacitação, realizada em abril de 2002 , o número médio de respostas corretas foi de 9,21 (desvio padrão $=0,07$ acertos). Comparando-se os resultados obtidos das duas fases, observou-se uma diferença estatística significativa de 0,64 ponto. Esses resultados podem ser observados na TABELA 2.

Para todas as questões, exceto as de número 2 e 9 , a análise revelou efeito significante.

TABELA 2 - Distribuição das médias das pontuações do conhecimento sobre alimentação e nutrição, antes e após treinamento, São Paulo, 2002.

\begin{tabular}{cccccc}
\hline & $\begin{array}{c}\text { Anterior à } \\
\text { capacitação }\end{array}$ & \multicolumn{5}{c}{$\begin{array}{c}\text { Posterior à } \\
\text { capacitação }\end{array}$} \\
\hline Questōes & $\begin{array}{c}\text { Média de } \\
\text { Acertos }^{(-1)}\end{array}$ & $\begin{array}{c}\text { desvio } \\
\text { padrão }\end{array}$ & $\begin{array}{c}\text { Média de } \\
\text { acertos }\end{array}$ & $\begin{array}{c}\text { desvio } \\
\text { padrão }\end{array}$ & P('2) $^{(2)}$ \\
\hline $\mathbf{1}$ & 0,80 & 0,41 & 0,89 & 0,31 & 0,000 \\
$\mathbf{2}$ & 1,00 & 0,00 & 1,00 & 0,00 & - \\
$\mathbf{3}$ & 0,67 & 0,48 & 0,86 & 0,36 & 0,000 \\
$\mathbf{4}$ & 0,87 & 0,35 & 0,75 & 0,44 & 0,000 \\
$\mathbf{5}$ & 0,73 & 0,45 & 0,96 & 0,19 & 0,000 \\
$\mathbf{6}$ & 0,90 & 0,31 & 0,93 & 0,26 & 0,000 \\
$\mathbf{7}$ & 0,87 & 0,35 & 0,93 & 0,26 & 0,000 \\
$\mathbf{8}$ & 0,87 & 0,35 & 0,96 & 0,19 & 0,000 \\
$\mathbf{9}$ & $\mathbf{0 , 9 7}$ & 0,18 & 0,97 & 0,18 & - \\
$\mathbf{1 0}$ & $\mathbf{0 , 8 9}$ & $\mathbf{0 , 3 1}$ & 0,96 & 0,19 & 0,000 \\
\hline Total & $\mathbf{8 , 5 7}$ & $\mathbf{0 , 1}$ & $\mathbf{9 , 2 1}$ & $\mathbf{0 , 0 7}$ & $\mathbf{0 , 0 0 0}$ \\
\hline
\end{tabular}

(*1) Para cada questão, o valor máximo esperado era 1 (um) e o mínimo, 0 (zero)

$(* 2) \mathrm{p}<0,001$

A questão 1, referente a definição de nutrientes, foi respondida corretamente por $80,0 \%$ dos professores, apresentando uma média de acertos de 0,80 (desvio padrão $=0,41)$ na primeira fase. Na segunda fase, $89,3 \%$ respondeu corretamente, com média de acertos 0,89 (desvio padrão $=0,31$ ). Analisando os dados 
individualmente, 6 professores que haviam respondido de forma errada na primeira fase, passaram a responder corretamente. Entretanto, 3 pessoas que haviam acertado na primeira fase, responderam errado na segunda.

Para a questão 2, referente aos nutrientes fundamentais ao organismo, $100,0 \%$ da população estudada respondeu corretamente - média de acertos 1,0 (desvio padrão $=0,0)$ tanto na primeira fase quanto na segunda. Para este resultado, não houve variância.

A questão 3, que trazia abordagem sobre alimentos energéticos, foi respondida corretamente por $66,7 \%$ dos professores na primeira fase, com média de acerto de 0,67 (desvio padrão $=0,48$ ) e na segunda fase, a proporção de acertos foi de $85,7 \%$, com média 0,86 (desvio padrão $=0,36$ ). A análise individual dos dados permite constatar que 7 pessoas que haviam respondido errado na primeira fase responderam corretamente na segunda; 3 mudaram suas respostas para outra alternativa igualmente errada e 1 professor passou a responder errado na segunda fase, tendo acertado na primeira.

Referente à questão 4 , houve uma diminuição na freqüência de acertos. A proporção de acertos na fase anterior à capacitação foi maior do que na fase posterior. Essa questão era referente às vitaminas e minerais e foi respondida corretamente por $86,7 \%$ dos indivíduos na primeira fase, com média de acertos de 0,87 (desvio padrão $=0,35$ ). Já na segunda fase, $75,0 \%$ respondeu corretamente, com média de 0,75 (desvio padrão $=0,44)$. Dos professores que haviam errado na primeira fase, 2 mantiveram suas respostas erradas na mesma alternativa e 2 passaram a responder 
corretamente. No entanto, 5 professores que haviam acertado mudaram suas respostas para alternativas não corretas.

A questão 5 abordou a alimentação saudável e foi respondida corretamente por $73,3 \%$ na primeira fase, com média de acertos de 0,73 (desvio padrão $=0,45)$. $\mathrm{Na}$ segunda fase, a proporção de acertos foi de $96,4 \%$, com média de 0,96 (desvio padrão $=0,19$ ). Apenas 1 professor manteve a resposta errada, sendo que 7 deles mudaram suas respostas para a alternativa correta. Essa foi a questão que apresentou a maior diferença entre as médias do teste anterior e posterior à intervenção educativa.

Para a questão 6 , referente às necessidades nutricionais, a proporção de respostas corretas no teste antes da intervenção foi de $90,0 \%$ com média de 0,90 (desvio padrão $=0,31$ ). Após a capacitação, 92,9\% dos professores responderam corretamente, com média de 0,93 (desvio padrão $=0,26$ ). Dentre os 3 professores que erraram, todos mudaram para a alternativa correta na segunda fase. No entanto, 2 dos que haviam respondido corretamente passaram para uma das alternativas erradas, que foi a mesma respondida pelos que erraram na primeira fase.

Abordando a alimentação importante para as crianças, a questão 7 foi respondida corretamente por $86,7 \%$ dos professores na primeira fase do teste, com média de 0,87 (desvio padrão $=0,35$ ), passando para $92,9 \%$ de respostas corretas na segunda fase, com média de 0,93 (desvio padrão $=0,26$ ). Mantiveram a alternativa errada, 2 professores e outros 2 passaram a responder corretamente.

A questão 8, cuja abordagem foi sobre doenças relacionadas ao consumo alimentar, foi respondida corretamente por $86,7 \%$ dos professores na primeira fase, com média de 0,87 (desvio padrão $=0,35$ ) e no teste posterior à intervenção, a 
proporção de acertos foi de $96,4 \%$, com média de 0,96 (desvio padrão $=0,19$ ). Apenas um professor manteve a resposta errada e outros 3 alteraram suas respostas para a alternativa correta.

A questão 9 abordou o tema de hábitos alimentares. Para essa questão, não houve variância entre resultados obtidos nas duas fases. A média de acerto foi de 0,97 (desvio padrão $=0,18)$. $O$ indivíduo que assinalou a questão errada manteve sua resposta na segunda fase.

A última questão foi respondida corretamente por $90,0 \%$ dos professores na primeira fase, com média de 0,89 (desvio padrão $=0,31$ ). Já no teste posterior à intervenção, a proporção de acertos foi de $96,4 \%$, com média de 0,96 (desvio padrão $=0,19$ ). Dentre os professores que haviam respondido erradamente na primeira fase, 1 manteve sua resposta e outros dois alteraram para a alternativa correta.

Ao responderem as perguntas $1,3,4,6$, alguns dos professores que haviam respondido corretamente na primeira fase, mudaram suas respostas para a alternativa errada na segunda fase. Alguns pesquisados mantiveram as mesmas respostas erradas nas duas fases das perguntas $3,4,5,7,8,9$ e 10 . A maior incidência de manutenção do erro foi na questão de número 3 ( 3 individuos), seguido de 2 professores para a resposta de número 4 e 7 e 1 professor para cada uma das outras questões. 


\section{3 - Avaliação do treinamento e do uso do material - percepção dos educadores}

A ficha de avaliação das atividades relacionadas ao programa de capacitação e ao projeto de educação nutricional foi preenchida por 26 professores $(92,9 \%)$ do número final de participantes da pesquisa.

Quanto ao treinamento, $100 \%$ dos participantes concordaram que o mesmo foi dirigido de forma clara e objetiva.

A maioria $(65,4 \%)$ fez comentário sobre a pergunta de número dois: "Houve alguma atividade, conceito ou informação que mais tenha chamado a sua atenção?" Os depoimentos mais freqüentes foram sobre a importância do equilíbrio na alimentação para viabilizar o atendimento das necessidades nutricionais dos diferentes individuos. Os comentários foram os seguintes:

"Na atividade para montarmos um cardápio, para mim chamou a atenção que ainda temos muitas dúvidas para associarmos e combinarmos os alimentos".

"Passei a observar mais a composição dos alimentos que consumo nas embalagens, principalmente em relação à gordura (origem vegetal, animal, etc)".

"A necessidade de observar as características dos produtos (alimentos), para os fins desejados". 
"Para ficarmos mais atentos nas informações das embalagens"

"Foi interessante participar do projeto de modo geral, pois no dia a dia às vezes misturamos os diferentes tipos de alimentos (construtores, energéticos e reguladores)".

"Quando falou sobre as gorduras (tirou nossas dúvidas)"

“Quanto ao valor calórico nos rótulos e embalagens, ou seja, análise de cada alimento"

"Gostei do bolo de chocolate feito com figado"

"Informações quanto ao preparo de alguns alimentos"

"Valor calórico dos alimentos"

"Com relação a montar um cardápio"

"A importância de uma alimentação nutritiva" 
“A avaliação da composição nutricional dos alimentos"

"A importância de uma alimentação balanceada $e$ equilibrada"

"Informações sobre as classes de alimentos e como equilibrar o consumo de cada uma"

"Que a alimentação, necessidades variam de pessoa para pessoa".

Doze meses após a intervenção, $96,2 \%$ dos educadores ainda possuíam o “Guia de alimentação para uma vida saudável". Um educador relatou não o possuir mais por tê-lo presenteado a outra pessoa.

Para 92,4\% dos pesquisados, o “Guia" foi de fácil compreensão. Uma pessoa $(3,8 \%)$ considerou o "Guia" de média compreensão e outra não opinou. Não houve comentários para esta questão.

Dezenove pessoas $(73,1 \%)$ utilizaram o "Guia de alimentação para uma vida saudável" como base teórica para elaborar atividades que foram desenvolvidas com alunos. 


\section{4-Repercussöes da intervençäo educativa}

A intervenção educativa foi o marco inicial para o desenvolvimento de atividades realizadas pela escola, envolvendo professores, pais e alunos, com objetivo de promover melhora na qualidade alimentar das crianças.

\subsection{1 - Projeto de educação nutricional para uma vida saudável}

O "Projeto de educação nutricional para uma vida saudável" (ANEXO 11) é o resultado de um conjunto de idéias e ações para a educação nutricional das crianças. Os educadores elaboraram o Projeto com base nos conhecimentos adquiridos na intervenção educativa. Sugeriram diversas atividades como a elaboração de cardápios juntamente com as crianças e jogos relacionados aos grupos de alimentos.

Os comentários sobre quais atividades desenvolveram, utilizando o Guia como base teórica, foram os seguintes:

“Em todas, de maneira geral, pois ali havia uma boa base teórica"

“Com as crianças, montamos um 'Cardápio equilibrado'

e um painel muito interessante sobre alimentos energéticos, construtores e reguladores" 
"Valor nutricional e preparo de alimentos"

“Alimentação nutritiva. Preparo de salada verde, salada de fruta, etc."

"Ensinei versos e canções sobre alimentação saudável"

"Uso no dia a dia com os alunos"

"Para montar o projeto de nutrição"

"Não exatamente no CBB; utilizei com os alunos do CEFAM na rede estadual"

"Sobre a conservação dos alimentos"

“O Projeto da 'Mostra do Conhecimento' foi todo fundamentado no Guia de alimentação"

"Confeccionamos cardápios com dicas para os pais" 
"Tudo girou em torno dos grupos alimentares e seus efeitos e necessidades na formação, manutenção $e$ equilibrio do corpo"

\subsection{2 - Caderno de receitas}

Foi proposto o desenvolvimento de um "Caderno de Receitas" (ANEXO 12) presenteado às famílias das crianças da Educação Infantil em comemoração ao Dia das Mães. Nesse processo, foi possível o envolvimento das crianças, que confeccionaram a capa do Caderno utilizando recursos técnicos fornecidos pela professora de artes. O Caderno é composto por 27 receitas doces e salgadas, incluindo bebidas, de fácil preparo e custo acessivel. A idéia foi de que as mães recebessem sugestões de alimentos nutritivos que pudessem preparar para as crianças, ou juntamente com as crianças, e, inclusive, enviar no lanche escolar. As receitas são apresentadas em linguagem de fácil compreensão, contém figuras e valor nutritivo de cada receita.

Para $80,8 \%$ dos educadores, o caderno de receitas foi um recurso que colaborou para o envolvimento dos pais no Projeto de educação nutricional realizado pela escola. A maioria dos pesquisados $(61,5 \%)$ comentou sobre a reação dos pais ao caderno de receitas. De um modo geral, os pais elogiaram muito e desenvolveram receitas para serem consumidas no lanche das crianças e também para preparar nas refeições em casa, juntamente com os filhos. Sobre essa questão, os professores fizeram os seguintes comentários: 
"Muitos mandaram o bolo de chocolate e de cenoura no lanchinho dos filhos"

"Todos gostaram muito"

"Sim, de alguns pais. Principalmente das sugestões de alimentação para inserir alguns tipos de alimentos que seus filhos não comem".

"Alguns colocaram que aproveitaram para fazer algumas receitas junto com os filhos"

“Algumas mães fizeram as receitas, as crianças comentaram".

"Apenas que gostaram"

"Só que eles gostaram"

"Os pais gostaram bastante"

"Sim, os pais gostaram muito" 
"Os pais elogiaram"

"Sim, muitas mães fizeram elogios"

"Uso até hoje na minha casa"

"Acredito que sim"

"Os pais não comentaram sobre o caderno de receitas"

"Gostaram e utilizaram as receitas para compor o

lanche"

"Nos finais de semana preparavam pratos e também

traziam no lanche"

“Eles gostaram muito”

"Gostaram muito, comentaram, trouxeram alimentos

feitos no lanche" 


\subsection{3 - Percepções de mudanças no comportamento alimentar das crianças}

Quanto à percepção sobre a intenção ou mudança no comportamento em relação a alimentação das crianças após o Projeto de educação nutricional, 76,9\% dos professores afirmaram ter sido perceptível. Os depoimentos mais freqüentes dos pais foram de surpresa por constatarem que os filhos estavam interessados numa alimentação mais saudável, demonstrando interesse e curiosidade para degustarem novos sabores.

"Muitos pais nos procuraram para dizer que seus filhos estavam comendo frutas e verduras que outrora recusavam"

"Começaram a mandar mais frutas e sempre comentavam sobre sua alimentação em casa. Também começaram a evitar o Mc Donald 's e escovar mais os dentinhos"

"Eles gostaram e disseram que gostariam de estar mandando os lanches de seus filhos de forma balanceada"

"Os pais comentaram isso com as professoras (lembro-me de alguém que falou que seu filho falava:Mãe, isso tem vitamina?' antes de comer algo)" 
"Houve manifestação de interesse em fazer o bolo de figado"

"Os pais pedem sempre orientação quanto ao lanchinho das crianças"

"Estão mais preocupados com a alimentação dos filhos"

"Eles comentavam que as crianças estavam experimentando mais os alimentos"

“Os pais comentaram que eles estão comendo mais frutas depois do trabalho realizado no Colégio"

"Os pais comentavam que as crianças falavam que era necessário comer coisas saudáveis"

"Comentaram da importância dada em relação à mudança de alimentação"

“Alguns pais mostraram-se surpresos em saber que seus filhos haviam experimentado e gostado de hortaliça ou 
legumes que não queriam experimentar em casa e na escola o fizeram, passando depois a comer em casa"

"Os pais estão mais preocupados em não mandar 'porcarias'"

A maior preocupação por parte das crianças era a composição do lanchinho levado para a escola. Alguns relataram a preocupação em não levar mais salgadinhos fritos.

“As crianças até hoje falam bastante sobre alimentação saudável, importância das frutas, queijos, leite, peixe, etc."

"Alguns alunos vinham após o almoço contando que haviam comido salada ou verdura. No lanche, também gostaram de mostrar aos amigos que haviam trazido frutas"

"Data de validade, valor calórico agora são assuntos abordados freqüentemente por eles"

"Comentam sobre alimentos saudáveis e vigiam o lanchinho" 
"Frases do tipo: - Não posso comer muito salgadinho!"

"Das próprias crianças: cuidado com os salgadinhos"

"Tia, precisa comer bastante verdura e fruta para crescer

e ficar forte"

"Tia, agora eu só trago lanche que faz bem para a minha saúde"

"Tem que comer para ficar forte"

"A laranja tem vitamina C e faz bem para a saúde"

"Ficaram preocupados com a validade, não abusar de salgadinhos e refrigerante".

É importante ressaltar que dois educadores relataram que as maiores mudanças foram observadas no período próximo à discussão do assunto "alimentação saudável" e que, aos poucos, as crianças retomaram antigos hábitos refletidos nos lanchinhos levados para a escola. 
"No começo foi mais forte, as crianças traziam frutas; depois foi voltando ao normal. Acredito que ficou mais na intenção"

“A princípio, observei mudanças nos lanches trazidos de casa, mas depois de algum tempo, voltou ao que era antes"

A opinião dos pais a respeito do Projeto foi percebida ao responderem a pergunta "Como você observa o retorno de seu (sua) filho (a) em relação ao que vivencia na escola?". Os Coordenadores do curso selecionaram todas as fichas que continham qualquer menção às atividades relacionadas à Educação Nutricional (5\% do total de fichas entregues). Os depoimentos dos pais foram os seguintes:

"Meu filho sempre comenta em casa, o que aprendeu na escola sobre matemática, alimentação, canções sobre bichos, etc."

"A G. sempre está trazendo vivências novas como, por exemplo 'uma alimentação saudável' " 
"O E. gosta de ensinar tudo o que aprende na escola, como ter uma boa alimentação e mostrar todo tipo de alimento que tem vitamina"

“A G. demonstra todos os dias as coisas novas aprendidas na escola, ultimamente, sobre os alimentos"

"... contando muitas novidades, nos ensinando versinhos e músicas, procurando comer tudo o que a 'tia' disse que é bom para a saúde"

"... tem dado importância à saúde, alimentação, higiene sempre trazendo relações com super-heróis"

"Meus filhos têm aprendido sobre tudo: comportamento adequado com os amigos, alimentação correta, além de outras coisas como cantar, contar os números, aprender as cores, enriquecimento do vocabulário. Enfim, tudo!"

“Traz e fala de atitudes que devemos ter, lavar as mãos antes de comer, não brigar com os amigos, comer tudo, escovar os dentes" 
"Sempre ficamos orgulhosos quando ouvimos nossa filha comentar durante o jantar sobre os alimentos que fazem bem à saúde elou falar sobre a importância de se economizar energia. Esses são alguns exemplos de como nossa filha é estimulada a pensar e refletir sobre assuntos rotineiros"

\subsection{4 - Avaliação da continuidade do programa}

Foi possível verificar que a discussão sobre alimentação saudável faz parte do currículo escolar. A coordenação desenvolve, a cada ano, um plano geral de estudos que determinam competências e habilidades para o curso de educação infantil. Os cuidados com alimentação são abordados nas seguintes áreas de enfoque: "formação pessoal e social" e "natureza e sociedade".

Com base nesse plano, cada professor titular é responsável por elaborar atividades práticas a serem desenvolvidas juntamente com os alunos no decorrer do ano letivo, a fim de cumprir os objetivos propostos pela coordenação.

No ano seguinte ao desenvolvimento do Projeto, $15 \%$ (5) dos professores que participaram do treinamento solicitaram ajuda do nutricionista para desenvolver com as crianças, atividades relacionadas à higienização de frutas e hortaliças e preparo de saladas. 
Outros professores continuaram a realizar, esporadicamente, diversos tipos de atividades sugeridas no Projeto, tais como: visitas a supermercados e feiras, aulas de culinária, jogos e leituras complementares.

Além disso, estabeleceu-se um canal aberto de comunicação entre nutricionista, coordenadoras e professores, no qual há sempre a possibilidade de esclarecimentos de dúvidas e oportunidades para novas sugestões. 
6 - DISCUSSÃO 


\section{6- DISCUSSÃO}

Os resultados apresentados anteriormente apontam para reflexões e comentários pertinentes à condução de uma conclusão condizente.

\section{1- Características da população}

O observado na escola - $100 \%$ de mulheres atuando como educadoras infantis - é uma realidade mundial. Um levantamento estatístico realizado pela Unesco revela que em 1990, as professoras eram responsáveis por $95 \%$ da atuação em educação infantil no mundo. Na Europa, elas participavam com $99 \%$ e, na América, com $96 \%$. No Brasil, dados apontavam que $99 \%$ dos educadores de educação infantil eram do sexo feminino (SAPAROLLI 1998).

A bibliografia recente tem se preocupado com o tema do magistério como profissão feminina. Segundo SAPAROLLI (1998), dentre os diversos fatores relacionados à elevada proporção de mulheres responsáveis pela educação infantil, destacam-se os seguintes:

- fatores históricos - a escola normal (magistério) representou por um longo período uma das poucas oportunidades das mulheres continuarem seus estudos além do primário;

- sociais - baixos salários, condições inadequadas de emprego e o baixo status da profissão; 
- políticas de atendimento à criança - há visões que associam homens à violência contra menores, o que gera preocupações e ansiedades quanto à hipótese de abuso contra a criança; - gênero feminino - a função de educador infantil é de gênero feminino por estar ligada à produção da vida: educar e cuidar de crianças pequenas.

ARCE (2001) descreve a trajetória da associação da imagem do profissional de educação infantil como sendo da mulher "naturalmente" habilitada para o cuidado com a criança. Aponta os educadores que mais influenciaram essa modalidade: Rosseau, Froebel e Montessori. Para Rosseau, a mulher é responsável pela criança mais do que apenas o ato de dar à luz, mas também de amamentar e promover a primeira forma de interação entre o recém nascido e outro ser humano. Froebel e Montessori consideram a mãe como educadora nata (toda mulher teria adormecidos dentro de si os dons da maternidade e de educadora da primeira infância), sendo considerada a figura ideal para atuar com crianças menores de 6 anos

Com o objetivo de modificar esse quadro no Brasil, vem ocorrendo, nos últimos anos, uma movimentação por parte de profissionais da educação para a formação educacional e qualificação profissional do educador infantil, no sentido de eliminar as diferenças de gênero, revalorizando uma atividade de produção de vida.

Em relação à média de idade, os professores participantes da pesquisa apresentaram-se acima do encontrado no Estado de São Paulo nas escolas de educação 
infantil da rede particular de ensino. O Censo do Professor realizado em 1997 revela que a média de idade neste segmento da educação é de 30,68 anos (MEC/INEP/SEEC 2002). Analisando a média e desvio padrão encontrados na população estudada - 35, 5 e 11,3 anos respectivamente, pode-se considerar que possivelmente esse número tenha sido influenciado pela distância da idade de um dos professores para com os demais, perceptível pelo elevado desvio padrão.

O grau de escolaridade dos professores estudados apresenta-se de forma bastante diferenciada da realidade atual brasileira. Informações estatísticas relativas à situação dos professores quanto à formação profissional realizadas pelo MEC em 1997, revelaram que $16,1 \%$ dos professores de educação infantil possuíam formação fundamental - não passaram da oitava série do ensino fundamental; $65,7 \%$ com formação de nível médio - magistério ou outro; e apenas $18,2 \%$ com formação superior (SEF/ME 1999). Esses dados revelam uma grande quantidade de professores sem habilitação específica para o exercício profissional na educação infantil, uma situação dramática. Com o objetivo de aperfeiçoar a formação dos profissionais da educação, a Lei $\mathrm{n}^{\circ}$ 9.394, de 20 de dezembro de 1996, denominada Diretrizes e Bases da Educação Nacional, dispõe que até o fim da Década da Educação (2007) “somente serão admitidos professores habilitados em nivel superior ou formados por treinamento em serviço" (BRASIL 1996). A população estudada diferencia-se ainda mais, uma vez que já atende a essa Lei, apresentando, praticamente, uma relação inversamente proporcional à situação atual da formação do professor brasileiro. Além disso, entre os professores com formação superior, ressalta-se que $21 \%$ apresentaram título de pós-graduação. 
A escolaridade diferenciada pode haver colaborado para um elevado valor médio de acertos nas respostas dos questionários antes mesmo do treinamento $(8,57)$. Os resultados da aplicação do mesmo questionário em população de professores com menor graduação, comparados aos dados obtidos na população estudada, poderia revelar a influência que o fator escolaridade exerce sobre o conhecimento técnico.

\section{2- Impacto da interven cão educativa nos conhecimentos sobre nutrição}

O aumento estatisticamente significante da média geral da avaliação obtida após a intervenção educativa permitiu verificar que houve mudança no conhecimento relativo aos temas de nutrição e alimentação.

De acordo com as respostas apresentadas no questionário antes do programa de capacitação, os temas de menor domínio dos professores foram os relacionados aos alimentos energéticos (questão 3) e aos componentes de uma alimentação saudável (questão 5). Exatamente as respostas dessas questões foram as que apresentaram maior variância entre as médias antes e após a intervenção, representando um aumento significativo no conhecimento dos temas relatados

Para a pergunta de número 4 houve redução da média de acertos obtida na segunda fase. Essa redução pode ser justificada pelo longo espaço de tempo entre a primeira e segunda fase, falha no treinamento (não houve apresentação de frutas e hortaliças in natura, que possivelmente auxiliariam na fixação de conceitos sobre 
composição de vitaminas e minerais), informação não suficiente no material didático, ou ainda influência de fatores externos.

Possivelmente, se a aplicação do segundo questionário fosse mais próximo às atividades de intervenção, os valores médios de acertos teriam sido maiores do que sendo realizada após um ano.

CONTENTO e col. (1995) já haviam verificado que todos estudos sobre educação nutricional que avaliaram os conhecimentos adquiridos por professores após treinamento apresentaram aumentos estatisticamente significantes. Ainda verificaram que os valores obtidos no segundo teste poderiam sofrer redução a partir do sexto mês após a intervenção.

CONTENTO, RANDELL e BASCH (2002) reconhecem que o método de avaliação de aumento do conhecimento - pré-teste e pós-teste, aumenta a eficácia da pesquisa, mas apontam que as mudanças podem ser influenciadas por fatores independentes da intervenção.

Em sua exposição sobre o treinamento e sua eficácia, SANTOS (1996) enfoca que o simples fato de um indivíduo participar de um programa de treinamento não lhe assegura a aquisição de novos conhecimentos. $O$ sucesso do treinamento pode depender de fatores externos como o sistema de valores (experiências de vida, concepção do mundo) e aspirações (motivações, o quanto o treinando está interessado no assunto). 
A qualidade do treinamento pode, também, ser reflexo da qualidade do instrutor. $\mathrm{O}$ treinador precisa não somente conhecer $\mathrm{o}$ assunto que está transmitindo como também a arte de treinar (COSTA 1994).

Com a finalidade de conhecer os fatores que podem comprometer a qualidade do treinamento, é importante que as ações educativas possam ser avaliadas. A avaliação objetiva esclarecer controvérsias, dirimir dúvidas sobre falsos pressupostos e possibilitar ações que resultem da compreensão do objeto avaliado. Avaliar pressupõe definir princípios em função de objetivos que se pretendem alcançar. Não possui uma finalidade em si, mas subsidia o curso de uma ação que visa construir um resultado previamente definido (PIZZA 1991; BURIASCO 2000).

Analisando os relatos dos professores que consideraram o material elaborado e abordagem do treinamento de fácil compreensão, pode-se considerar que as respostas do segundo teste sofreram influências de conhecimentos externos.

A capacitação do professor de educação infantil precisa ser intensificada nas diversas áreas de atuação do profissional. Segundo CAMPOS (1997) a educação de crianças pequenas talvez seja uma das áreas educacionais que mais retribuam à sociedade os recursos nela investidos. 


\section{3- Avaliação da estratégia didática da intervenção educativa}

Com referência ao treinamento realizado com os professores, observou-se em seus discursos que foi possível a participação intensiva de cada um. $O$ sistema de treinamento por processo dinâmico e utilização de jogos com adultos tem sido apontado como método que desperta o interesse do aprendiz, tornando-o sujeito ativo no processo de ensino-aprendizagem (ZACCARELLI, COELHO e SILVA 2000). No entanto, através dos discursos referentes às atividades desenvolvidas no dia do treinamento, observou-se que os conteúdos mais fixados foram aqueles que cada grupo especificamente abordou, havendo pouca citação às atividades realizadas por outros grupos. A estratégia do treinamento pode ter provocado este desvio, uma vez que cada grupo estava absorto em sua tarefa de apresentar para todos os outros participantes os resultados verificados para cada situação-problema apresentada.

O envolvimento dos professores no projeto foi possível devido ao incentivo por parte da coordenação da escola que propiciou momentos inseridos no contexto de trabalho para treinamento e avaliação. Os procedimentos, tendo sido realizados no próprio local de trabalho e horário, facilitaram a participação de todos os educadores do curso de educação infantil. Muitos professores, apesar do interesse, não têm tempo ou disposição para aprimorarem seus conhecimentos.

Os freqüentes depoimentos dos professores relatando que utilizaram o "Guia de alimentação para uma vida saudável" como base teórica para o desenvolvimento de atividades para o Projeto evidencia que esse foi um instrumento facilitador para 
ampliação do conhecimento em nutrição. É possivel que, na ausência desse material, a maioria ficasse sem pesquisar informações em literatura técnica apropriada.

LELIS (2001) cita estudo realizado com professores de oitavas séries da rede pública de três Estados da federação brasileira em que, embora $69 \%$ dos professores tenham declarado lerem alguma revista de educação, essa atividade parecia não ser muito intensa: $14 \%$ deles declaram não terem lido nada nos últimos anos; $52 \%$ leram apenas alguns textos ou artigos; $18 \%$ dizem terem lido livros com regularidade. Boa parte dos que afirmaram terem lido algum texto nos últimos três anos não foram capazes de citar qualquer autor ou título e percentual significativo citou apenas um.

\section{4- Repercussōes da capacitação}

Este estudo não teve como objetivo avaliar a mudança de comportamento alimentar dos alunos, porém foi possível verificar que os ensinamentos transmitidos pelos professores refletiram nas escolhas alimentares tanto na escola como em casa. CONTENTO e col. (1995) verificaram que o efeito na avaliação do conhecimento em programas de educação nutricional é sempre positivo, mas nem sempre há mudança significativa no comportamento. Estudos sobre conhecimento em nutrição sempre visam à mudança de comportamento, ainda que não sejam mensuradas. Entretanto, as mudanças somente ocorrem nos indivíduos que já estão motivados, para os outros, são apenas informações. 
Em pesquisa de intervenção nutricional realizada no município de São Paulo com alunos do ensino fundamental, SOSSAI (1984) não obteve a adesão dos pais no programa. Os pais apresentaram-se de forma tão alienada ao estudo que chegaram a relatar que não aderiram ao programa porque tinham coisas mais importantes a fazer. Possivelmente, há 20 anos atrás, o enfoque publicitário sobre alimentação saudável não estivesse tanto em discussão, daí a falta de interesse.

CONTENTO e col. (1995) concluíram que os fatores que contribuem para o sucesso de um programa de educação nutricional cuja população alvo sejam crianças em idade pré-escolar estão relacionados ao envolvimento dos pais e familiares, à metodologia adequada com material apropriado e atividades práticas e à utilização de estratégias de encorajamento.

A assimilação dos conteúdos por parte das crianças, observada a partir dos discursos referentes a mudanças no comportamento alimentar, permitiu avaliar que os professores souberam traduzir o conteúdo teórico para o entendimento da criança. Segundo BOOG (1997), o Nutricionista é o profissional habilitado para promover a educação nutricional, o que não quer dizer que ele deve, por ele mesmo, ensinar diretamente a todos os grupos populacionais. Quando a educação nutricional é promovida pelo nutricionista por meio do contato direto com as crianças, tem-se como vantagem a garantia na precisão das informações e a homogeneidade na metodologia. Porém, é o professor de educação infantil quem possui a prática docente, o conhecimento dos alunos e é capaz de compreender a maneira do aprender da criança. 
Para SOSSAI (1984), o ideal é que o técnico promova treinamento específico para o professor e mantenha supervisão sistemática.

Os professores se envolveram de maneira surpreendente, demonstrando total interesse no desenvolvimento das atividades relacionadas à alimentação saudável. Buscaram informações para complementar o ensino e adquiriram materiais didáticos como livros e brinquedos além de promoverem atividades como visitas a feiras livres e supermercados, aulas de culinária, jogos em computador, músicas e visita a cozinhas industriais.

Para PENTEADO, SEABRA e PEREIRA (1996) a atividade de brincar constitui-se um recurso educativo para a saúde sendo importante que as abordagens possam contar com o apoio de atividades concretas como ilustrações e representações temáticas, no sentido de facilitar a transmissão de conceitos. Sugerem ainda, que o profissional da saúde incentive a construção de brinquedos e brincadeiras para que toda a família do educando possa participar.

CÂMARA e MORAIS (1998) verificaram a influência das práticas pedagógicas no desenvolvimento científico de 40 crianças de diferentes classes sociais matriculadas no jardim de infância e sugerem que a metodologia adotada pela escola/educador exerce o papel de maior importância no padrão de aproveitamento. 0 educador que não tem cuidado com a prática pedagógica pode comprometer o desenvolvimento integral das crianças trazendo conseqüências drásticas. 
Objetivando conhecer a maneira como as crianças interpretam as mensagens relacionadas à nutrição, LYTLE e col (1997) realizaram estudo com 141 alunos entre 2 e 6 anos de idade e verificaram que as crianças pequenas têm dificuldade em interpretar termos mais abstratos como, por exemplo, nutrientes. É fundamental que o educador tenha a habilidade para "traduzir" termos técnicos em linguagem concreta, assimilada pelas crianças.

Os resultados positivos em um processo de educação nutricional para crianças em idade pré-escolar também podem ser influenciados pelo tipo de apelo para uma alimentação saudável. LAWATSCH (1990) investigou o efeito de duas estratégias de ensino em nutrição para 103 crianças no Norte de New Jersey: foco para os benefícios da alimentação saudável (corpo saudável, pele bonita, vivacidade) e para os riscos de uma alimentação desequilibrada (doença, desânimo, corpo feio). Para os dois enfoques foram encontrados aumento estatisticamente significante no conhecimento relacionado à nutrição, porém com maior significância para o apelo positivo.

Por essas razões expostas, não é suficiente que o professor adquira o conhecimento técnico. É necessário que se estabeleça uma relação de diálogo entre o saber popular e o saber técnico, uma parceria entre professores, pais, funcionários da escola e nutricionista (COSTA, RIBEIRO e RIBEIRO 2001).

Um dos professores relatou que utilizou em outra escola os conhecimentos adquiridos no processo de intervenção, com isso, outras crianças foram beneficiadas. 
Verificou-se então, que ao se treinar o professor, a sua abrangência pode ser maior do que a mensurável.

Ao avaliar um curso de educação nutricional para professores, NEAFSEY, JENSEN e BURKLUND (1985) verificaram que 115 professores alcançaram 7057 alunos e alguns relataram que compartilharam o treinamento e materiais obtidos com outros profissionais que não haviam participado do curso, ampliando o alcance de crianças.

Discursos como "os pais pedem sempre orientação quanto ao lanchinho das crianças" ou "os pais estão mais preocupados em não mandar 'porcarias" revelam a preocupação e insegurança que os pais apresentam em relação à composição do lanche escolar. Os pais recorrem à própria escola para orientá-los em relação à alimentação, acreditam que a escola possui o conhecimento. No entanto, parece contraditório quando a própria cantina da escola não oferece opções de lanches mais nutritivos e naturais.

Observando o discurso de duas professoras, foi possível identificar que as maiores mudanças aconteceram em períodos próximos às atividades desenvolvidas. Com o passar do tempo, alguns alunos e pais retomaram antigos hábitos alimentares inadequados. O sistema de educação deve ser contínuo até que o hábito seja consolidado. Para NOGUEIRA (1999), assimilação de conhecimento não é garantia para mudança de comportamento. Ações educativas isoladas tendem a serem esquecidas e seus efeitos desaparecem progressivamente, por isso a sugestão é formalizar os programas de educação até que seja refletido em mudanças de hábitos. $\mathrm{O}$ reforço 
contínuo por meio da vivência cotidiana em um ambiente formal de ensino acaba por provocar melhorias que refletem em toda a família.

O Ministério da Educação e do Desporto (MEC) estabeleceu um referencial curricular nacional, no qual propõe que as escolas de educação infantil abordem, no decorrer do ano letivo, temas relacionados aos cuidados com a alimentação e saúde (MEC 1998). A adoção dessas medidas pela escola estudada, constituiu um importante fator para a viabilização do desenvolvimento e continuidade do programa de educação nutricional

A continuidade intensificada do programa de educação nutricional, possivelmente tenha sido dificultada pelo excesso de atribuições e responsabilidades que a escola recebe atualmente. Para MICOTTI (1994), BARRETO (1997) e CAVALIERE (2002), a escola de educação infantil no Brasil tem enfrentado diversos desafios, entre eles a necessidade de inclusão no currículo escolar de modalidades do conhecimento que não estão inseridas em disciplinas específicas. A tendência é de atribuir à escola responsabilidades e compromissos educacionais bem mais amplos do que, tradicionalmente, sempre se fez.

Educação nutricional como processo contínuo, integrada ao currículo escolar, desde a mais tenra idade, abrangendo as mais diversas áreas de conhecimentos específicos como Matemática, Linguagem, Ciências, Geografia, História, Educação Física tem sido a sugestão de diversos autores (CONTENTO 1995; MARTINEZ 1996; 
HARRIS e col. 1997; RAMOS e STEIN 2000; SOUZA e ALVES 2000; COSTA, RIBEIRO e RIBEIRO 2001; PÉREZ-RODRIGO e ARANCETA 2001).

Como proposta diante da necessidade de conciliar as diversas áreas do setor da saúde com as mudanças no ambiente e currículo escolar recomendadas pelo Ministério da Educação e do Desporto, surge o projeto de Escola Promotora de Saúde. ROCHA, MARCELO e PEREIRA (2002) apresentam com muita clareza a importância e funcionalidade da proposta do ensino interdisciplinar com atividades integradas. A Escola Promotora de Saúde adota uma construção interdisciplinar e intersetorial na qual há integração de disciplinas e consenso entre as diversas áreas de saúde, de modo que os interesses predominantes são os de uma realidade mais saudável.

A construção de um ambiente mais saudável e favorável à manutenção da vida será possível a partir da renúncia dos próprios interesses a favor da integração para o bem comum. 


\section{7-CONCLUSÕES}

Os resultados obtidos nesta pesquisa permitem concluir que:

$\checkmark \quad$ Ainda que a população estudada tenha se diferenciado quanto ao grau de escolaridade, alguns professores apresentaram falhas conceituais em temas de alimentação e nutrição. A intervenção educativa constituiu um recurso importante e significativo para promover o aumento de informações.

$\checkmark \quad$ Os materiais didáticos de apoio foram instrumentos facilitadores para a promoção da educação nutricional e viabilizaram a difusão do conhecimento para outros setores e escolas. 
Recomendações

68

8- RECOMENDAÇÕES 


\section{8- RECOMENDACÕES}

Com base nos achados nessa pesquisa, recomenda-se que:

$\checkmark \quad$ A coordenação da escola incentive a promoção de atividades voltadas para a educação em nutrição, viabilizando o envolvimento de todos os profissionais da escola, alunos e familiares; atuando também, de forma direta, sobre o fornecimento de lanches por parte da cantina escolar.

$\checkmark \quad$ Novas pesquisas de investigação sejam realizadas de modo a possibilitar a avaliação na mudança do comportamento alimentar.

$\checkmark \quad$ Os professores sejam periodicamente capacitados, participando de cursos de atualização e reciclagem orientados por nutricionista.

$\checkmark \quad$ Educação nutricional aconteça como parte de um processo contínuo intenso, integrada às diversas disciplinas para que possa promover mudança no comportamento alimentar. 
9. REFERÊNCIAS 


\section{REFERÊNCIAS}

[ADA] AMERICAN DIETETIC ASSOCIATION. Position of the American Dietetic Association: Nutrition standards for child-care programs. $J$ Am Diet Assoc 1999;99:981-8.

Almeida SS, Nascimento PCBD, Quaioti TCB. Quantidade e qualidade de produtos alimentícios anunciados na televisão brasileira. Rev Saúde Pública 2002;36(3):353-5.

Antunes C. Jogos para a estimulação das múltiplas inteligências. $6^{\mathrm{a}}$ ed. Petrópolis, $\mathrm{RJ} ; 2000$.

Aquino RC. Alimentos industrializados na dieta das crianças do município de São Paulo. São Paulo; 1999. [Dissertação de Mestrado -FCF/FEA/FSP - USP]

Arce A. Documentação oficial e o mito da educadora nata na educação infantil. Caderno de Pesquisa: Fundação Carlos Chagas 2001; (113):167-84.

Auld GW, Romaniello C, Heimendinger J, Hambidge C, Hambidge M. Outcomes from a school-based nutrition education program alternating special resource teachers and classroom teachers. J School Health 1999; 69(10): 403-8.

Barreto AMRF. Educação infantil no Brasil: desafios colocados. Cadernos CEDES $1997 ; 37: 7-21$

Barreto ML, Carmo EH. Tendências recentes das doenças crônicas no Brasil. In: Lessa I. $O$ adulto brasileiro $e$ as doenças da modernidade - epidemiologia das doenças crônicas não-transmissíveis. São Paulo: Hucitec; 1998. p.15-27.

Birch LL. The relationship between children's food preferences and those of their parents. J Nutr Educ 1980;12:14-18. 
Birch LL, Fisher JO. Development of eating behaviour among children and adolescents. Pediatrics 1998;101:539-549.

Bissoli MC, Lanzillotti HS. Educação nutricional como forma de intervenção: avaliação de uma proposta para pré-escolares. Rev Nutr PUCCAMP 1997; 10(2):10713.

Bógus CM, Pereira IMT, Westphal MF. Educação em saúde na escola: como está a formação de professores de $1^{\mathrm{a}}$ à $4^{\mathrm{a}}$ série do $1^{\circ}$ grau? Rev Bras Saúde Esc $1990 ; 1(1) 14-17$.

Boog MCF. Educação nutricional em serviços públicos de saúde: busca de espaço para ação efetiva. São Paulo; 1996. [Tese de Doutorado - Faculdade de Saúde Pública da USP].

Boog MCF. Educação nutricional: passado, presente e futuro. Rev Nutr PUCCAMP 1997; 10 (1): 5 - 19.

Borzekowski DLG, Robinson TN. The 30-second effect: na experiment revealing the impact of television commercials on food preferences of preschoolers. $J$ Am Diet Assoc 2001;101:42-6

Brasil. Ministério da Educação e do Desporto. Lei 5692 de 11 de agosto de 1971: fixa diretrizes e bases para o ensino de primeiro e segundo graus e dá outras providências. Documento129. 1971;400-16

Brasil. Ministério da Educação e do Desporto. Lei 9394 de 20 de dezembro de 1996: Lei de diretrizes e bases da educação nacional. São Paulo: Ed Brasil, 1996 a, 1-34

Buriasco RLC. Algumas considerações sobre avaliação educacional. Est Aval Educ FCC 2002; 22:155-78. 
Caldeira GV. Consumo habitual de alimentos de escolares da rede municipal de ensino de Florianópolis-SC. São Paulo; 1998.[Dissertação de Mestrado - Faculdade de Saúde Pública da USP].

Câmara MJ, Morais AM. O desenvolvimento científico no jardim de infância: influência das práticas pedagógicas. Rev Educ-FC da UL 1998;7(2):179-99.

Campos MM. Educação infantil: o debate e a pesquisa. Caderno de Pesquisa: Fundação Carlos Chagas 1997; julho (101):113-27.

Cason K. Evaluation of a preschool nutrition education program based on the theory of multiple intelligences. $J$ Nutr Educ 2001;33:161-64.

Castro MPS. Hábitos alimentares de estudantes brasileiros das zonas urbana e rural: um estudo de Garça - São Paulo. São Paulo; 2001.[Dissertação de Mestrado FCF/FEA/FSP - USP].

Cavaliere AMV. Educação integral: uma nova identidade para a escola brasileira? Educ Soc 2002; 23(81):247-70

Cervato AM, Mazzilli RN, Martins IS, Marucci MF. Dieta habitual e fatores de risco para doenças cardiovasculares. Rev Saúde Pública 1997;31(3):227-35.

Contento IR, Balch GI, Bronner YL, Paige DM et al. The effectiveness of nutrition education and implications for nutrition policy, programs and research: a review of research. J Nutr Educ 1995;27(6)

Contento IR, Randell JS, Basch CE. Review and analysis measures used in nutrition education intervention research. $J$ Nutr Educ 2002; 34:2-25

Cornacchia HJ, Olsen LK, Nickerson CJ. Methods and techniques in health teaching. In: Health in elementary schools. USA, 1988. p.296-305. 
Costa AA. Novas tendências do treinamento. $\operatorname{Rev} A d m$ Publ 1994; 4:1 18-29

Costa EQ, Ribeiro VMB, Ribeiro ECO. Programa de alimentação escolar: espaço de aprendizagem e produção de conhecimento. Rev Nutr PUCCAMP 2001;14(3):22529.

Coutinho W. Obesidade: conceitos e classificação. In: Nunes MAN. Transtornos alimentares e obesidade. São Paulo: Artmed, 1998. p.197-215.

Dawson-Saunders B, Trapp RG. A lange medical book: basic \& clinic bioestatistics. $2^{\text {nd }}$ ed. Norwalk: Appleton \& Lange; 1994.

Dietz WH. Health consequences of obesity in youth: childhood predictos os adult disease. Pediatrics 1998;101:518-25.

Doyle EI, Feldman RHL. Factors affecting nutrition behavior among middle-class adolescents in urban area of Northem region of Brazil. Rev Saúde Pública 1997;31(4):342-50.

Drumond MJ, Barros MBA. Desigualdades socioespaciais na mortalidade do adulto no municipio de São Paulo. Rev Bras Epidemiol 1999;2(1/2):34-49.

Fisberg M, Vítolo MR. Educação nutricional e recomendações nutricionais do préescolar e do escolar. In: Conceição JAN. Saúde escolar - a criança, a vida e a escola. São Paulo: Sarvier, 1994. p.55-61.

Focesi E. Educação em saúde: campos de atuação na área escolar. Rev Bras Saúde Escolar 1990; 1 (1):19-21. 
Gaglione CP. Estudo do conteúdo relacionado à mutrição em livros didáticos de ciências utilizados no ensino brasileiro. São Paulo; 1999. [Dissertação de Mestrado Escola Paulista de Medicina - UNIFESP].

Harris KJ e col. Reducing elementary school children's risks for chronic diseases through school lunch modifications, nutrition education, and physical activity interventions. J Nutr Educ 1997;29:196-202.

Holcomb JD, Lira J, Kingery PM, Smith DW, Lane D, Goodway J. Evaluation of jump into action: a program to reduce the risk of non-insulin dependent diabetes mellitus in school children on the Texas-Mexico border. J School Health 1998; 68 (7): 282-8.

Holland CV. A creche e seu papel na formação de práticas alimentares. São Paulo; 1999. [Dissertação de Mestrado - Faculdade de Saúde Pública da USP].

Kishimoto TM. Brinquedos e materiais pedagógicos nas escolas infantis. Rev Educ Pesq-FE/USP 2001; 27(2):229-45

Kuhlmann MJ. Histórias da educação infantil brasileira. Rev Bras Educ 2000; 14:518

Lawatsch DE. A comparison of two teaching strategies on nutrition knowledge, attitudes and food behavior of preschool children. J Nutr Educ 1990;22:117-23.

Lelis I. Profissão docente: uma rede de histórias. Rev Bras Educ 2001; 17:40-9

Lessa I. Doenças crônicas não-transmissíveis. In: Lessa I. $O$ adulto brasileiro e as doenças da modernidade - epidemiologia das doenças crônicas não-transmissíveis. São Paulo: Hucitec; 1998. p.29-42. 
Levine J. Food industry marketing in elementary schools: implications for school health professionals. J School Health 1999; 69(7): 290-2.

Levine J, Gussow JD. Nutrition professionals' knowlegde of and attitudes toward the food industry's education and marketing programs in elementary schools. J Am Diet Assoc 1999;99:973-976.

Lima ES. Gênese e constituição da educação alimentar: a instauração da norma. São Paulo; 1997. [Tese de Doutorado - Pontifícia Universidade Católica].

Lopes MG. Jogos na educação - criar, fazer, jogar. $4^{\text {a }}$ ed. São Paulo: Cortez; 2001.

Lytle LA, Eldridge AL, Kotz K, Piper J, Williams S, Kalina B. Children's interpretation of nutrition messages. $J$ Nutr Educ 1997;29:128-36.

Martínez AM. La escuela: un espacio de promocion de salud. Psic Esc Educ 1996; 1(1):19-24.

MEC Referencial curricular nacional para a educação infantil. Brasília 1998.

MEC/INEP/SEEC. Censo do Professor 1997. Disponivel em internet <URL:http://www.inep.gov.br > [02/12/2002].

Micotti MCO. A elaboração do plano de ensino na educação pré-escolar. Educação: Teoria e Prática 1994; 2:30-6.

Mondini L, Monteiro CA. Mudanças no padrão de alimentação. In: Monteiro CA. Velhos e novos males da sanide no Brasil: evolução do país e de suas doenças. São Paulo: Hucitec; 1995. p.79-89. 
Monteiro CA, lunes RF, Torres AM. A evolução do país e de suas doenças: síntese, hipóteses e implicações. In: Monteiro CA. Velhos e novos males da saúde no Brasil: evolução do país e de suas doenças. São Paulo: Hucitec; 1995. p.349-56.

Monteiro CA, Mondini L, Costa RBL. Mudanças na composição e adequação nutricional da dieta familiar nas áreas metropolitanas do Brasil (1988-1996). Rev Saúde Pública 2000; 34(3):251-8.

Monteiro CA, Mondini L, Souza ALM, Popkin BM. Da desnutrição para a obesidade: a transição nutricional no Brasil. In: Monteiro CA. Velhos e novos males da saúde no Brasil: evolução do país e de suas doenças. São Paulo: Hucitec; 1995. p.247-255.

Motta DG, Boog MCF. Fundamentos do comportamento alimentar. In: Motta DG e Boog MCF. Educação Nutricional. São Paulo: Ibrasa; 1987; p.34-54.

Neafsey PJ, Jensen HC, Burklund SS. Evaluation of a nutrition education course for teachers. J Nutr Educ 1985;17(4):126-29

Nogueira LC. Avaliação do custo-eficácia de uma ação educativa em mutrição e higiene. São Paulo; 1999. [Dissertação de Mestrado - FEA/FCF/FSP - USP].

Penteado RZ, Seabra MN, Pereira IMTB. Ações educativas em saúde da criança: o brincar enquanto recurso para participação da família. Rev Bras Cresc Desenv Hum $1996 ; 6(1 / 2): 49-56$.

Pérez-Rodrigo C, Aranceta J. School-based nutrition education: lessons learned and new perspectives. Public Health Nutr 2001; 4(1 A):131-9

Pizza WJ. O que todo mundo sabe de treinamento. Rev Adm Púb 2001; 25(2)93:102. 
Ramos M, Stein LM. Desenvolvimento do comportamento alimentar infantil. $J$ Pediatr 2000;76(supl.3):S229-S237.

Rego RA e col. Fatores de risco para doenças crônicas não-transmissíveis: inquérito domiciliar no município de São Paulo, SP (Brasil). Metodologia e resultados preliminares. Rev Saúde Pública 1990;24(4):277-285.

Rocha DG, Marcelo VC, Pereira IMTB. Escola promotora da saúde: uma construção interdisciplinar e intersetorial. Rev Bras Cresc Desenv Hum 2002;12(1):57-63.

Roncada MJ. A missão do professor de primeiro grau na prevenção da hipovitaminose A. Rev Bras Saúde Escolar 1992; 2(3/4): $102-7$.

Santos AS. Treinamento e desenvolvimento em ações educativas: uma investigação com profissionais de saúde coletiva. São Paulo; 1996. [Dissertação de Mestrado Faculdades Integradas São Camilo].

Saparolli ECL. A educação infantil e gênero: a participação dos homens como educadores infantis. Rev Pisc da Educ 1998; 6(1): 107-25.

SEF/ME - Secretaria de Educação Fundamental/Ministério da Educação. Referenciais para a formação de professores. Brasília 1999.

Sossai JÁ. Influência da escola sobre alunos e pais na mudança de comportamento relacionado à saúde. São Paulo; 1984. [Tese de Doutorado - Faculdade de Saúde Pública da USP]

Souza CTR, Alves JM. A formação de conceitos científicos por pré-escolares. Rev Bras Cresc Desenv Hum 2000;10(1):91-101.

Stedronsky FM. Child nutrition and health campaign: a member update. $J$ Am Diet Assoc 1998;98:758-759. 
Tomita NE, Nadanovsky P, Vieira AL, Lopes ES. Preferências por alimentos doces e cárie dentária em pré-escolares . Rev Saúde Pública 1999; 33(6):542-46.

Troiano RP, Flegal KM. Overweight children and adolescents: description, epidemiology, and demographics. Pediatrics 1998;101:497-504

Ubeda EML. A educação para a saúde na escola: um estudo de algumas práticas de saúde desenvolvidas na pré-escola. Ribeirão Preto; 1986. [Dissertação de Mestrado Escola de Enfermagem da USP].

Zaccarelli EM, Coelho HDS, Silva MEP. O jogo, como prática educativa, no treinamento para controle higiênico-sanitário, em unidades de alimentação e nutrição. Hig Alim 2000;14(70):23-6 
ANEXO 1 


\section{TERMO DE CONSENTIMENTO LIVRE E ESCLARECIDO}

(de acordo com a resolução 196 de 10/10/1996 do Conselho Nacional de Saúde)

Título da pesquisa: "Capacitação para educação nutricional dirigida a professores de um curso de educação infantil"

Eu aceito participar

voluntariamente do estudo mencionado acima e que está sendo realizado pela pesquisadora Irene Coutinho de Macedo, mestranda da Faculdade de Saúde Pública da Universidade de São Paulo, sob orientação da Prof Dra. Ana Maria Cervato Mancuso, da mesma Instituição.

Fui esclarecido dos seguintes pontos:

- Benefícios: poderei receber informações importantes sobre a alimentação equilibrada para crianças; minha participação no estudo poderá beneficiar a ciência através da publicação dos resultados.

- Riscos: minha participação não representa risco para minha integridade fisica, moral ou mental.

- Método: participarei de um treinamento em grupo, realizado na própria instituição que trabalho, em horário normal de expediente. Submeto-me a uma avaliação anterior e outra posterior ao treinamento.

- Sigilo: terei meu nome mantido em anonimato e os dados individuais que fornecerei serão confidenciais, sendo que somente os resultados coletivos serão divulgados nos meios cientificos.

- Desistência e acesso: fui informado e compreendo que posso, a qualquer tempo no decorrer do estudo, solicitar à pesquisadora informações sobre o mesmo, ter acesso ao material individual transcrito ou desistir da pesquisa sem sofrer qualquer tipo de constrangimento.

De acordo,

Assinatura do Participante

contato: Irene Coutinho de Macedo - tel (11) 38746342 SP email: irene@cbb.g12.br 
ANEXO 2 
Solicitamos o preenchimento desta ficha para conhecermos algumas características do profissional participante da pesquisa “Capacitação para educação nutricional dirigida a professores de um curso de educação infantil"

\section{Perfil do Educador}

Sexo-( ) feminino ( ) masculino

Idade:

Formação acadêmica:

( ) curso magistério em nível II grau

( ) cursando $3^{\circ}$ grau. Curso:

( ) $3^{\circ}$ grau completo. Curso:

( ) cursos de pós graduação, mestrado ou doutorado. Área:

Cargo: ( ) professor

( ) auxiliar de ensino

( ) professor de aulas especiais

Classe trabalhada: ( ) maternal

( ) infantil I

( ) infantil II

( ) infantil III

Mais uma vez agradecemos a sua colaboração para esta pesquisa 
ANEXO 3 
Nome:

Atividade:

Série:

Para as questões abaixo, escolha a alternativa correta

1- O que são nutrientes?

a) alimentos.

b) elementos encontrados nas frutas e verduras.

c) elementos que compõem os alimentos.

d) vitaminas encontradas nas frutas.

e) nenhuma das anteriores.

2- São nutrientes fundamentais para o bom desenvolvimento dos indivíduos:

a) proteínas vegetais e vitaminas.

b) gorduras e minerais.

c) carboidratos e água.

d) proteinas animais e fibras.

e) o conjunto de todas as alternativas.

3- Qual das alternativas contém somente alimentos considerados energéticos?

a) arroz, macarrão, pão, margarina.

b) macarrão, mingau, laranja, couve.

c) sorvete, maçã, feijão, frango.

d) laranja, banana, abacate, alface.

e) bife de figado, queijo, leite, peixe.

4- Quanto às vitaminas e minerais, podemos dizer:

a) estão presentes somente nas carnes e leite e são responsáveis por manter o equilíbrio do organismo.

b) são nutrientes responsáveis por manter o equilíbrio do organismo, auxiliando na digestão e absorção de outros nutrientes. São facilmente encontrados nas frutas e hortaliças.

c) são dificilmente encontrados nos alimentos, devendo ser complementados por complexos vitamínicos.

d) a vitamina mais importante é a $\mathrm{C}$, pois previne de diversas doenças e é facilmente encontrada na laranja e acerola.

e) nenhuma das anteriores.

5- A alimentação saudável pode ser representada por:

a) uma alta ingestão de frutas e hortaliças.

b) uma dieta composta de leite, queijos, iogurtes e ovos.

c) uma dieta composta dos mais variados alimentos, incluindo alimentos fonte de gordura.

d) consumo de alimentos na sua forma mais natural como açúcar mascavo, arroz e pão integral.

e) não comer alimentos gordurosos, chocolates, refrigerantes e salgadinhos. 
6- Quanto às necessidades nutricionais:

a) são iguais para todas as pessoas.

b) Somente as crianças desnutridas têm.

c) As crianças obesas tem em menor proporção.

d) Variam de indivíduo para indivíduo

e) Os adultos não as têm pois já estão completamente formados.

7- Para as crianças, o mais importante é:

a) comer somente frutas e verduras pois são ricas em vitaminas, fundamentais para o bom desenvolvimento das mesmas.

b) não comer alimentos fonte de gordura pois estas se acumulam no organismo, trazendo graves conseqüências ao organismo.

c) comer bastante beterraba pois contém muito ferro e ajuda a prevenir a anemia.

d) comer somente carne branca (frango ou peixe) por conterem menos colesterol do que a carne vermelha.

e) nenhuma das anteriores.

8- As doenças cujas origens não estão diretamente relacionadas ao consumo alimentar são:

a) meningite e hepatite

b) anemia e desnutrição

c) obesidade e cárie dentária

d) hipercolesterolemia e osteoporose

e) diabetes e hipertensão

9- Em relação aos hábitos alimentares, podemos dizer:

a) são formados desde a infância.

b) são fortemente influenciados pela mídia.

c) podem variar entre as comunidades, etnias e religiões.

d) podem mudar de acordo com as necessidades.

e) todas as alternativas estão corretas.

10-Para formação de hábitos alimentares saudáveis nos indivíduos, a escola:

a) pouco pode fazer pois as crianças ainda não conseguem assimilar informações técnicas.

b) não deve abordar questões como alimentação pois não é prioridade para formação escolar.

c) deve se empenhar, pois a alimentação saudável é fundamental para o desenvolvimento integral dos indivíduos.

d) é o ambiente adequado para a educação nutricional pois normalmente, representa o primeiro grupo social depois da família.

e) as alternativas c e d estão corretas.

GABARITO:

\begin{tabular}{|l|c|c|c|c|c|c|c|c|c|c|}
\hline Questões & 1 & 2 & 3 & 4 & 5 & 6 & 7 & 8 & 9 & 10 \\
\hline $\begin{array}{l}\text { Alternativa } \\
\text { correta }\end{array}$ & $\mathrm{C}$ & $\mathrm{E}$ & $\mathrm{A}$ & $\mathrm{B}$ & $\mathrm{C}$ & $\mathrm{D}$ & $\mathrm{E}$ & $\mathrm{A}$ & $\mathrm{E}$ & $\mathrm{E}$ \\
\hline
\end{tabular}


Anexo 4

A4

ANEXO 4 
Solicitamos o preenchimento desta ficha para avaliarmos as atividades realizadas para a pesquisa “Capacitação para educação nutricional dirigida a professores de um curso de educação infantil"

Ficha de Avaliação das Atividades relacionadas ao Programa de Capacitação e ao Projeto de Educação Nutricional

1 - O treinamento do dia 24/03/2001 foi dirigido de forma:

( ) clara, objetiva ( ) confusa

2- Houve alguma atividade, conceito ou informação que mais tenha chamado a sua atenção?

3- Quanto ao "Guia de Alimentação para uma vida saudável”, você ainda o possui?

( ) $\operatorname{sim}($ ) não

4- Utilizou o "Guia" como base teórica para desenvolver alguma atividade com as crianças em classe ou para o Projeto de educação nutricional "?

( ) não

( ) sim. Qual atividade?

5- Quanto aos textos e tabelas, o "Guia" foi apresentado de forma:

( ) fácil compreensão

( ) média compreensão

( ) dificil compreensão 
Comentários:

6- O caderno de receitas, presenteado no dia das mães, colaborou para o envolvimento dos pais no Projeto?

( ) $\operatorname{sim}$ ( ) não

Houve comentários por parte dos pais ou das crianças?

7- Foi possível perceber alguma intenção ou mudança de comportamento em relação à alimentação das crianças?

( ) sim ( ) não

Depoimentos dos pais:

Depoimentos das crianças:

Mais uma vez agradecemos a sua colaboração para esta pesquisa contato: Irene Coutinho de Macedo - tel (11) 38746342 SP email: irene@a)bb.g12.br 
ANEXO 5 


\section{Guia de alimentação e nutrição para uma vida saudável}

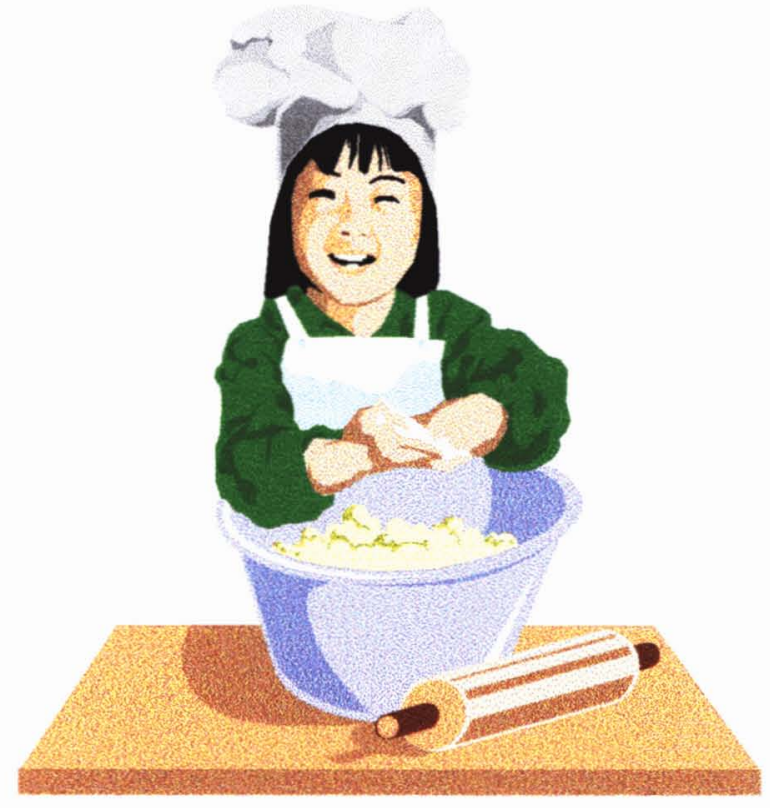

COLÉGIO BATISTA BRASILEIRO

SÃO PAULO

2001 


\section{APRESENTAÇÃO}

Este guia foi elaborado com o objetivo de servir como material de apoio para o desenvolvimento do projeto "Educação nutricional para uma vida saudável" - Educação Infantil do Colégio Batista Brasileiro. nutrição.

Contém informações básicas sobre alimentação e

Esse é um importante instrumento para começarmos a pensar na alimentação saudável como fator fundamental para o crescimento e desenvolvimento adequados das vidas pelas quais também somos responsáveis - as crianças. 


\section{ÍNDICE}

Crescimento e desenvolvimento da criança $\quad 1$

$\begin{array}{ll}\text { Educação nutricional } & 7\end{array}$

$\begin{array}{ll}\text { Alimentos e nutrientes } & 9\end{array}$

$\begin{array}{ll}\text { Alimentação equilibrada } & 16\end{array}$

Importância da higiene na alimentação 20

Alimentação e seus efeitos para a saúde $\quad 21$

Cuidados ao comprar alimentos $\quad 26$

Como comportar-se à mesa $\quad 32$

$\begin{array}{ll}\text { Bibliografia consultada } & 34\end{array}$ 


\section{CRESCIMENTO E DESENVOLVIMENTO DA CRIANCA}

Crescimento e desenvolvimento são termos semelhantes que expressam

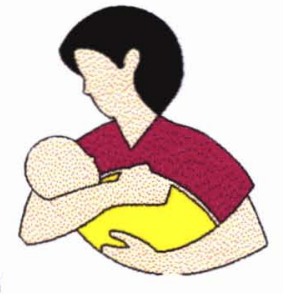
idéias diferentes. Crescimento é o aumento do tamanho da criança tanto no peso como na altura. Desenvolvimento é a capacidade que a criança tem de adquirir habilidades como andar, falar, subir escada, bater palmas e reconhecer cores. Apesar dessa diferença, a alimentação está estreitamente relacionada com os dois termos. Por exemplo, uma criança que apresenta anemia por não se alimentar adequadamente, com certeza terá seu desenvolvimento afetado.

O crescimento da criança depende de vários fatores como a hereditariedade, a gestação, o tipo de alimentação, doenças e 0 uso de medicamentos. Alguns desses fatores não podem ser modificados pela ação humana, mas a alimentação e os cuidados na gestação são áreas de atuação importantes para a obtenção da plena realização do potencial genético da criança. Durante a gestação, a mãe não deve usar medicamentos sem orientação médica, não tomar bebida alcoólica, não fumar e não fazer dietas para perder peso, pois esses fatores influenciam diretamente no crescimento e desenvolvimento do 
bebê. Assim sendo, o crescimento adequado é o resultado de herança genética, gestação controlada, alimentação correta e vida saudável.

A velocidade do crescimento no decorrer da vida não é uniforme. Ora acontece lentamente, ora muito rápido. Em três momentos da vida o crescimento é muito acelerado. $O$ primeiro ocorre na gestação, o segundo durante o primeiro ano de vida $e$ - terceiro na adolescência, quando se começam a definir as características secundárias. sexuais

A avaliação do crescimento

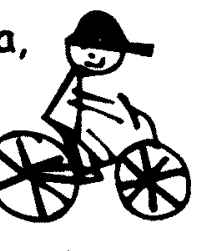

deve ser feita com frequiência e pode ser realizada acompanhando a curva de crescimento (gráfico) de peso e altura em relação à idade. Essa avaliação deve ser feita durante um período de tempo, pois uma única medição da criança não significa muito. É necessário obter várias medidas para se chegar a uma conclusão segura em relação ao seu estado nutricional.

Quando as medidas estiverem fora dos padrões de normalidade, a criança deve ser encaminhada ao pediatra ou nutricionista, pois estes são profissionais habilitados para fazerem uma correta avaliação do estado nutricional. 
Meninos de 1 mês até 36 meses

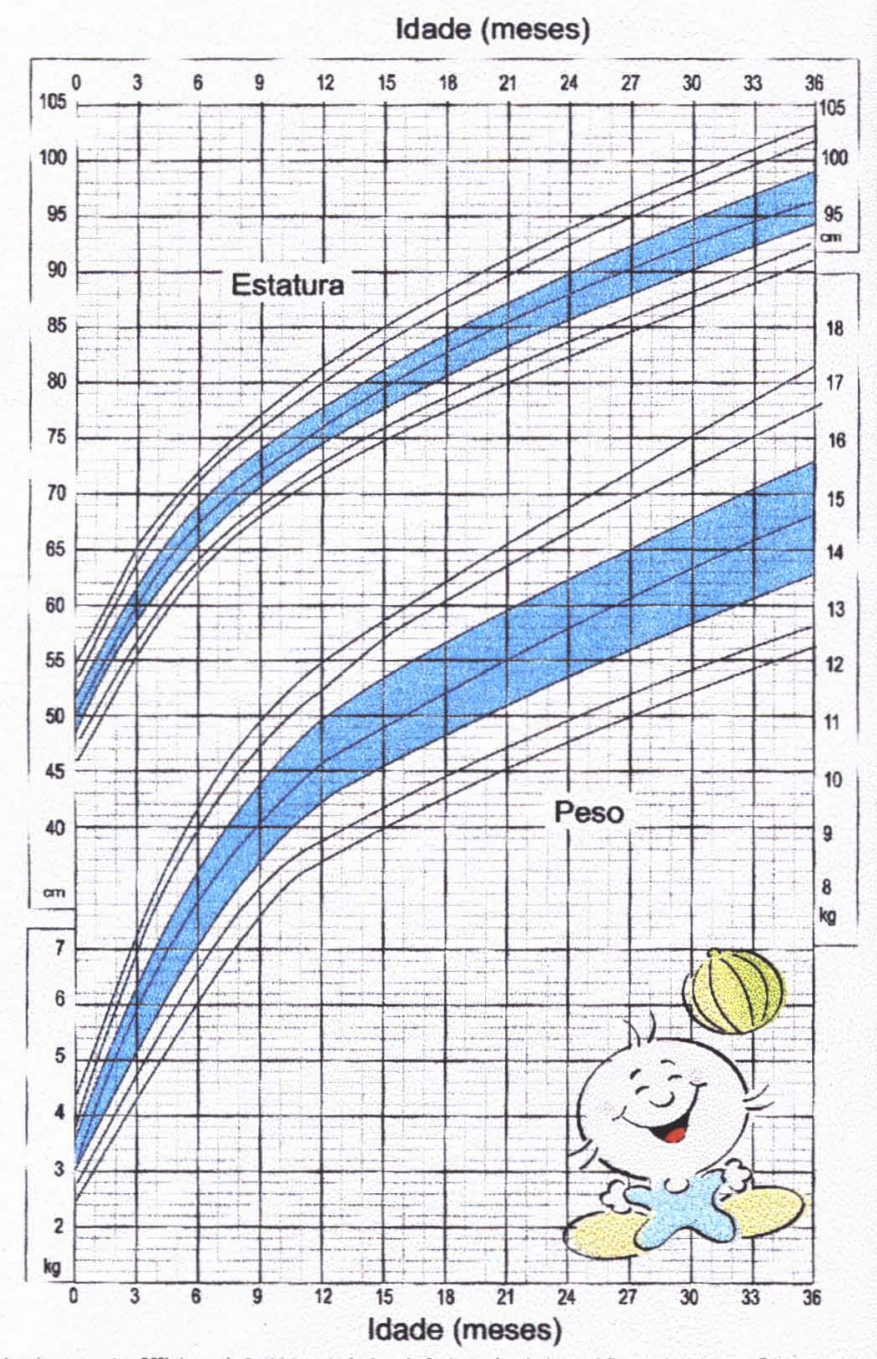


Meninos de 2 anos até 18 anos

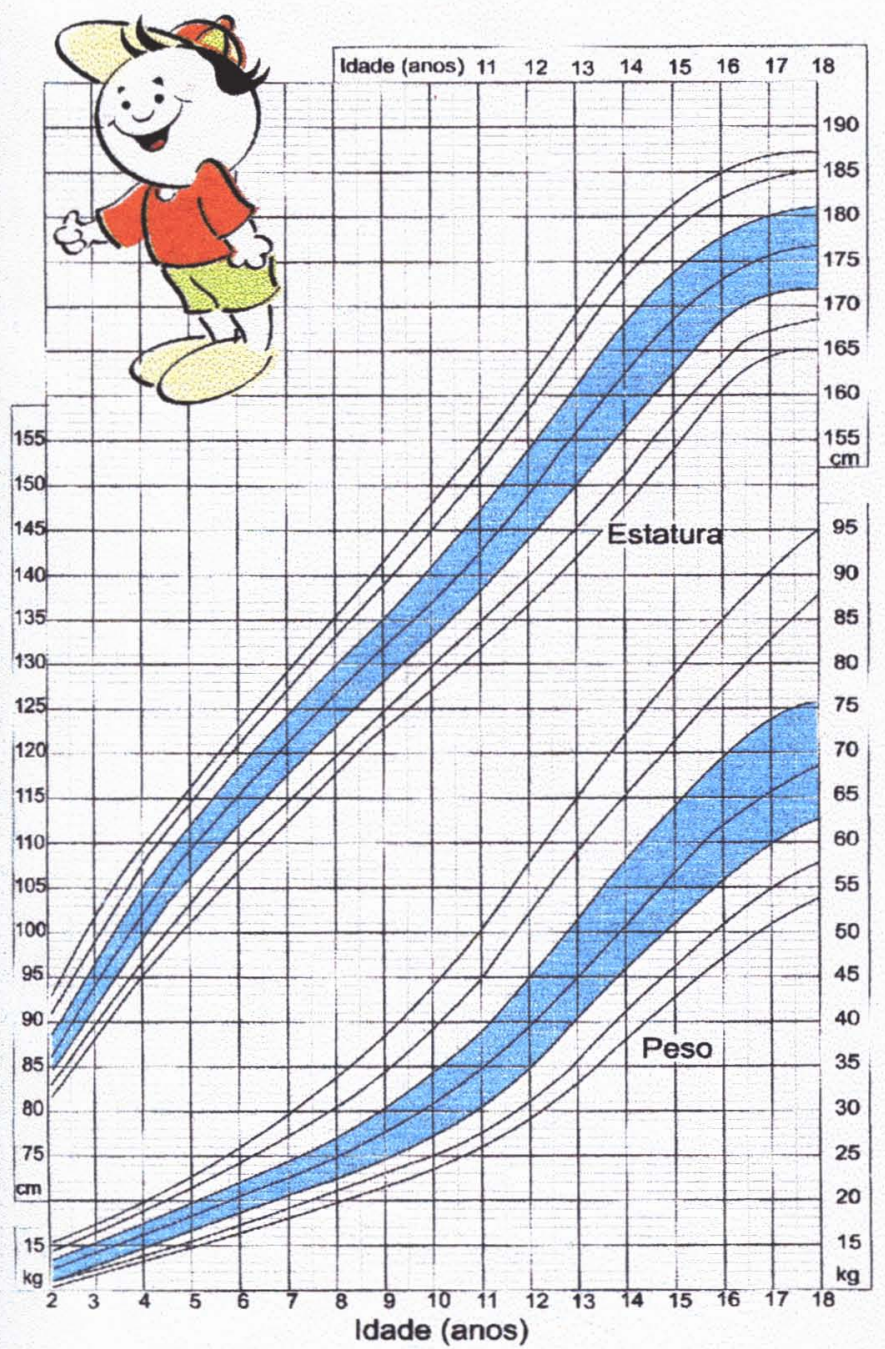


Meninas de 1 mês até 36 meses

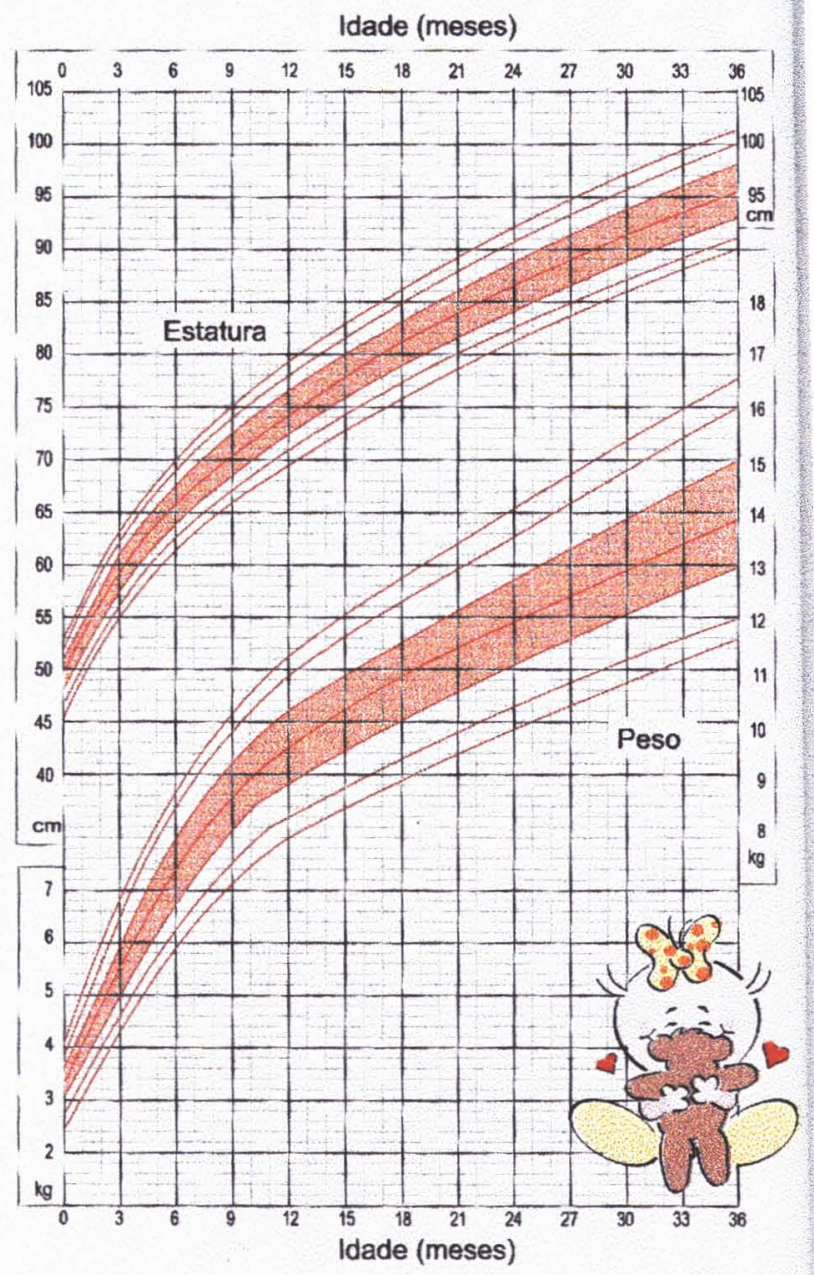


Meninas de 2 anos até 18 anos

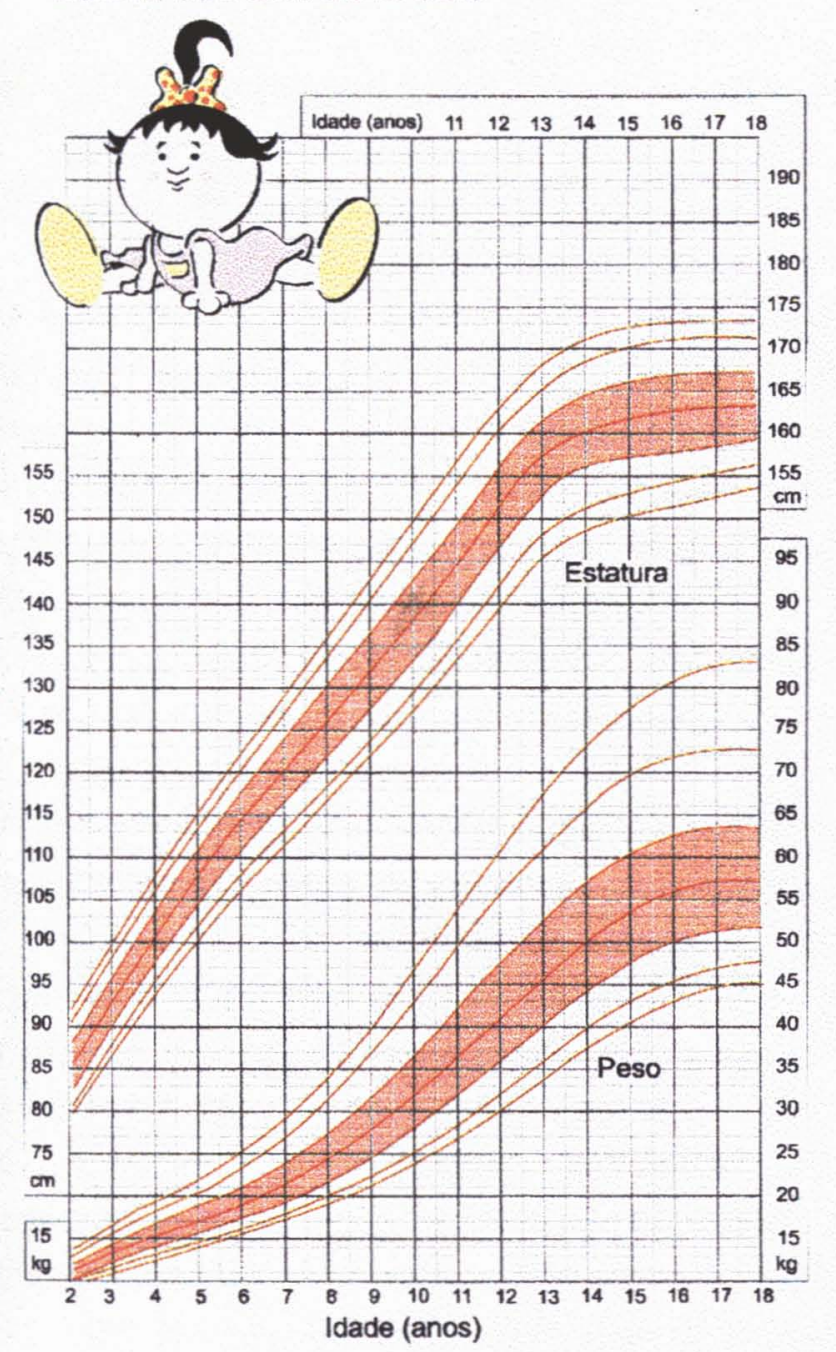




\section{EDUCACÃO NUTRICIONAL}

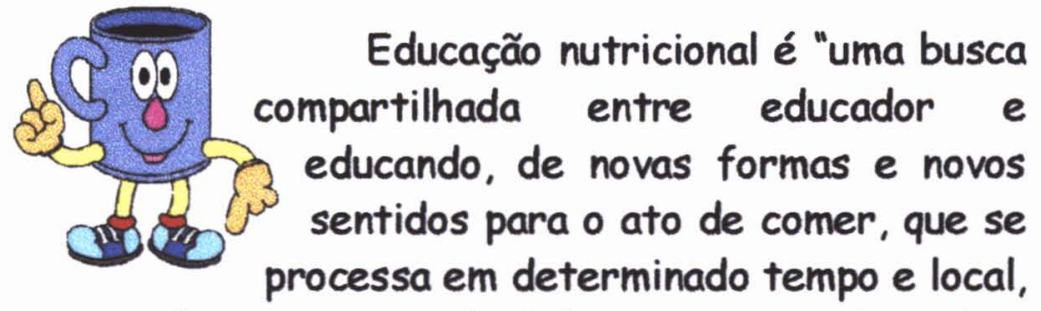
através da interação e do diálogo, por meio da qual se almeja a qualidade e a plenitude do viver". O objetivo principal é criar no educador o desejo de mudar a sua alimentação, levando em consideração os aspectos cognitivos, emocionais e comportamentais. Difundir conhecimentos básicos de alimentação e nutrição, divulgar a importância da nutrição para a manutenção da saúde, ensinar a utilização adequada dos alimentos e incentivar 0 aproveitamento de recursos alimentares regionais são atividades que devem estar inclusas no processo de educação nutricional.

A educação nutricional desde a idade préescolar é a estratégia que tem sido sugerida para conter o avanço da prevalência de doenças crônicodegenerativas, doenças essas diretamente relacionadas ao consumo alimentar inadequado responsáveis por mais de $30 \%$ das causas de morte no Brasil.

Efetivos programas de educação nutricional nas escolas capacitam crianças e adolescentes a fazerem 
escolhas certas sobre comportamentos que promovam a saúde, não somente deles, mas também da família. Da mesma forma, prepara-os para reivindicarem melhor qualidade de vida para a comunidade.

É importante ressaltar que o processo de introdução ou modificação de hábitos alimentares precisa ser efetuado de forma muito cautelosa, muito bem planejado e organizado, pois as ações realizadas podem interferir intensamente na rotina familiar. É necessária uma coesão entre escola, professores, pais e alunos.

O professor, enquanto educador nutricional, deve estar treinado para estabelecer condições criativas e significativas interações com as crianças. É necessário formar educadores voltados para observar as ações das crianças em seus múltiplos aspectos, com maior conhecimento de seus processos de desenvolvimento $e$ da função que a imitação desempenha nesse processo.

Os conhecimentos $e$ informações devem ser passados utilizando-se metodologias diferentes, objetivando a compreensão dos fatos, a descoberta de suas implicações, a análise dos problemas e intercorrências, a busca das razões determinantes a possiveis soluções para a realidade existente. Por isso, a educação nutricional para as crianças de idade escolar mais baixa deve ser introduzida através do 
ensino incidental em todas as oportunidades ou momentos com implicações de saúde durante a rotina diária, reconhecendo a dinâmica do prazer $e$ desprazer na alimentação.

\section{ALIMENTOS E NUTRIENTES}

Alimentos são substâncias
compostas por nutrientes. Os nutrientes introduzidos ao organismo

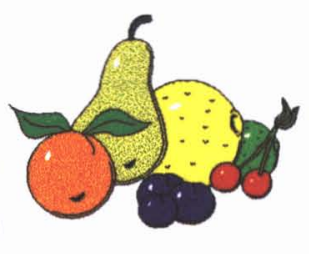
promovem crescimento, reparação dos tecidos, produção de energia e equilíbrio de diversas funções orgânicas; enfim, mantém a vida.

É muito comum confundirmos os termos alimentos e nutrientes. Mas ninguém vai ao açougue $e$ pede um quilo de proteínas (nutriente) e sim carne (alimento). Da mesma forma, o que faz bem para a nossa visão não é a cenoura (alimento) e sim a vitamina $A$ (nutriente). Os alimentos nos fornecem os nutrientes. Não há como adquirirmos nutrientes de forma natural se não for através dos alimentos.

Os nutrientes são: proteínas, carboidratos (glicídios ou açúcares), lipídios (gordura), vitaminas, minerais, fibras e água.

CARBOIDRATOS - são nutrientes que fornecem energia para que o organismo possa manter a 
temperatura (suor ou tremor), exercer as funções vitais (circulação do sangue, respiração, digestão) e realizar trabalhos físicos.

Alimentos ricos em carboidratos:

a) Cereais e derivados: arroz, milho, is farinhas como aveia, trigo, centeio, fubá, massa de macarrão, pizza, pães, biscoitos, torradas e outros.

b) Feculentos e derivados: batata inglesa, batata doce, cará, inhame, mandioca, polvilho, fécula de batata, farinha de mandioca e outros.

c) Açúcares e doces: açúcar refinado, açúcar mascavo, mel, doces em pastas, balas, sorvetes, chocolates, refrigerantes e outros.

PROTEINAS - nutrientes responsáveis pela construção e reparação dos tecidos do corpo (músculos, ossos, sangue, pele, cabelo).

Podem ser de origem animal ou vegetal.

Alimentos ricos em proteínas:

a) De origem animal: carnes (aves, bovino, suíno, peixes), ovos, leite e derivados (queijos, iogurtes, coalhada).

b) De origem vegetal: leguminosas secas como feijões, soja, lentilha, ervilha, grão-de-bico. GORDURAS OU LIPIDIOS - são nutrientes que fornecem energia para o organismo,

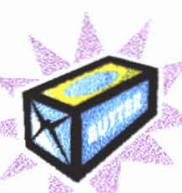


ajudam na regulação térmica e servem como veículos das vitaminas $A, D, E$ e $K$, ou seja, estas vitaminas só são transportadas $e$ absorvidas pelo organismo juntamente com as gorduras da alimentação.

Alimentos fontes de gordura:

a) Origem vegetal: óleos vegetais, azeites, margarinas, frutas oleaginosas (amendoim, castanhas de caju, nozes, amêndoas, polpa de coco), abacate, açaí.

b) Origem animal: manteiga, banha, creme de leite, toucinho, carnes gordas.

c) Preparações: maionese, chantilly, molho rosè, molho tártaro, entre outras.

VITAMINAS E MINERAIS - são nutrientes que regulam as funções do organismo, como facilitar a digestão, proteger a pele, a visão, os dentes, aumentar a resistência do organismo contra infecções e facilitar a utilização de outros nutrientes. Portanto, as vitaminas e os minerais têm função de regular, ajudar o organismo a funcionar.

As vitaminas podem ser divididas em dois grupos:

1) lipossolúveis: que são solúveis em lipídios e insolúveis em água. São absorvidas juntamente com as gorduras da dieta. São elas: A, D, E e K. 
2) hidrossolúveis: vitaminas solúveis em água. São normalmente excretadas pela urina em pequenas quantidades e não são armazenadas pelo organismo em grande quantidade, por isso é importante serem consumidas diariamente.

\begin{tabular}{|c|c|c|}
\hline VITAMINAS & FUNÇŌES & ALIMENTOS FONTES \\
\hline A (retinol) & $\begin{array}{l}\text { Essencial ao } \\
\text { processo visual, e } \\
\text { à formação dos } \\
\text { tecidos epiteliais e } \\
\text { da estrutura óssea. }\end{array}$ & $\begin{array}{l}\text { Fígado, leite integral, gema de } \\
\text { ovo, óleo de figado de } \\
\text { bacalhau, cenoura, abóbora, } \\
\text { batata doce, folhas verdes } \\
\text { escuras, melão, pêssego, } \\
\text { mamão, tomate. }\end{array}$ \\
\hline $\begin{array}{l}\text { D formada na } \\
\text { pele pela } \\
\text { exposição aos } \\
\text { raios solares }\end{array}$ & $\begin{array}{l}\text { Crescimento e } \\
\text { desenvolvimento } \\
\text { ósseo. }\end{array}$ & $\begin{array}{l}\text { Fígado, gema de ovo, óleos de } \\
\text { figado de peixes, leite, } \\
\text { manteiga. }\end{array}$ \\
\hline $\mathrm{E}$ (tocoferol) & $\begin{array}{l}\text { Proteção } \\
\text { membranas } \\
\text { celulares }\end{array}$ & $\begin{array}{l}\text { Oleos vegetais (soja, milho, } \\
\text { girassol), vegetais verdes, } \\
\text { gema de ovo, figado, frutas } \\
\text { oleaginosas. }\end{array}$ \\
\hline $\bar{K}$ & $\begin{array}{l}\text { Importante para } \\
\text { coagulação } \\
\text { sangüínea }\end{array}$ & Folhas verdes, figado. \\
\hline $\begin{array}{l}\text { C (ácido } \\
\text { ascórbico) }\end{array}$ & $\begin{array}{l}\text { Necessária para } \\
\text { funcionamento das } \\
\text { células, proteção } \\
\text { contra infecções. }\end{array}$ & $\begin{array}{l}\text { Laranja, tangerina, lima, } \\
\text { limão, morango, manga, caju, } \\
\text { goiaba, acerola. } \\
\text { Tomate, pimentão, couve }\end{array}$ \\
\hline
\end{tabular}

As vitaminas do Complexo B são auxiliares na regulação do metabolismo (funcionamento) do 
organismo. São encontradas nas carnes, ovos, leguminosas, vegetais verdes, cereais integrais.

Obs: a vitamina B12 é encontrada somente nos alimentos de origem animal.

\begin{tabular}{|c|c|c|}
\hline MINERAIS & FUNÇO์ES & ALIMENTOS FONTES \\
\hline Cálcio & \begin{tabular}{|lr} 
Formação & e \\
manutenção & de \\
ossos e dentes. & \\
Transmissão & de \\
impulsos nervosos \\
\end{tabular} & $\begin{array}{l}\text { Leites, queijos, iogurtes, } \\
\text { coalhadas, sardinha, manjuba }\end{array}$ \\
\hline Fósforo & $\begin{array}{l}\text { Interage com o } \\
\text { cálcio na formação } \\
\text { e manutenção de } \\
\text { ossos e dentes }\end{array}$ & $\begin{array}{l}\text { Queijos, gema de ovo, leites, } \\
\text { carnes, peixes, aves, castanha, } \\
\text { amendoim }\end{array}$ \\
\hline Magnésio & $\begin{array}{|lr|}\text { Essencial } & \text { na } \\
\text { sintese } & \text { de } \\
\text { proteinas e } & \text { na } \\
\text { transmissão } & \text { dos } \\
\text { caracteres } & \\
\text { hereditários } & \\
\end{array}$ & $\begin{array}{l}\text { Cereais de trigo integral, tofu, } \\
\text { castanhas, carnes, leite, } \\
\text { hortaliças verdes, legumes, } \\
\text { chocolates. }\end{array}$ \\
\hline Sódio & $\begin{array}{l}\text { Regula o equilibrio } \\
\text { de sais e água nas } \\
\text { células }\end{array}$ & $\begin{array}{l}\text { Sal de cozinha, alimentos } \\
\text { marinhos, leite, carnes em } \\
\text { geral, } \\
\text { industrializados com sal. }\end{array}$ \\
\hline Potássio & $\begin{array}{|lr|}\text { Equilíbrio } & \text { dos } \\
\text { líquidos no corpo. } \\
\text { Colabora } \\
\text { contração } \\
\text { muscular. } \\
\end{array}$ & $\begin{array}{l}\text { Frutas, leites, carnes, cereais e } \\
\text { hortaliças cruas. }\end{array}$ \\
\hline Ferro & 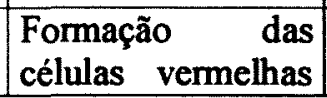 & $\begin{array}{l}\text { Fígado, carnes, folhas verdes } \\
\text { escuras (quando associadas à }\end{array}$ \\
\hline
\end{tabular}




\begin{tabular}{|l|l|l|}
\hline & $\begin{array}{l}\text { do sangue } \\
\text { (hemoglobina), } \\
\text { importante no } \\
\text { transporte de } \\
\text { oxigênio para os } \\
\text { tecidos. }\end{array}$ & \\
\hline lodo & $\begin{array}{l}\text { Regula função da } \\
\text { glândula tireóide. }\end{array}$ & $\begin{array}{l}\text { Sal de cozinha iodado, } \\
\text { alimentos do mar. }\end{array}$ \\
\hline Flúor & $\begin{array}{l}\text { Manutenção do } \\
\text { tecido ósseo, evita } \\
\text { cáries dentárias. }\end{array}$ & $\begin{array}{l}\text { Água fluoretada, espinafre, } \\
\text { cebola, alface. }\end{array}$ \\
\hline
\end{tabular}

FIBRAS - são tipos especiais de carboidratos, nem sempre digeridas pelo nosso organismo e têm como função auxiliar e regular o bom funcionamento do organismo. Existem dois tipos de fibras: solúveis e insolúveis.

Alimentos fontes de fibras:

frutas, hortaliças, leguminosas e cereais integrais.

ÁGUA - é um componente indispensável para a manutenção da vida, pois é o maior meio de transporte para os nutrientes e substâncias $\longrightarrow$ corpóreas, fazendo parte de todos os tecidos do corpo humano. $O$ corpo humano é composto de aproximadamente $60 \%$ de água.

Uma pessoa pode viver semanas sem alimentos, mas sobrevive poucos dias sem água. 
Todo o alimento, em menores ou maiores proporções contém água em sua constituição, mas a maior fonte, com certeza, é a água pura.

\section{CALORIA}

Caloria é a energia proveniente da combustão orgânica que os alimentos sofrem. Por isso, os alimentos mais calóricos são os mais energéticos.

Para calcularmos o valor calórico de cada alimento é necessário conhecermos suas proporções de carboidratos, lipidios e proteínas, pois as calorias são provenientes destes nutrientes.

Cada grama de carboidrato e de proteína correspondem a 4 Cal (calorias) e cada grama de lipídios (gordura) contribui com 9 Cal. Dessa forma, a gordura, com certeza, é o nutriente mais calórico.

0 valor calórico total (VCT) da alimentação diária deve ser distribuído da seguinte forma:

- Carboidratos: 50 a $60 \%$ do VCT

- Lipídios: 20 a $30 \%$ do VCT

- Proteínas: 10 a $15 \%$ do VCT

O ganho ou perda de peso estão diretamente relacionados d̀ ingestão de calorias. Se ingerirmos mais do que gastamos, essa caloria (energia) excedente ficará armazenada no organismo sob a forma de gordura. No entanto, se gastarmos mais 
calorias do que ingerirmos utilizaremos as reservas $e$ haverá perda de peso.

Todos os alimentos, com exceção da água, contêm calorias em menores ou maiores proporções. Não existe alimento que seja isento de calorias ou que faça perder peso.

\section{ALIMENTACÃO EQUILIBRADA}

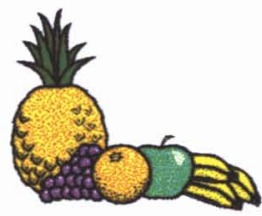

Para compor uma alimentação equilibrada, ou seja, que tenha potencialmente condições de fornecer os nutrientes necessários para o crescimento e a manutenção do organismo da criança, é preciso seguir três princípio básicos:

1- Alimentos de todos os grupos - escolher representantes de todos os grupos alimentares, possibilitando uma grande variedade de nutrientes necessários ao organismo.

2- Proporção adequada de alimentos - o organismo precisa de muitos nutrientes, porém não em quantidades iguais. É importante verificar a proporção adequada dos alimentos.

3- Variar ao máximo os alimentos - o conteúdo nutricional dos alimentos é muito variado, mesmo entre aqueles pertencentes ao mesmo grupo. Por isso, variar a ingestão de alimentos é uma 
estratégia importante para obter todos os nutrientes necessários.

\section{PIRÂMIDE ALIMENTAR}

Um método de orientação para equilibrar a alimentação é dado pela pirâmide alimentar. Nela, os alimentos são apresentados em seis grupos, de acordo com o seu nutriente principal.

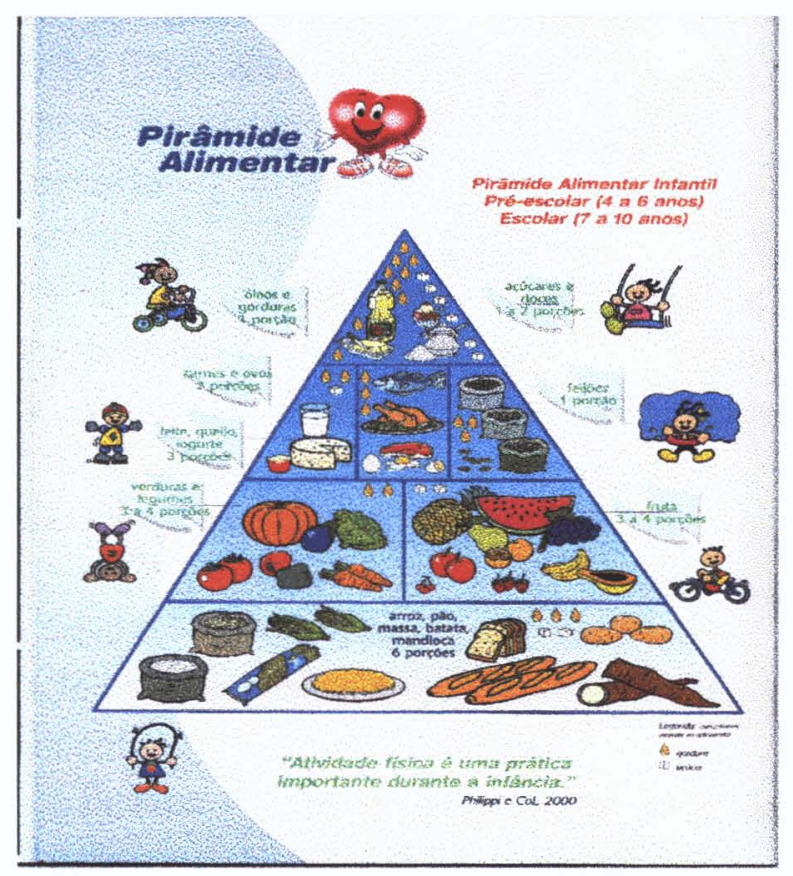


A pirâmide traz ainda a quantidade de porções. de cada grupo, que precisa ser ingerida diariamente. O tamanho da porção deve variar de criança para criança, dependendo do seu crescimento e atividade física.

GRUPO 1 - Base da pirâmide composta de alimentos do grupo dos carboidratos (cereais, massas, pães, raizes e tubérculos). Para que a criança tenha a ingestão adequada de energia, é preciso que sua alimentação diária seja composta de seis porções de alimentos desse grupo. Por exemplo:

Café da manhã - pão

Lanche - fubá (ingrediente do bolo)

Almoço - arroz e batata

Lanche - biscoito

Jantar - macarrão

ERUPO 2 - verduras e legumes - logo acima da base da pirâmide está um grupo menor, representado pelos legumes $e$ vegetais folhosos, que são fonte de vitaminas e minerais. A criança deve comer pelo menos três porções desses alimentos por dia. Por exemplo:

Lanche da manhã - cenoura batida no suco

Almoço - salada de alface e tomate

Jantar - brócolos no macarrão

ERUPO 3 - Frutas - este grupo está ao lado do das verduras e legumes, que também fornecem vitaminas 
e minerais. É conveniente que a criança coma três porções de frutas diferentes diariamente. Caso frutas in natura não sejam apreciadas, sucos, saladas de frutas e doces caseiros são boas opções.

GRUPO 4 - leite, queijo e iogurte fazem parte do grupo de alimentos que fornecem proteínas e também cálcio. $O$ ideal é que se consuma 3 porções diárias. Podem ser consumidos na forma natural ou em diversas preparações como purês, sorvetes, pudins $e$ outras preparações à base de leite.

GRUPO 5 - carnes e ovos - alimentos fontes de proteína animal além de ferro e vitamina B12. A recomendação diária é de 2 porções.

GRUPO 6 - Leguminosas (feijão, soja, grão-de-bico, lentilha, ervilha seca) - são alimentos fontes de proteína vegetal. Recomenda-se pelos menos uma porção diária.

GRUPO 7 - Gorduras e açúcar - este grupo está localizado no topo da pirâmide, e devem ser consumidos com moderação. Sua exclusão total da dieta não é recomendada. $O$ ideal é consumir até duas porções diárias, não se esquecendo de preparações que já contém óleos e açúcares como adição, por exemplo, bolos e frituras. 


\section{IMPORTÂNCIA DA HIGIENE NA ALIMENTACÃO}

A alimentação pode ser veículo de saúde ou enfermidade. Ainda que seja uma alimentação equilibrada do ponto de vista nutricional, se ela estiver contaminada com microorganismos prejudiciais à saúde, com certeza trará doença a quem consumir.

As bactérias são microorganismos atraídos pelos alimentos, principalmente os que contêm determinados nutrientes. A preferência da bactéria é pela proteína animal, presente nas carnes, ovos, leite e seus derivados, por isso é tão comum que esses alimentos se deteriorem quando não estão conservados adequadamente. Além disso, as bactérias preferem ambientes úmidos para sua multiplicação, dificilmente se desenvolvem em produtos desidratados.

Altas e baixas temperaturas também não atraem as bactérias. Multiplicam-se em temperaturas entre 10 e $60^{\circ} \mathrm{C}$. Por esse motivo, devemos controlar a temperatura na qual os alimentos são armazenados $e$ cozidos.

Algumas parasitoses também são transmitidas através de alimentos contaminados. Por isso é 
fundamental lavar bem as verduras $e$ frutas, deixando-as de molho no cloro ou vinagre para matar os microorganismos presentes.

A boa limpeza e manutenção do local onde são manipulados os alimentos é fundamental para que não atraia insetos e roedores, que também podem contaminá-los.

Por fim, as doenças também podem ser transmitidas pelas mãos de quem prepara os alimentos. É fundamental lavar sempre as mãos com sabão, principalmente depois de utilizar o banheiro, escovar os cabelos ou mexer no lixo.

\section{ALIMENTACÃO E SEUS EFEITOS PARA A SAÚDE}

A alimentação equilibrada é importante para manter a saúde, prevenindo o aparecimento de várias doenças.

Estudos recentes comprovam que a maioria das doenças está associada a hábitos alimentares errados. Vamos abordar algumas das doenças mais diretamente relacionadas a problemas nutricionais. 


\section{OBESIDADE}

A obesidade consiste no acúmulo excessivo de gordura no tecido adiposo, podendo ser um processo generalizado ou afetar mais intensamente certas partes do corpo humano.

Pode ser classificada como alimentar (ingestão alimentar excessiva associada d̀ baixa atividade física) ou constitucional (alguma alteração no funcionamento do organismo).

A obesidade é um dos importantes fatores de risco nas doenças cardiovasculares e está relacionada à alta prevalência de diabetes, hipertensão arterial e elevação dos niveis de colesterol, entre outras ocorrências.

Atualmente, o índice de obesidade entre a população vem aumentando em todos os niveis etários e sociais. Para as crianças, a obesidade representa um risco ainda maior para a saúde, pois, se não for controlada, haverá um maior contato do indivíduo com o distúrbio, além de os hábitos alimentares errados já estarem enraizados.

$O$ tratamento da obesidade mais recomendado é o dietético, através da reeducação alimentar, associado d̀ atividade física regular. Para isso, não é necessário suprimir alimentos da dieta, mas sim reduzi-los. Ainda que a criança esteja fazendo dieta 
para redução de peso, é importante que ela receba os mais variados alimentos para que não fique desnutrida, comprometendo o seu crescimento.

\section{DESNUTRIÇÃO}

A desnutrição pode ser definida como falta ou deficiência de nutrientes no organismo. Pode se dar em decorrência da ingestão escassa de nutrientes ou por deficiência metabólica (quando o organismo não absorve determinados nutrientes).

A desnutrição, principalmente nos primeiros anos de vida, prejudica o desenvolvimento físico e mental, podendo trazer seqüielas para o resto da vida do indivíduo.

$O$ indivíduo desnutrido apresenta basicamente: peso e altura abaixo do ideal para a idade, apatia, mucosas pálidas, como gengiva e parte interna das pálpebras, além da diminuição do tamanho da musculatura.

Para a recuperação do indivíduo desnutrido, é necessário um acompanhamento especializado para que o quadro não se reverta em obesidade, o que comumente acontece.

\section{ANEMIA FERROPRIVA}

É um distúrbio cuja causa é a carência de ferro no organismo. O ferro é um mineral que atua 
diretamente nas células sangüineas, ajudando no transporte de oxigênio para o organismo.

Acontece com frequiência na infância, com maior prevalência na criança em idade pré-escolar e pode estar diretamente relacionada da alimentação inadequada ou presença de parasitoses.

\section{CÁRIE DENTÁRIA}

A nutrição é um fator importante para a saíde dentária, desde a ingestão de alimentos que fortaleçam os dentes e gengivas até a composição de uma dieta e hábitos alimentares que diminuam a incidência de cáries. Crianças que consomem alimentos ricos em açúcar e pobres em fibras terão maior incidência de cáries.

Recomenda-se que o consumo de doces seja restrito ds refeições (como sobremesa), para diminuir a formação de cáries. Alimentos fibrosos auxiliam a retirar residuos alimentares dos dentes. Refeições em horários regulares evitam a fermentação constante dos resíduos na boca.

\section{DIABETES}

O Diabetes Mellitus ou simplesmente diabetes é definido como distúrbio metabólico, no qual o organismo é incapaz de metabolizar completamente 
os açúcares, devido à deficiência total ou parcial de insulina, hormônio produzido pelo pâncreas.

O diabetes pode levar a sérias alterações vasculares, como alterações nos rins, olhos $e$ manifestações precoces de aterosclerose, o que inclui fatores de risco de doenças cardiovasculares.

$O$ diabetes pode ser classificado em tipo I ou tipo II. $O$ do Tipo I (insulino-dependente) pode aparecer na infância, adolescência ou mesmo na idade adulta e caracteriza-se pela incapacidade do organismo de produzir insulina, tornando o indivíduo dependente da administração do hormônio. $O$ diabetes do tipo II ocorre geralmente na "idade madura" devido à diminuição na produção da insulina. É mais freqüente em indivíduos com excesso de peso.

De modo geral, o diabetes do tipo II pode ser controlado exclusivamente com a dieta ou associado ao uso de medicamento, o que será determinado pelo médico.

No controle alimentar, deve ser dada atenção especial da quantidade de carboidratos da dieta. A manutenção de uma dieta equilibrada é essencial para que o diabético possa melhorar sua qualidade de vida.

\section{HIPERTENSÃO ARTERIAL}

A hipertensão arterial é a elevação dos níveis normais da pressão sangüínea.

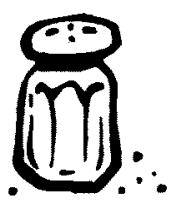


Existem diversos fatores que podem ser implicados como causa da hipertensão, entre eles está o consumo de sal, que habitualmente é ingerido em quantidades superiores às necessidades do organismo.

É importante ler com atenção os rótulos dos produtos industrializados, pois na maioria das vezes, mesmo sendo doces, contém sal.

\section{DISLIPIDEMIAS}

Dislipidemia significa alteração nos níveis de gordura no sangue. Os tipos mais comuns são: hipercolesterolemia e hipertrigliceridemia.

O colesterol é um tipo de gordura importante para o organismo, mas em quantidades elevadas no sangue, significa um risco aumentado para doenças cardiovasculares.

Os alimentos que devem ser consumidos com moderação, por conterem grande quantidade de colesterol são: gema de ovo, miúdos (fígado, rim, coração), frutos do mar (camarão), frios e embutidos (presunto, mortadela, salame, salsicha) e produtos à base de leite integral.

\section{CUIDADOS AO COMPRAR ALIMENTOS}

Já sabemos que os alimentos são os "carreadores" de nutrientes, por isso,

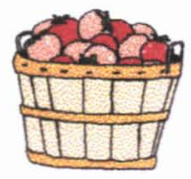


tão importante quanto a sua ingestão, é a escolha dos mesmos. Por isso, a qualidade e a aparência do que se deseja adquirir deve ser observada no momento da compra.

É importante saber onde comprar os alimentos, escolhendo estabelecimentos que mantenham uma boa apresentação das instalações e dos funcionários.

Portanto, fique atento ao comprar:

1- Frutas e hortaliças.

- No caso de frutas e verduras que se estragam facilmente, compre o suficiente para o consumo em poucos dias:

- Nunca compre frutas maduras demais, com partes moles, amassadas ou rachadas;

- As hortaliças (verduras e legumes) devem estar firmes, limpas, de cor e tamanho uniforme, sem folhas murchas ou amareladas:

- Compre frutas e hortaliças da época, pois são mais saborosas e nutritivas. Veja os quadros com as épocas de cada hortaliça.

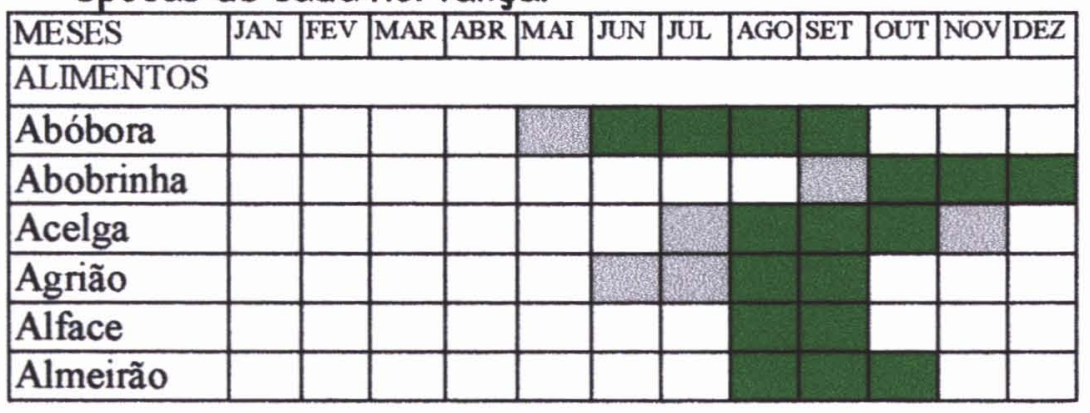




\begin{tabular}{|l|l|l|l|l|l|l|l|l|l|l|l|l|}
\hline Batata & & & & & & & & & & & & \\
\hline batata-doce & & & & & & & & & & & & \\
\hline Berinjela & & & & & & & & & & & & \\
\hline Beterraba & & & & & & & & & & & & \\
\hline Brócolos & & & & & & & & & & & & \\
\hline Cebola & & & & & & & & & & & & \\
\hline Cenoura & & & & & & & & & & & & \\
\hline Chicória & & & & & & & & & & & & \\
\hline Chuchu & & & & & & & & & & & & \\
\hline Couve & & & & & & & & & & & & \\
\hline couve-flor & & & & & & & & & & & & \\
\hline Escarola & & & & & & & & & & & & \\
\hline Espinafre & & & & & & & & & & & & \\
\hline Inhame & & & & & & & & & & & & \\
\hline Jiló & & & & & & & & & & & & \\
\hline Mandioca & & & & & & & & & & & & \\
\hline Mandioq. & & & & & & & & & & & & \\
\hline milho verde & & & & & & & & & & & & \\
\hline Pepino & & & & & & & & & & & & \\
\hline Pimentão & & & & & & & & & & & & \\
\hline Quiabo & & & & & & & & & & & & \\
\hline Rabanete & & & & & & & & & & & & \\
\hline Repolho & & & & & & & & & & & \\
\hline Salsão & & & & & & & & & & & & \\
\hline Tomate & & & & & & & & & & & \\
\hline Vagem & & & & & & & & & & & & \\
\hline
\end{tabular}


FRUTAS

\begin{tabular}{|l|l|l|l|l|l|l|l|l|l|l|l|l|l|l|l|}
\hline MESES & JAN & FEV & MAR & ABR & MAI & JUN & JUL & AGO & SET & OUT & NOV & DEZ \\
\hline ALIMENTOS & & & & & & & & & & & & \\
\hline Abacate & & & & & & & & & & & & & \\
\hline Abacaxi & & & & & & & & & & & & & & \\
\hline Banana & & & & & & & & & & & & \\
\hline Caqui & & & & & & & & & & & & \\
\hline Figo & & & & & & & & & & & \\
\hline Goiaba & & & & & & & & & & & & \\
\hline Jabuticaba & & & & & & & & & & & & \\
\hline Laranja & & & & & & & & & & & & \\
\hline Limão & & & & & & & & & & & & \\
\hline maçã & & & & & & & & & & & & \\
\hline Manga & & & & & & & & & & & & \\
\hline Mamão & & & & & & & & & & & & \\
\hline Maracujá & & & & & & & & & & & & \\
\hline Melancia & & & & & & & & & & & & \\
\hline Melão & & & & & & & & & & & & \\
\hline Morango & & & & & & & & & & & & \\
\hline Pêssego & & & & & & & & & & & & \\
\hline Tangerina & & & & & & & & & & & & \\
\hline uva niagra & & & & & & & & & & & & \\
\hline
\end{tabular}

Período de safra

2- Grãos e farinhas.

- Verificar, em primeiro lugar, a data de validade.

Não compre se estiver vencido; 
- Não compre quando a embalagem estiver rasgada, furada ou úmida ou quando no interior do pacote, notar a presença de insetos;

- Estes alimentos não devem apresentar cheiro ou gosto de mofo:

- A cor deve ser característica do alimento.

3- Carnes (aves, bovinos, suínos e pescados).

- As carnes devem ser compradas dentro do prazo de validade:

- A cor e o odor não devem estar alterados:

- As carnes não devem estar com aspecto pegajoso:

- Os pescados devem apresentar olhos brilhantes e salientes, escamas firmes, cheiro característico.

4- Ovos.

- Verifique a data de validade:

- A casca do ovo deve estar limpa e sem rachaduras.

5- Leites e derivados.

- Não consumir produtos fora do prazo de validade:

- O leite deve apresentar cor branca levemente amarelada, cheiro suave e gosto adocicado:

- As embalagens devem estar íntegras:

- A manteiga não deve ser consumida se sabor estiver alterado (ranço):

- Os iogurtes não devem ser consumidos quando odor e sabor estiverem alterados (muito ácido ou amargo) ou a embalagem estufada: 
- O requeijão não deve ser consumido se apresentar pontos de mofo, cor e odor alterados.

- Os queijos devem estar isentos de mofo, cor e odor característicos. Não deve apresentar aspecto pegajoso.

6- Enlatados.

- Não comprar latas que estiverem estufadas, amassadas ou enferrujadas;

- As latas não devem apresentar sinal de vazamento: molhadas ou meladas;

- Ao abrir a lata, verificar se cor, odor e aparência são característicos aos produtos.

7- Doces e tortas preparados.

- Verifique sempre a data de validade dos produtos preparados:

- Observar a temperatura de armazenamento, estes devem ser conservados a frio.

Considerações gerais:

- Conserve os alimentos em local seco, longe dos produtos de higiene e limpeza.

- Não use latas de tintas, cera, venenos ou sacos de lixo para armazenar alimentos.

- Ao fazer suas compras, deixe os produtos pereciveis por último. 
- Observe sempre as condições de higiene dos funcionários e do estabelecimento onde está fazendo suas compras.

- Atualmente, a maioria dos produtos industrializados possui um serviço de atendimento ao consumidor. Qualquer dúvida ou reclamação sobre o produto, não deixe de entrar em contato com a empresa. Este é um direito seu.

\section{COMO COMPORTAR-SE À MESA}

É importante transmitir às<smiles></smiles>
crianças regras da boa educação e dos bons modos à mesa. Isso não é sinônimo de opressão e nem visa tirar-lhes a espontaneidade e alegria de viver. As crianças sentem-se mais seguras quando as regras são claras e aplicadas especificamente, já a ausência de normas ou de limites causa-lhes desconforto $e$ insegurança. Além do mais, muitas regras de etiqueta que as crianças absorverem na hora das refeições serão importantes durante toda a sua vida, e em esferas que vão além da mesa.

ENSINE ÀS SUAS CRIANÇAS:

- Não falar de boca cheia, mastigando sempre com a boca fechada e sem fazer barulho.

- Nunca encher a boca demais a ponto de ficar com as duas bochechas com alimento. 
- Levar a comida novamente à boca quando esta já estiver vazia, da mesma forma, os líquidos.

- Fazer bolinhas com o miolo do pão parece ser divertido, mas é uma prática que não deve ser estimulada.

- Não apoiar a cabeça com as mãos e nem os cotovelos na mesa.

- O guardanapo de tecido deve ser desdobrado e levado ao colo. Já o de papel, deve ser mantido à mesa, do lado esquerdo do prato, sem ser amassado.

- Em uma mesa com muitos talheres, devem ser pegos de fora para dentro, à medida que a refeição for servida.

- A faca deve ser usada apenas para cortar os alimentos. Nunca deve ser levada à boca, pois pode machucar.

- Ao terminar de comer, deixar os talheres no prato, um ao lado do outro.

- Usar as famosas palavrinhas mágicas: obrigado (a), por favor, desculpe e com licença.

Obs: Crianças com 4 anos de idade já são capazes de manipular garfo e faca. 
Bibliografia consultada:

BRUZOS, SC. Educacion para la salud en la escuela, Ed. Diaz de Santos, AS. Madrid-Espanha, 1992.

CORNACCHIA, HJ: OLSEN, LK: NICKERSON, CJ. Health in elementary schools, $7^{\circ}$ ed. USA, 1988

CTENAS, MLB; VITOLO, MR. Crescendo com saúde - O guia de crescimento da crianca, Ed. Takano. São Paulo, 1999.

DOBLINSKI, S; RUIZ, AC. Não fale de boca cheia e outras dicas de etiqueta para crianças, ED. Mundo Cristão. São Paulo, 2001.

GENUTI - Grupo de Estudos de Nutrição na Terceira Idade - FSP/USP. Alimentagão na terceira idade, $2^{a}$ edição. São Paulo, 1998.

INSTITUTO DO CORAÇÃO - Serviço de Nutrição e Dietética - HC/FMUSP. VI Curso sobre cuidados nutricionais para prevenção e na presença de fatores de risco de doenças cardiovasculares: 
diabetes mellitus, hipertensão arterial, obesidade e dislipidemias, Quaker. São Paulo, 1999.

PHILIPPI, ST; RIBEIRO, LC; LATTERZA, AR; CRUZ, ATR. Pirâmide alimentar adaptada: guia para escolha de alimentos. R Nutr PUCCAMP, Campinas jan/abr, 1999;12(1):65-80.

PORTO, F. Nutrição para quem não conhece nutrição, Ed. Varela, São Paulo, 1998.

RIBEIRO,E; EISENSTEIN,E. Falando em saúde para criangas, adolescentes e educadores nas escolas e comunidades, Ed. Vozes. Rio de Janeiro, 1990.

SECRETARIA DE AGRICULTURA E ABASTECIMENTO. As quatro estações da alimentação, Governo do Estado de São Paulo, IMESP. São Paulo, 1995. 
Anexo 6

ANEXO 6 


\section{JOGO DA MEMÓRIA}

Consiste na montagem de pares de figuras diferentes. De acordo com a faixa etária, aumenta-se o nível de dificuldades com o aumento do número de cartões, a complexidade das figuras e a proposta escolhida como tema do jogo.

\section{O JOGO}

Todos os cartões serão colocados com a parte desenhada voltada para baixo, num arranjo feito em colunas para facilitar a memorização. Cada jogador deverá levantar dois cartões, olhá-los e recolocá-los no seu lugar. Assim é feito até que alguém consiga levantar um par, e então este jogador retira as peças do jogo e as mantém em seu poder; quando um jogador acerta um par, tem o direito a mais uma jogada. $O$ jogo termina quando são retirados da mesa todos os cartões, contando-se então o número de cartões de cada participante. Vence o jogo quem conseguir o maior número de cartões.

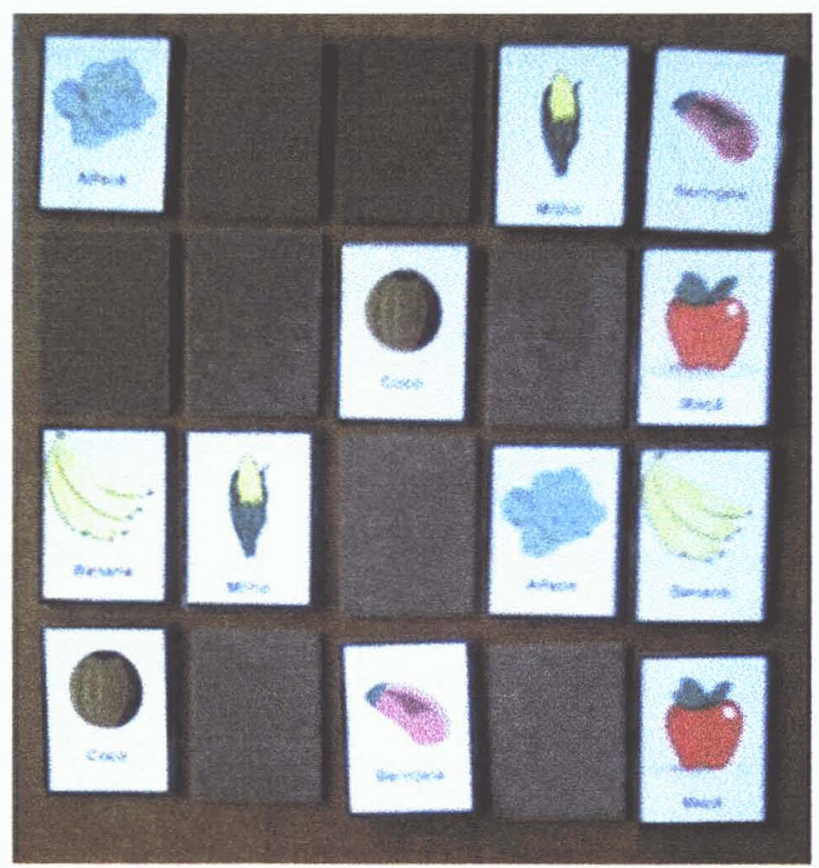




\section{JOGO DAS ADIVINHAÇÕES}

Cartões com figuras de mesma classe.

Como sensibilização, pode-se contar para a criança uma historinha com alguns elementos do jogo.

O número de participantes pode ser de dois a quatro. Para jogar, deixa-se os cartões empilhados com as figuras voltadas para baixo. Cada participante deverá retirar uma das figuras e, sem que os outros vejam, terá de responder sim ou não às perguntas, dando assim pistas para que adivinhem qual o cartão retirado.

Exemplo: - É folha?

- É fruta?

- Tem que cozinhar para comer?

Dessa forma, cada vez que um participante acerta, toma posse do seu cartão. O vencedor será aquele que tiver o maior número de cartões quando esses terminarem.
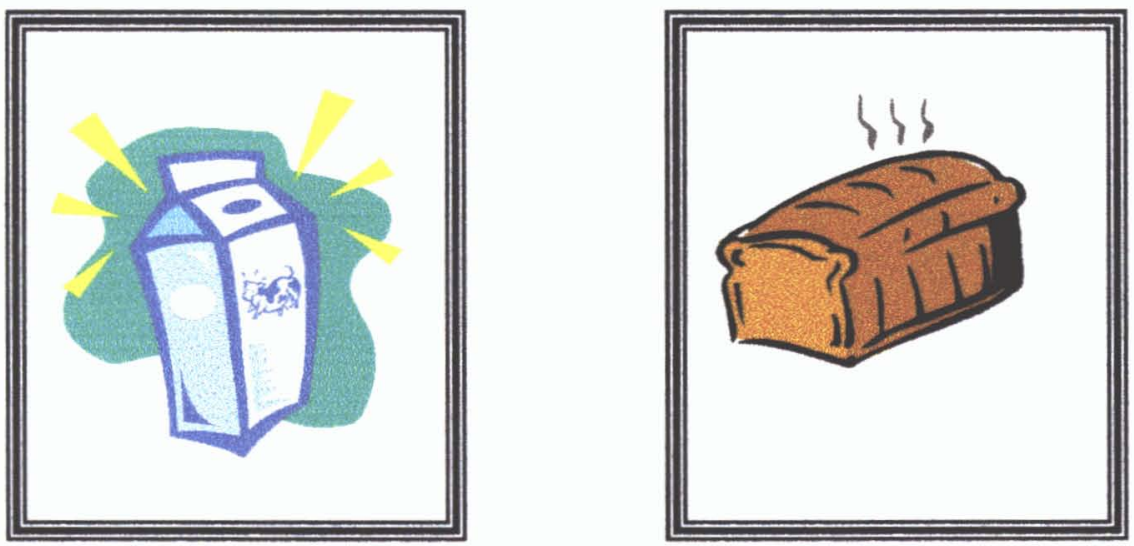


\section{DOMINó}

Este jogo pode ser jogado individualmente ou em duplas. O número de participantes pode ser de dois a quatro. Cada participante ou dupla recebe 7 peças e as mantém em segredo. O primeiro participante coloca na mesa uma peça que contenha a mesma figura dos dois lados e em seguida, cada participante na sua vez acrescenta uma peça com figura similar a uma das extremidades do jogo que está sobre a mesa. Aquele que não tiver uma das peças das extremidades passa a vez para o próximo participante Vence aquele que primeiro terminar com as peças recebidas no início do jogo.

Contendo 28 peças arranjadas de forma linear, deve manter a estrutura do jogo original:

$\begin{array}{lllllll}0.0 & 1.1 & 2.2 & 3.3 & 4.4 & 5.5 & 6.6 \\ 0.1 & 1.2 & 2.3 & 3.4 & 4.5 & 5.6 & \\ 0.2 & 1.3 & 2.4 & 3.5 & 4.6 & & \\ 0.3 & 1.4 & 2.5 & 3.6 & & & \\ 0.4 & 1.5 & 2.6 & & & & \\ 0.5 & 1.6 & & & & & \\ 0.6 & & & & & & \end{array}$

De acordo com a faixa etária, aumenta-se o nível de dificuldades com a complexidade das figuras e informações, alterando-se o tamanho das peças do jogo.
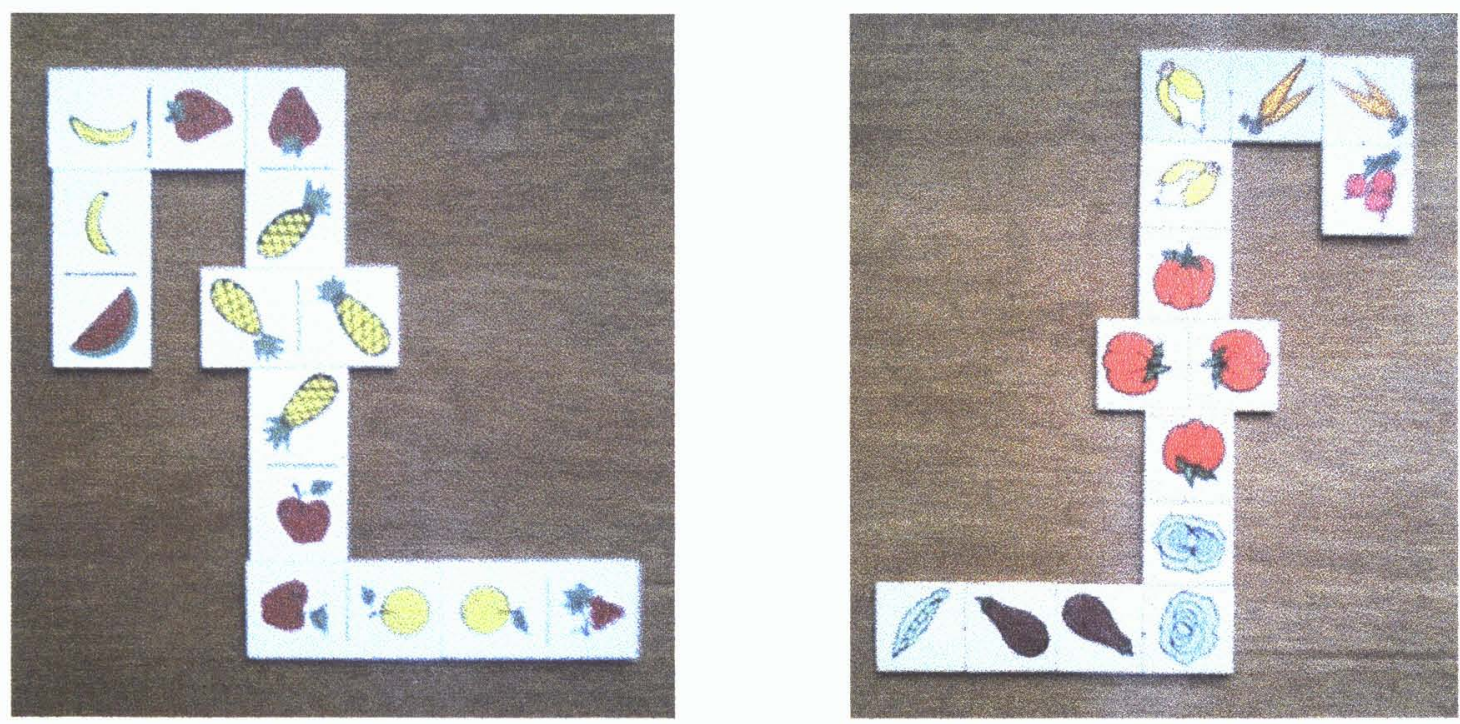


\section{QUEBRA-CABEÇA}

O quebra-cabeça pode ser confeccionado de diversas formas, com aplicações em diferentes áreas e com objetivos distintos.

As peças são embaralhadas e o objetivo é encaixá-las de modo que obtenha-se uma figura com formas definidas. Pode ser jogado individualmente ou em grupos.

$\mathrm{O}$ interessante deste jogo é proporcionar um momento de discussão sobre a figura a ser descoberta. Podem ser levantadas perguntas que sugiram situações de aprendizado sobre alimentos. Como por exemplo:

1- Qual o nome deste alimento?

2- Características sensoriais: doce ou salgado, azedo ou amargo.

3- Qual a origem deste alimento? Vegetal ou animal?

4- Qual a importância deste alimento? Fornece vitaminas, proteínas, minerais?

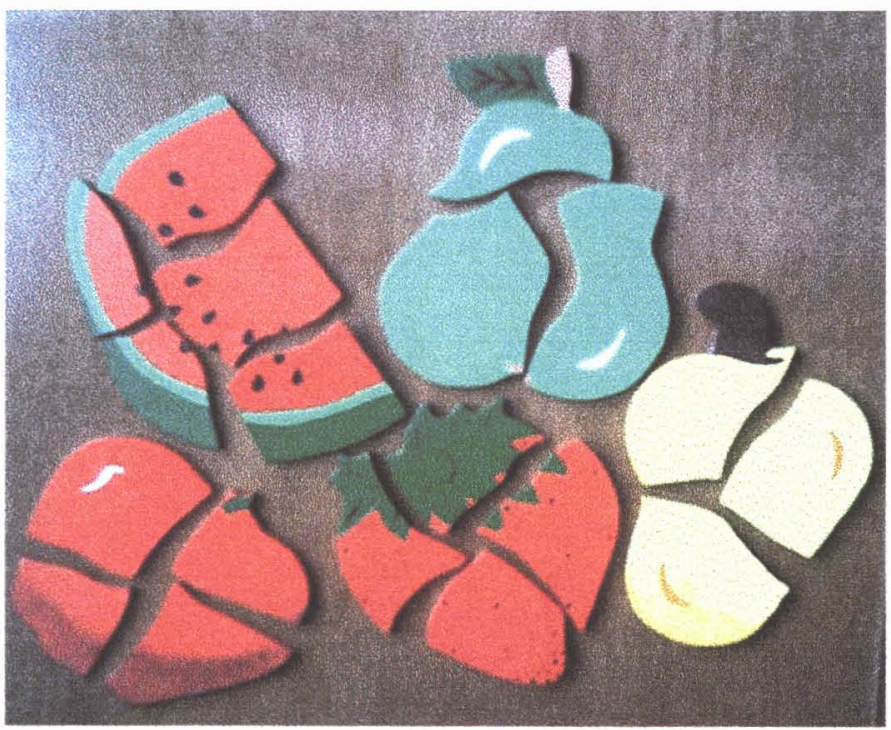


ANEXO 7 

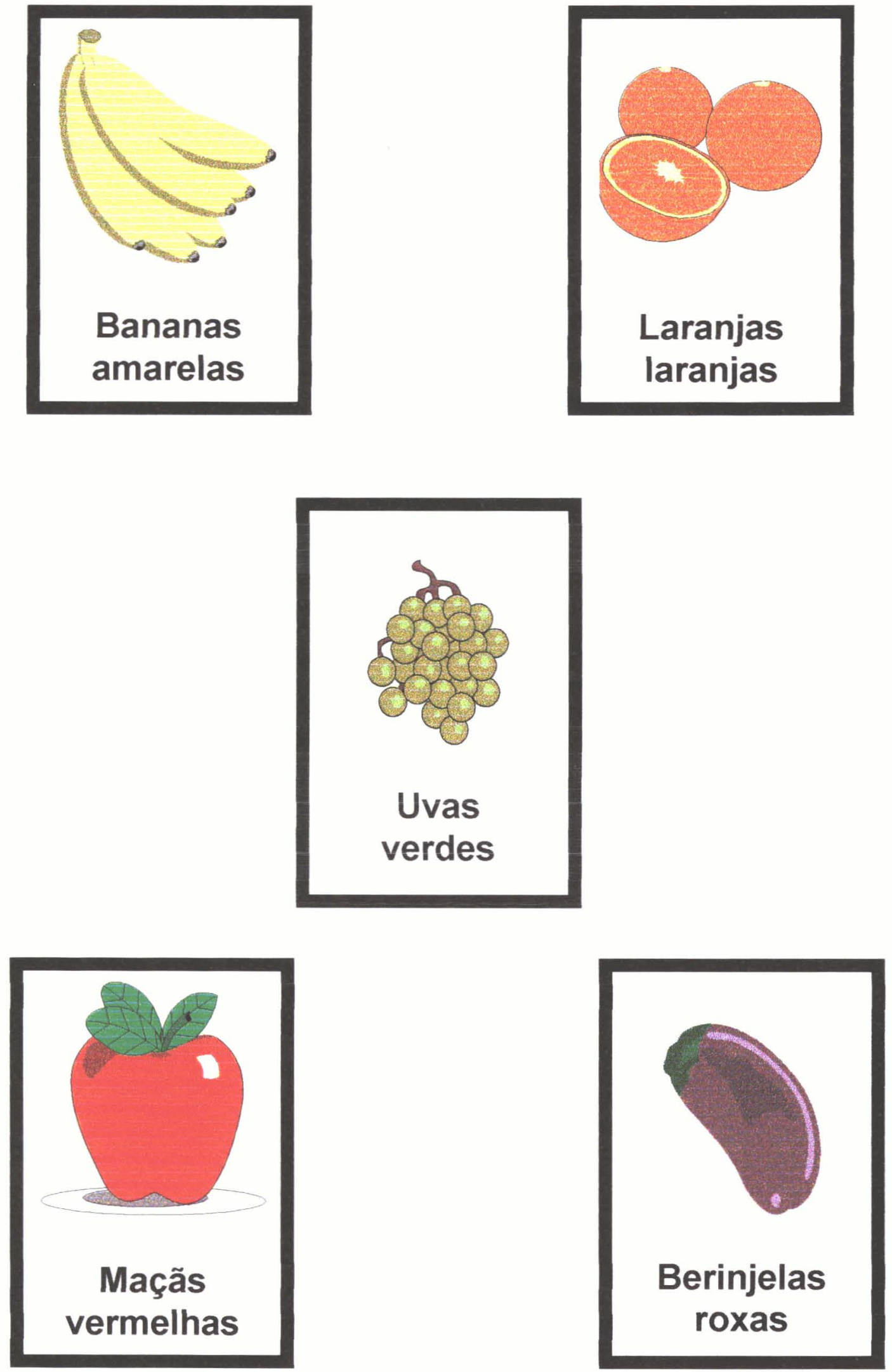
ANEXO 8 


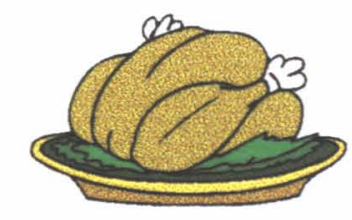

\section{ALMOÇO}

ARROZ

MACARRÃO

BATATA COZIDA

BIFE CEBOLADO

BOLINHO DE LEGUMES

FRANGO À PASSARINHO

BERINJELA PARMEGIANA

SALADA DE MAIONESE

SOPA DE FEIJÃO

TORTA DE FRANGO
FEIJÃo

SALADA DE FOLHAS

CARNE ASSADA

FRANGO ASSADO

SOPA DE MACARRÃO

FOLHA REFOGADA

bANANA À MILANESA

CREME DE MILHO

FEIJOADA

ARROZ COM LEGUMES 
ANEXO 9 


\section{CAFÉ DA MANHÃ}

CAFÉ COM LEITE

LEITE COM CHOCOLATE

VITAMINA DE FRUTAS

CEREAIS

PÃo

MARGARINA

REQUEIJÃO

QUEIJO

PRESUNTO

OVO QUENTE

PATÊ dE FRANGO

SUCO DE FRUTAS

PÃO dE QUEIJO

BOLO DE FUBÁ

GELÉIA DE FRUTAS

TORRADA

BISCOITOS

CHÁ

IOGURTE

MINGAU DE AVEIA 
ANEXO 10 


\section{OBESIDADE NA INFÂNCIA E ADOLESCÊNCIA}

\section{Por Rodrigo Moreira - médico endocrinologista}

Nos últimos anos, estudos em todo o mundo vêm evidenciando um aumento crescente na prevalência da obesidade na infância e adolescência. Por estes motivos, tem-se dado cada vez mais importância as características de tais crianças, já que a obesidade está ligada tanto a problemas imediatos como futuros.

Dentre as conseqüências mais imediatas estão: a ocorrência de inúmeras anormalidades ortopédicas, o aumento da incidência de asma brônquica (ainda que não totalmente caracterizado), múltiplas desordens do sono, litíase biliar ("cálculo na vesícula") além, é claro, de desordens endócrinas, como irregularidades menstruais, Diabetes Mellitus e até mesmo hiperandrogenismo (que leva a sinais de virilização, tais como o aparecimento de pêlos masculinos).

Existem também problemas psicológicos decorrentes da obesidade infanto-juvenil. Em alguns estudos com o objetivo de avaliar as características psicológicas e crianças obesas, verifica-se que elas são comumente descritas como sendo mais preguiçosas, "bobas", feias e até mesmo estúpidas, sendo consideradas como "os amigos mais indesejáveis". As conseqüências imediatas de tal discriminação muitas vezes acarreta alterações na auto-estima e comportamento, o que pode levar a doenças como a desnutrição e atraso de crescimento causados por uma diminuição extrema da alimentação ("medo da gordura")

Não é apenas nos adultos que a obesidade está ligada a alterações cardiovasculares; crianças e adolescentes também tem um risco aumentado para o desenvolvimento de tais alterações metabólicas, incluindo infarto agudo do miocárdio, acidente vascular cerebral ("derrame"), alguns tipos de câncer e insuficiência renal, entre outros. Quanto mais obesa a criança, maior a probabilidade dela se tornar um adulto obeso; quanto mais obesa a criança, mais obeso será 0 adulto.

Um dos principais fatores relacionados ao aumento da obesidade na infância e adolescente é decorrente de um aumento na ingesta calórica associado a uma diminuição no grau de atividade física. Inúmeros trabalhos já demonstraram que nos últimos anos tem havido uma diminuição progressiva da atividade fisica (uma criança americana assiste uma média de 24 horas semanais de televisão, sem contar ainda os jogos eletrônicos e os computadores, principalmente a internet), na maioria por parte das meninas.

Já foi comprovado que a própria qualidade dos hábitos alimentares dos pais é um fator importante no desenvolvimento da obesidade nas crianças. Entretanto, é de se esperar que a preocupação cada vez maior com a "forma física" e estética da sociedade moderna 
possa levar a uma melhora dos padrões alimentares dos adultos e, conseqüentemente, venha apresentar repercussర̃es futuras positivas.

Deste modo, qual seria a forma mais eficiente para reconhecer e, se necessário, tratar as crianças com risco aumentado para a obesidade? Inúmeras estratégias vem sendo propostas e cada qual com características e resultados diferentes.

A mudança no comportamento da criança em casa, deve ser considerado passo primordial. Não apenas a mudança dos hábitos alimentares por parte dos pais, mas também a conscientização de que tais mudanças são os fatores mais importantes para a manutenção de um peso saudável. A criança deve ser reeducada e ensinada sobre o valor e a necessidade de cada alimento e não ser imposta a uma dieta, o que invariavelmente levará a transgressões freqüentes e a falta de aderência.

A disponibilidade em casa de produtos industrializados (a sua maioria doces) ao invés de produtos naturais (frutas) deve ser evitada. Hoje em dia, a existência de propaganda maciça em cima de produtos industrializados, na sua maioria hipercalóricos e de baixo valor nutritivo, pode ser considerada um dos fatores agravantes desta nova epidemia mundial.

As escolas também constituem um determinante importante para as ações a serem tomadas na tentativa de se reduzir o problema. Nenhuma outra instituição tem um contato maior com a criança dos seus 7 aos 15 ano. Sua estrutura permite a elaboração de programas de educação baratos e com a participação de profissionais (professores e educadores) com habilidade par propiciar um aprendizado contínuo e eficiente.

A necessidade da reeducação alimentar deve contar com apoio da escola não apenas na regulação da "merenda escolar" servida (que se supõe ser sempre bem elaborada e balanceada), mas também na orientação e fiscalização dos lanches a que as crianças estão expostas nos intervalos de aulas. Além disso, 0 incentivo e a prática de atividade física deve ser estimulada e orientada por profissionais qualificados, inclusive com orientação constante para pais e professores.

Ainda não existe uma solução definitiva para o problema da obesidade na infância e adolescência. Entretanto, muito já se conhece sobre suas características de tal modo que medidas menores, porém igualmente efetivas, possam ser tomadas para controlar o problema. Mais do que um simples problema médico, a obesidade infanto-juvenil deve ser encarada considerando também suas repercussões sócio-econômicas e para tal necessita de conscientização e apoio de toda a sociedade.

Fonte: www.emagrecimento.com.br - 23/03/01 
ANEXO 11 


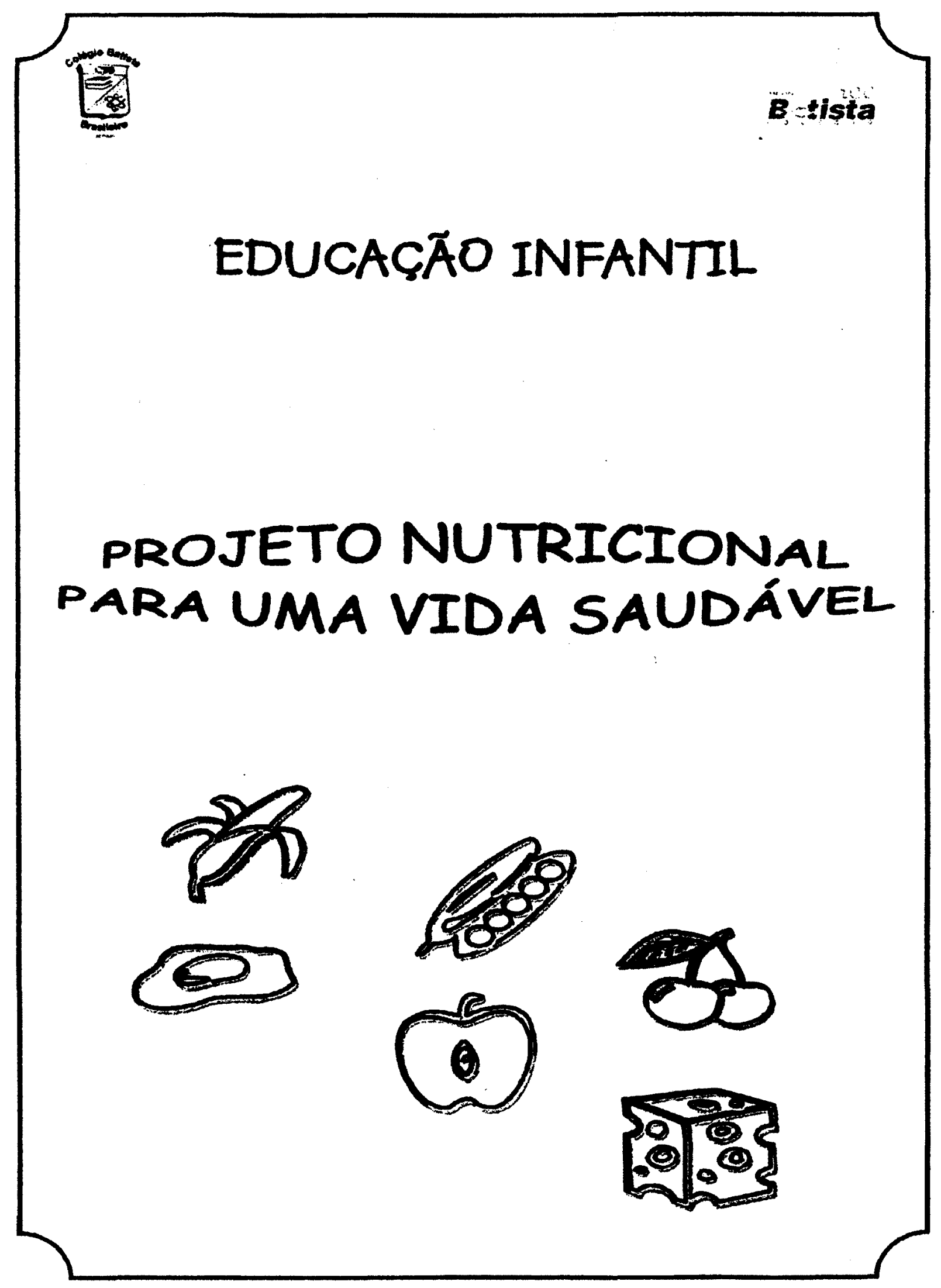




\section{JUSTIFICATIVA}

Os bons hábltos alimentares são estabelecidos desde a infância. portanto, para a aquisição de tais hábitos, a familla exerce um papel fundamental, pois é nela que serão estabelecidos os padrões allmentares que perdurarão para toda vida. Por isso, é importante assegurar d̀s crianças, uma dieta tão variada quanto possivel. Uma dieta que inclua multos nutrientes e sabores diferentes, assim como texturas e cores, nảo só assegurará que a nutrição e o desenvolvimento sejam adequados, mas também estimulará a capacidade de fazer escolhas adequadas entre diferentes alimentos.

Outro fator de grande impacto na formação do hábito alimentar da criança é a propaganda, particularmente a transmitida pela televisão. No decorrer de um ano, uma criança passa mais tempo assistindo $N$, do que na escola, por isso, a criança representa atualmente uma audlência significativa, tornando-se um dos principais alvos da propaganda. Uma proporção considerável de anúncios estimula as crianças a consumirem alimentos cujo valor nutritivo é limitado; eles têm alto teor energético $\theta$ tipicamente contêm grandes quantidade de gordura lespecialmente gorduras scruradas), açúcar, colesterol e sal e fornecem pouco ou nenhum nutriente.

Hoje, a escola assume um papel importante na formação integral do educando, incluindo a aquisição de bons nábitos alimentares. Deve-se destacar que o desenvolvimento social e psicológico da criança depende de uma boa nutrição e da interação com os pais e com o meio social na qual ela vive.

Este projeto, portanto, tem por objetivo conscientizar pais, educadores e educandos sobre a importância de uma educoção alimentar adequada, na busca de uma melhor qualidade de vida. Será desenvolvido com as crianças nos meses de abril a junho de 2001, com a sua demonstração na Mosta do Conhecimento. Desde o Maternal até o Infantil III, cada nivel estará trabalhando com autonomia, estabelecendo seus objetivos e realizando as atividades de acordo coma as necessidades e 


\section{OBJETIVOS}

\section{MATERNAL I E II}

$\checkmark$ Adotar hábitos de auto-cuidado, valorizando atitudes relacionadas à higlene pessoal e dos alimentos.

$\checkmark$ Conhecer a importância de uma alimentação saudóvel para a saúde pessoal; manipular, explorar e degustar diferentes alimentos.

\section{INFANTIL I}

$\checkmark$ Possibilitar às crianças oportunidades que propiciem o acesso e conhecimento sobre os diversos alimentos, o desenvolvimento de habilidades para escolher sua alimentaçāo, senirse e alimentar-se com segurança, prazer e independêncla.

$\checkmark$ Adquirir hábitos saudóveis de alimentaçāo, ou seja, ingerir alimentos que contenham os nutrientes que são necessários para manutenção da vida e saúde.

$\checkmark$ Integrar o Projeto Educação Nutricional com outras áreas do conhecimento: Natureza e Socledade (órgäos dos sentidos; reino vegetal e animal), Matemática, Linguagem Oral, Movimento, Attes Visuais e Música.

\section{INFANTIL II}

$\checkmark$ Conhecer, de forma singular as propriedades dos alimentos, alvidindo-os em trés grupos: Constutores / Energéticos / Reguladores.

$\checkmark$ Saber allmentar-se de forma variada e equilibrada, para um desenvolvimento saudável.

$\checkmark$ Conhecer formas de conservação dos alimentos, cuidados do prepard́-los e objetos para manipulá-los com higiene.

$\checkmark$ Preparar allmentos para degustá-los (lovar saladas e frutas, juntar os ingredlentes descritos nos rótulos das embalagens).

$\checkmark$ Organizar os alimentos próprios para as refeiçōes: café da manhã, almoço, lanche e jantar.

$\checkmark$ Observar a classificaçāo que é feita no supermercado para uma organização das compras e conservação dos allmentos.

$\checkmark$ Selecionar, dentre vários itens, aqueles que fazem bem para saúde.

$\checkmark$ Conhecer um pouco dos nossos órgöos intemos, as suas necessidades lágua, fibras, vitaminas, proteínas, cálcio) e onde encontramos nos allmentos. 
INFANTIL III

$\checkmark$ Compartilhar novas formas e novos sentidos para $\circ$ ato de comer, valorizando a importáncia da alimentação e reconhecendo as funçð̄es dos vários tipos de alimentos para desenvolvimento do corpo, de maneira saudóvel e equilibrada.

$\checkmark$ Reconhecer, identificar e classificar diferentes tipos de alimentos.

$\checkmark$ Aprender a conservar adequadamente os alimentos, observando data de validade, higienizaçāo e manuseio correto dos procutos naturais e industrializados.

$\checkmark$ Adquirir hábitos allmentares saudáveis e colocá-los em prática no cotidiano.

$\checkmark$ Descobrir novas possibilidades cullnárlas, reciclando os alimentos. 


\section{DESENVOLVIMENTO}

\begin{tabular}{|c|c|}
\hline \multicolumn{2}{|c|}{ MATERNAL I E II } \\
\hline $\begin{array}{l}\text { CONTEÚDOS } \\
2^{\circ} \text { TRIMESTRE } \\
\text { Boa Alimentoçāo }\end{array}$ & $\begin{array}{l}\text { ATIVID ADEs } \\
\text { Músicas e histórias que mostrem a importância das frutas e verduras na } \\
\text { alimentaçāo. } \\
\text { Classiflcação de embalagens de alimentos de acordo com sua } \\
\text { importância para a saúde. } \\
\text { Cartaz do lanche: observaremos a varledade do lanche e o quanto } \\
\text { cada criança comeu. } \\
\text { Salada de futas / saloda de verduras e legumes. }\end{array}$ \\
\hline $\begin{array}{l}\text { CONTEÚDOS } \\
2^{\circ} \text { TRIMESTRE } \\
\text { Higiene dos alimentos }\end{array}$ & $\begin{array}{l}\text { ATIVIDADES } \\
\text { Visita da cozinha da escola, com dermonstração da higienização dos } \\
\text { alimentos, feita pela nutricionista. } \\
\text { Dramatização com frutas e verduras de brinquedo, lavando-as } \\
\text { corretamente. } \\
\text { História } \theta \text { dramatização da higiene pessoal antes de prepararmos os } \\
\text { alimentos (lavar as mäos, prender os cabelos....) }\end{array}$ \\
\hline $\begin{array}{l}\text { CONTEÚDOS } \\
2^{\circ} \text { TRIMESTRE } \\
\text { Conservoçõo dos } \\
\text { Alimentos }\end{array}$ & $\begin{array}{l}\text { ATIVIDADEs } \\
\text { Brincadeira de supermercado, enfatizando a valldade e conservaçāo } \\
\text { dos allmentos. }\end{array}$ \\
\hline $\begin{array}{l}9 \text { DE JUNH1O } \\
\text { Projeto Educacional } \\
\text { para uma vida } \\
\text { Saudável. }\end{array}$ & $\begin{array}{l}\text { ATIVIDADES } \\
\text { Mostra do Conhecimento }\end{array}$ \\
\hline
\end{tabular}

INFANTIL I CONTEÚDOS

\section{DE ABRIL}

REINO VEGETAL

Partes da planta

Cuidados com o solo (terra boa, água, luz)

Discriminação visual e auditiva

\section{DE ABRIL}

Raiz: Mandloca

Alimento dos índios

Coordenação motora - fina

\section{DE ABRIL}

Índio (brincadeiras, moradia, vestimenta) Localizaçāo espacial; coordenaçāo visomntron

\section{ATIVIDADES}

Conversa informal lassim como o corpo, as plantas também têm partes; culdodos necessários para o desenvolvimento das plantas):

Versinho "Sementinha de Flor";

Plantar feljäo.

|Literatura Infantll: Hortolândla - "Dida, a mandloca":

Pintura a dedo: Cocar do indlo;

Desenho Live em grupo (papel kraft).

Conversa informal: 0 índio;

Confecção da tanga do índlo;

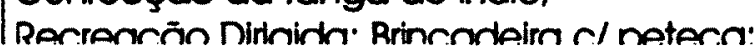


CONTEÚDOS

19 DE ABRIL

"Dla do índlo"

Dramatização / jogo simbólico

\section{ATIVIDADES}

Literatura Infantll: "O menino da Floresta" Músicas: $O$ indlo mora na floresta; $O$ índio mora no mato; 1,2,3 indiozinhos;

Dramatização - Passeio na Floresta.

20 DE ABRIL

Coordenação motora-fina

Conversa informal/ Cânticos e versinhos Modelagem

23 DE ABRIL

REINO VEGETAL

Partes da planta (observação do feljão, com

água es/ água)

Alimento: Batata

Linguagem oral

26 DE ABRIL

REINO VEGETAL

Partes da planta

Alimento: Cenoura

Discriminação auditiva

\section{DE ABRIL}

REINO VEGETAL

Partes da planta

Alimento: alface/verduras

\section{DE MAIO}

Passelo ao Supermercado (compras)

Higiene dos allmentos

Aprender bons hábitos alimentares;

Organtzação do pensamento; linguagem oral - texto coletivo

\section{DE MAIO}

REINO VEGETAL

Partes da planta - tronco

\section{DE MAIO}

Partes da planta: Tronco

Alimento: Cana de açúcar (caldo de cana, Literatura Infantil - açúcar;

rapadura, mascavo, reflnado) plantlo, Versinho açúcar;

colheita, processo de industrializaçāo e doces

Higiene bucal

\section{E 16 DE MAIO}

Partes da planta: Folhas, frutos e flores |Conversa informal;

Tipos de frutas; nome das ávores (macieira, Música das frutas;
Literatura Infantll: Hortolândia - "Beta Batata" Conversa informal (Quem gosta de batata ?) Versinhos: "Batatinha quando nasce ... ." "Sementinha de Flor"

Literatura Infantil: Hortolándla - "Nora, a Cenoura"
Conversa Informal a respeito da história e sobre o
alimento;
Experimentar ou degustar um pedaço de
cenoura crua;
Música: Cenourinha . . . vou comer / Batatinha
vou comer

Conversa informal (Quem sabe o que é verdura? Quem gosta de alface ?)

Literctura Infantil: Hortolândia: "Tafo, o Alface"

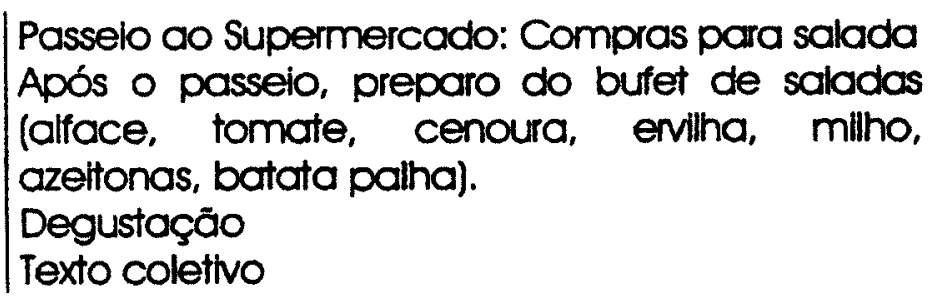

Conversa informal;

Passelo e observaçāo das árvores do jardim tronco (espessura, tamanho). 
21 E 22 DE MAIO

REINO VEGETAL - Frutas "banana"

Conversa informal, observaçāo da bananeira

no pótlo;

Versinho da banana;

Literatura infantil - "Nana banana".

Alimento: Banana

Versinho: Banana;

Matemática: cheio/vazio/muito/pouco/

Confecção do bolo de banana (alimentação e

quantificação

matemática) degustação.

\section{DE MAIO}

REINO VEGETAL

Partes da planta

"Coqueiro / fruto = coco / forma clrcular

linguagem oral (versinho/música)

discriminaçōo visual/matemática: tamanho -

alto / balxo; grande / pequeno

Coordenação motora - fina (bolinha de crepom)

\section{DE MATO}

Partes da planta: fruta - mamão

Coordenaçáo motora - fina

\section{DE MAIO}

Linguagem oral; produção do texto colettvo Observar, nomear e saborear diferentes tipos de frutas

\section{DE JUNHO}

REINO ANIMAL

Mamíferos, classifícação: pelos, patas

Exemplos de animals mamíferos

Músicas

\section{DE JUNHO}

REINO ANIMAL

Mamíferos

Classificação, importáncia para o homem

Alimentação - Ex.: a vaca nos dá lelte, do leite se faz quello, mantelga, etc.

Bol - carne, porco = llngüiça, salsicha $\ldots$

\section{DE JUNHO}

Alimentação nutritiva - "Dia do lelte el derivados"

\section{DE JUNHO}

Projeto Educaçõo Nutticional

\section{DE JUNHO}

REINO ANIMAL - Aves

Classificação (pena, bico, asas . . .)

Tipos de oves

Discriminação visual: Livro "Aves"
Conversa informal llogo do adivinha /

o que é, o que é ?):

Versinho / música do coco;

Observação do coqueiro (figuras e no jardim do CBB);

Attvidade: amassar e fazer bolinhas de crepom (coco). pintar o coqueiro e colar os coquinhos.

|Literatura infantil: "Bambão Mamão":
Conversa intormal;
Plntura a dedo - Máscara de frutas.

Conversa informal, versos e músicas;

Observar, nomear e saborear diferentes típos de frutas, salada de frutas;

Particlpar do texto colettvo sobre Reino Vegetal.

Conversa informal sobre os animais mamiteros, gromuras IVro "mamíferos";

Múskeas, porquinho, covallnho ...

Conversa informal: importância para o homem: Pesquisa em revistas;

História inventada la partir de uma cena com um animal mamífero, as crianças criam uma história).
Participar, nomear, saborear e conhecer a
importância do lelte e seus derivados, para a
nossa saúde.

| Mostra do Conhecimento

Conversa informal - aves (classificação)

Músicas: Eu tenho um patinho, Galinha magricela;

Verso: A galinha do vizinho. 


\section{A 18 DE MAIO}

Trajeto do allmento no Organismo

\section{A 25 DE MAIO}

Arumação e conservação dos Allmentos

28 DE MAIO A 1 DE JUNHO

Escolha e elaboração de allmentos noturais e saudóveis

\section{A 9 DE JUNHO}

Projeto Educaçōo Nutricional
Deitar uma criança no papel Kraft e representar através de desenho, os nossos órgãos intemos mostrar o trajeto que os alimentos fazem e como são depositados ou elliminados do organismo. Aula no laboratório de Clênclas com boneco. Aula na Informática Educativa - movimento do corpo humano.

Montar no verso do boneco de Kraft, o rosto e o corpo com alimentos recortados da revista. Comprar um lanche equillbrado na cantina. Calcular o valor dos alimentos (preço).

Montar uma cozinha com brinquedos e caixas de papelão.

Arrumaçäo com sucatas

Tomar o lanche na cozinha e colocar o restante dos alimentos nos lugares certos para conservação e limpeza.

Conversar sobre os objetos e o que fazemos na cozinha.

Comidas típicas de nossa cultura.

Visita ao Supermercado; compra de ingredlentes para uma salada e um suco natural. Observação da data de valldade.

Seleção e revelação dos nomes dos amigos secretos - chocolate.

Elaboração de quadrinhos com allimentos.

Bolachas $\theta$ grãos para Mostra do Conhecimento.

Fazer allmentos de massinha para brincar na Mostra do Conhecimento.

Arumação da sala com aparelhos de ginástica (alimentos energéticos) e degustação.

2 cantos para os demais grupos de allimentos: construtores: tijolinhos e degustação;

reguladores: degustaçāo e caminho do aparelho digestivo;

Demonstração do Projeto na Mostra do Conhecimento. 
INFANTIL III CONTEÚDOS

\section{MARÇO}

Aniversário do CBB

Alimentação variada

\section{MARCO}

Iníclo do Outono/vitaminas

\section{ATIVIDADES}

Bolo, päes com queijo e presunto e doces organizados em forma de festa. Podemos comer de tudo, com moderação.

Salada de frutas

Roda de conversa

\section{ABRT/MAIO}

Alimentos reguladores - o benefício para o intestino e para a pele.

\section{MAIO (2॰ SEMANA)}

Higiene dos Alimentos (Importâncla de lovar bem as mãos, frutas e verduras)

\section{MAIO}

Alimentos energéticos - a fonte que precisamos para pular, correr, etc.

Alimentos construtores - o cálicio e sua importância para os ossos e dentes.

Energéticos Extras: entre eles também há aproveitamento para o corpo - o bolo de cenoura é nutritivo e faz bem para a visōo la vitamina de cenoura)

Aprendendo a conservar os alimentos

\section{JUNHO}

Aproveitamento dos alimentos (reciclagem e economia)

\section{DE JUNHO}

Projeto Educacional para uma vida Soudóvel.

AT

\section{Salada verde \\ Roda de conversa; \\ Resgate do passeio da "Boneca Camila" \\ (corpo humano).} Laboratório de Cléncias lobsenaçāo de micróbios no microscópio)

Plzza de bolacha de água e sal, integrando com atvidade do livro de linguagem oral $\theta$ escrita.

Dia do logurte e do queljo;

Integração com o passelo da boneca Camila.

Bolo de cenoura e chocolate:

Integração com o passeio d boneca Camila.

Observaçōo de prazos de valldade nos alimentos, refrigeração necessćria, etc.

Observação de fungos e bolores em päes, leite, queljo, etc.

Casquinha
aperitivos)

ATIVIDADES

Mostra do Conhecimento 


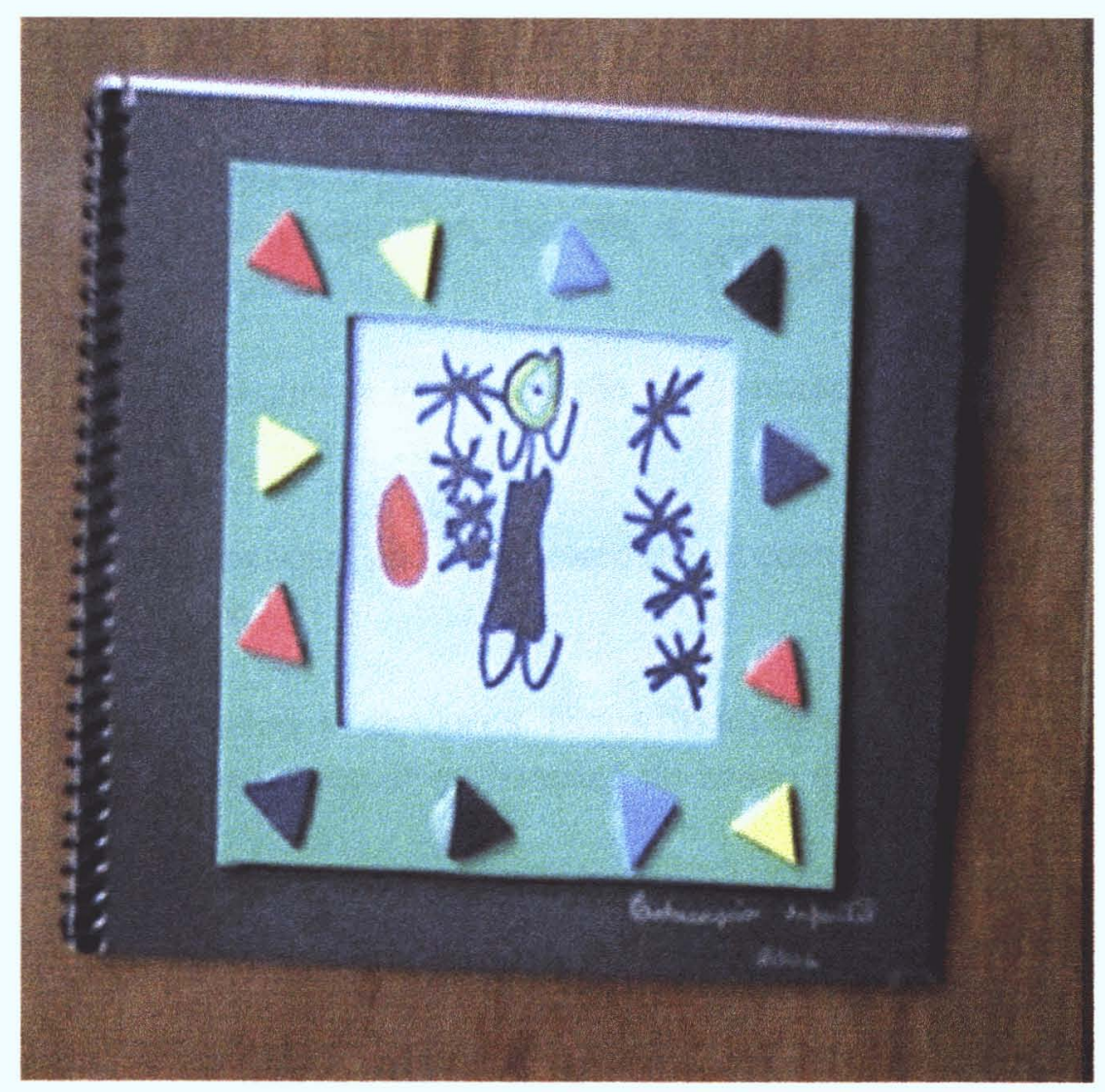


Dicas para uma alimentação saudável

Para ter energia e poder estudar, correr, nadar, pular e brincar, seu filho precisa de alimentos energéticos como arroz, pão com margarina, batata e macarrão.
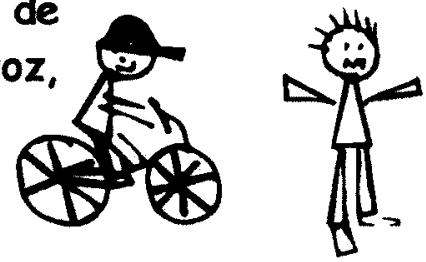

Leite, iogurtes e queijos são importantes para formar ossos e dentes fortes!

Para crescer, são fundamentais as carnes, leites, ovos e feijão.

As frutas e verduras têm vitaminas e minerais que ajudam a regular as funções do nosso corpo.

Beber bastante água é importante para manter o corpo hidratado.

Transformar pequenos momentos de refeição em familia em grandes oportunidades para o convivio agradável entre pais e filhos. Aqui começa todo o segredo de uma alimentação saudável! 


\section{RECEITAS DOCES}

\section{BANANA ESPERTA}

INGREDIENTES

$1 / 2 \mathrm{dz}$ de banana sem casca

farofa doce ou paçoquinha

mel ou Karo

Canela em pó a gosto

MODO DE PREPARO

Corte as bananas em tiras longas. Passe as tiras no mel e, com a ajuda de um garfo, deixe escorrer o excesso.

Arrume as bananas em assadeira e polvilhe a farofa por cima.

Leve ao forno por 10 minutos e sirva depois de frio.

DICA

Sirva acompanhada com sorvete de creme.

VALOR NUTRITIVO

Esta preparação é rica em carboidratos e potássio. 


\section{BANANA À MILANESA}

INGREDIENTES:

$1 / 2 \mathrm{dz}$ banana nanica não madura

1 ovo

farinha de rosca

1 pitada de sal

óleo para fritar

MODO DE PREPARO:

Bata levemente o ovo com um garfo e acrescente o sal. Passe a banana descascada no ovo e em seguida na farinha de rosca.

Frite em óleo bem quente.

\section{DICAS}

- o óleo deve ser em quantidade sufíciente para cobrir a banana durante a fritura.

- a banana não deve ser muito madura para que não se desmanche ao fritar.

VALOR NUTRITIVO

Fornece carboidratos, gordura e potássio 


\section{BISCOITINHO DE POLVILHO DOCE}

\section{INGREDIENTES}

$250 \mathrm{~g}$ de margarina

$500 \mathrm{~g}$ de polvilho doce

2 ovos

$100 \mathrm{~g}$ de coco ralado

1 e $1 \frac{1}{2}$ xícara (chá) de açúcar

\section{MODO DE PREPARO}

Misture bem todos os ingredientes. Enrole a massa como nhoque e modele os biscoitinhos como preferir.

Coloque em forma não untada e asse em forno moderado.

\section{DICA}

- Depois de assados, coloque os biscoitinhos em pote bem tampado para que se conserve por mais tempo.

- Sugestão para mandar na lancheira.

VALOR NUTRITIVO

Carboidratos

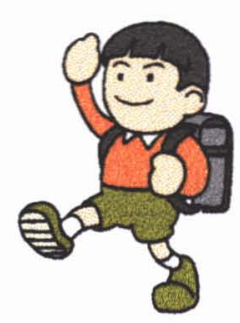




\section{BOLINHO DE CHUVA}

\section{INGREDIENTES}

4 xícaras (chá) de farinha de trigo

4 ovos

1 xícara (chá) de açúcar

1 colher (sopa) de fermento em pó

1 e $1 \frac{2}{2}$ xícara (chá) de leite

óleo para fritar

açúcar e canela para polvilhar

\section{MODO DE PREPARO}

Misture bem todos os ingredientes, com exceção do leite. Acrescente o leite aos poucos, até obter uma massa cremosa consistente.

Com o auxílio de uma colher, forme os bolinhos e frite em óleo quente, com o fogo baixo.

Deixe escorrer o óleo em papel toalha. Passe os bolinhos pelo açúcar e canela.

DICA

- Recheie os bolinhos com pedacinhos de frutas como banana ou maçã. Fica uma delícia.

- Pode ser mandado na lancheira.

\section{VALOR NUTRITIVO}

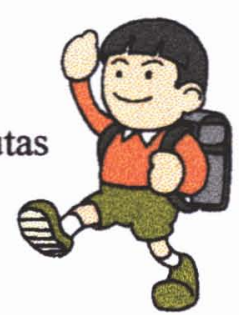

Carboidratos, gordura e proteína. 


\section{ESPETINHO DE FRUTAS COM CHOCOLATE}

\section{INGREDIENTES}

$300 \mathrm{~g}$ de uva itália

1 caixa de morangos

$200 \mathrm{~g}$ de chocolate ao leite

\section{MODO DE PREPARO}

Em um espetinho para churrasco, coloque as frutas, alternando entre morango e uva.

Derreta o chocolate em banho-maria e espere esfriar.

Passe o espetinho no chocolate derretido, deixe escorrer para tirar o excesso. Leve à geladeira para que o chocolate endureça.

\section{DICAS}

- Faça espetinhos somente com a fruta de sua preferência.

- Se desejar fazer com banana, coloque-a no freezer por alguns minutos antes de banhá-la no chocolate.

- Mande na lancheira de seu filho

VALOR NUTRITIVO

Carboidratos e vitaminas

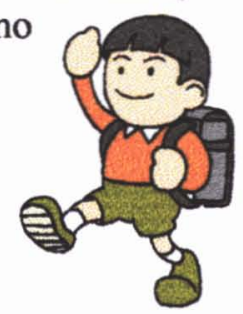




\section{LEITE CONDENSADO CASEIRO}

\section{INGREDIENTES}

1 xícara (chá) de leite em pó

1 xícara (chá) de açúcar

$1 / 2$ xícara (chá) de água fervente

\section{MODO DE PREPARO}

Bata os ingredientes no liqüidificador até obter consistência de leite condensado.

\section{DICA}

Esta preparação substitui o leite condensado em qualquer preparação

VALOR NUTRITIVO

Carboidratos e proteína 


\section{MOUSSE RÁPIDO DE MARACUJÁ}

\section{INGREDIENTES}

3 unidades de maracujá

1 lata de creme de leite

1 lata de leite condensado

\section{MODO DE PREPARO}

Faça um suco de maracujá concentrado, com pouca água.

Bata no liqüidificador o suco concentrado, o creme de leite e o leite condensado, até que fique bem misturado.

Leve 0 creme à geladeira por aproximadamente 1 hora.

\section{DICA}

Sirva esta deliciosa sobremesa na própria casca do maracujá. Se desejar, pode substituir o maracujá por 2 limões.

\section{VALOR NUTRITIVO}

Esta preparação é rica em cálcio e carboidratos. 


\section{MOUSSE DE CHOCOLATE}

\section{INGREDIENTES}

1 lata de creme de leite

$200 \mathrm{~g}$ de chocolate meio amargo em barra

3 claras

2 colheres (sopa) de açúcar

\section{MODO DE PREPARO}

Derreta o chocolate com o creme de leite em banho-maria. Misture bem até obter um creme homogêneo.

Bata as claras em neve com o açúcar. Misture ao creme e leve à geladeira.

VALOR NUTRITIVO

Carboidratos e proteínas 


\section{PUDIM RÁPIDO}

\section{INGREDIENTES}

1 lata de leite condensado

1 lata de creme de leite

1 caixinha de maria mole dissolvida em 1 copo de água quente

$200 \mathrm{ml}$ de leite

\section{MODO DE PREPARO}

Bata em liqüidificador todos os ingredientes.

Coloque em fôrma para pudim e leve à geladeira.

\section{DICAS}

- Sirva com calda de caramelo ou pêssego.

- Você pode substituir o leite por 1 vidrinho de leite de coco.

VALOR NUTRITIVO

Carboidratos, proteínas e cálcio 


\section{BOLO DE CENOURA}

\section{INGREDIENTES}

Bolo:

3 cenouras médias

4 ovos

$1 / 2$ xícara (chá) de óleo

3 xícaras (chá) de farinha de trigo

3 xícaras (chá) de açúcar

1 colher (chá) de fermento em pó

Cobertura:

1 xícara (chá) de chocolate em pó

1 xícara (chá) de açúcar

1 colher (sopa) de margarina

3 colheres (sopa) de leite

\section{MODO DE PREPARO}

Corte a cenoura em pequenos cubos e bata no liqüidificador junto com os ovos e o óleo, até obter um creme homogêneo.

Coloque em uma tigela e acrescente a farinha, o açúcar e o fermento. Misture bem até obter uma massa cremosa.

Leve para assar por 30 minutos em forno previamente aquecido.

Cobertura: Misture bem os ingredientes e aqueça-os em banho-maria. Cubra o bolo ainda quente.

\section{DICA}

- Este bolo pode ser congelado por 3 meses.

- Sugestão para mandar na lancheira.

VALOR NUTRITIVO

Fornece carboidratos e vitamina $\mathrm{A}$

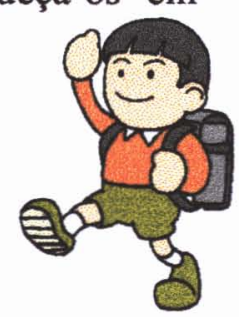




\section{BOLO DE CHOCOLATE NUTRITIVO}

\section{INGREDIENTES}

\section{Massa}

$300 \mathrm{~g}$ de figado de galinha cru

2 xícaras (chá) de chocolate em pó

$1 / 2$ xícara (chá) de água quente

6 ovos

$31 / 2$ xícaras (chá) de açúcar

1 xícara (chá) de óleo

3 xícaras (chá) de farinha de trigo

1 colher (sopa) de fermento em pó

Cobertura

1 lata de leite condensado

1 lata de leite integral

4 colheres (sopa) de chocolate em pó

2 colheres (sopa) de margarina

10 colheres (sopa) de chocolate granulado

\section{MODO DE PREPARO}

Bolo - Bata o figado no liqüidificador, passe na peneira e reserve.

Dissolva o chocolate em pó na água quente e junte o fígado batido.

Bata as gemas em batedeira até que fiquem embranquecidas. Junte o açúcar, o óleo e a mistura de chocolate, batendo sempre.

Acrescente as claras em neve misturando levemente. Em seguida, misture a farinha de trigo e o fermento.

Coloque em forma untada e enfarinhada, levando para assar em forno médio por 30 minutos. 
Cobertura - Misture todos os ingredientes e leve ao fogo, mexendo sempre, até que desgrude da panela.

Passe sobre o bolo previamente furado e decore com chocolate granulado.

DICA

- Este bolo pode ser congelado por até 3 meses.

- É uma ótima opção para mandar na lancheira.

VALOR NUTRITIVO:

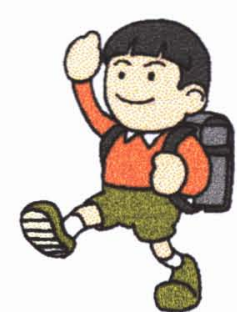

Uma porção de $85 \mathrm{~g}$ fornece $20,3 \%$ das necessidades diárias de ferro e $183,2 \%$ nas necessidades de vitamina A

Observação: esta receita foi elaborada por um grupo de alunos do curso de nutrição da USP, com o intuito de servir como alternativa de preparação rica em ferro, alcançando as crianças com anemia. 


\section{RECEITAS SALGADAS}

\section{ESPAGUETE DA HORTA}

\section{INGREDIENTES}

$500 \mathrm{~g}$ de espaguete cozido

1 maço de couve-flor

1 maço de brócolos

1 cenoura média

$150 \mathrm{~g}$ de vagem

2 dentes de alho amassados

sal a gosto

1 colher (sopa) de azeite ou margarina

\section{MODO DE PREPARO}

Cozinhe separadamente a couve-flor, o brócolos, a cenoura e a vagem.

Doure o alho no azeite ou margarina e refogue o macarrão.

Acrescente as hortaliças já cozidas e misture ao macarrão.

\section{DICAS}

- Cozinhe as hortaliças em pouca água para que não haja muita perda de vitaminas e minerais.

- Acrescente outras hortaliças de sua preferência.

VALOR NUTRITIVO

Carboidratos, vitaminas e minerais. 


\section{PATÊ DE RICOTA}

\section{INGREDIENTES}

1 xícara de ricota amassada

$1 / 2$ xícara de maionese

sal à gosto

\section{MODO DE PREPARO}

Misture todos os ingredientes e servir como recheio de pães, torradas ou bolachas.

\section{DICAS}

- A partir desta base de patê, você pode acrescentar ingredientes coloridos, obtendo sabores mais apurados, melhorando a aparência e aumentado o valor nutritivo.

Verde: salsinha e cebolinha ou azeitonas verdes picadinhas ou espinafre refogado

Amarelo: cenoura ralada

Vermelho: beterraba ralada

Preto: azeitonas pretas

- Recheie pães e mande na lancheira

\section{VALOR NUTRITIVO}

Fornece proteínas e cálcio

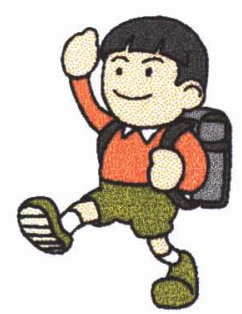




\section{PIZZA RÁPIDA}

\section{INGREDIENTES}

Massa:

1 xícara (chá) de leite

2 colheres (sopa) de óleo

1 ovo

2 e $\frac{1}{2}$ xícaras (chá) de farinha de trigo

Recheio:

1 xícara (chá) de molho de tomate

$300 \mathrm{~g}$ de queijo tipo mussarela fatiada ou ralada

orégano

azeite

\section{MODO DE PREPARO}

Unte uma forma média e reserve.

Coloque o forno para aquecer em temperatura moderada.

Em um recipiente, junte o leite, o óleo e o ovo. Misture bem.

Acrescente aos poucos a farinha de trigo e misture com as mãos até obter uma massa homogênea que desgrude das mãos. Se necessário, acrescente mais farinha de trigo.

Abra a massa com um rolo e forre a forma reservada.

Distribua o molho de tomate, a mussarela, salpique o orégano e regue com o azeite. Leve para assar no forno por cerca de 15 minutos ou até que o fundo esteja dourado.

DICA

Você pode fazer o recheio de sua preferência.

VALOR NUTRITIVO

Esta preparação fornece carboidratos e proteínas. 


\section{MOLHO BRANCO 2 QUEIJOS}

\section{INGREDIENTES}

$200 \mathrm{~g}$ de queijo tipo gorgonzola

$100 \mathrm{~g}$ de queijo tipo parmesão ralado

2 colheres de margarina

1 copo $(250 \mathrm{ml})$ de leite

1 lata de creme de leite

\section{MODO DE PREPARO}

Em uma panela, misture todos os ingredientes, com exceção do creme de leite. Leve ao fogo, mexendo sempre, até obter um creme homogêneo.

Acrescente por último o creme de leite, sem deixá-lo ferver.

\section{DICAS:}

Este saboroso molho acompanha massas e gratinados.

\section{VALOR NUTRITIVO:}

Fornece proteínas, gordura e cálcio. 


\section{TORTA DE LIQUIDIFICADOR}

\section{INGREDIENTES}

\section{Massa:}

3 ovos

1 copo de óleo

1 copo de leite

2 copos de farinha de trigo

1 colher (sopa) de fermento

3 colheres (sopa) queijo ralado

Recheio:

Faça um refogado com os ingredientes que mais lhe agradar, como por exemplo: atum, milho, ervilha, ovo cozido, cebola, frango desfiado, carne moída....

\section{MODO DE PREPARO:}

Bata todos os ingredientes da massa no liqüidificador. Unte e polvilhe uma assadeira e coloque a metade da massa batida.

Coloque o recheio de sua preferência e cubra com o restante da massa.

Leve para assar em forno brando, até que fique dourada.

\section{DICAS}

Esta preparação pode ser congelada por até 3 meses.

Sugestão para mandar na lancheira.

VALOR NUTRITIVO

Fornece carboidratos, proteínas e cálcio.

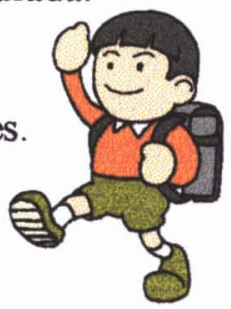




\section{CREME DE MILHO}

\section{INGREDIENTES}

\section{2 copos de leite}

2 colheres (sopa) de amido de milho

1 colher (sopa) de queijo ralado

1 colher (sopa) de margarina

1 lata de milho verde

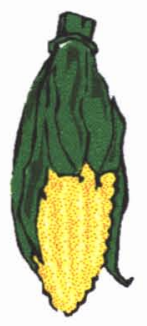

\section{MODO DE PREPARO}

Bata a metade do milho com toda a água no liqüidificador e reserve.

Faça um creme com o leite, o amido, a margarina e o queijo, cozinhando em fogo baixo. Junte o milho batido e o restante, cozinhando até obter a consistência desejada.

DICA

Para fazer um creme de espinafre, cozinhe o espinafre com pouca água e proceda da mesma forma feita com o milho. Bata metade em liqüidificador e a outra metade em fatias finas.

\section{VALOR NUTRITIVO}

Fornece carboidratos e proteínas 


\section{TOMATES RECHEADOS}

\section{INGREDIENTES}

$1 / 2 \mathrm{dz}$ de tomates grandes e firmes

1 lata de milho verde

1 lata de ervilha

3 colheres de batata palha

1 cenoura ralada

3 colheres de requeijão

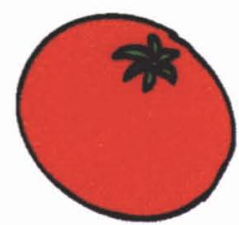

MODO DE PREPARO

Corte uma fatia fina do tomate, próxima à parte superior, de forma que o mesmo fique inteiro, com uma "tampinha". Retire toda a polpa do tomate e reserve.

Em uma tigela, misture a polpa do tomate e os demais ingredientes.

Recheie os tomates com a pasta preparada.

DICAS

- O recheio pode ser do sabor de sua preferência.

- Faça desenho de um rostinho no tomate, utilizando maionese e mostarda.

VALOR NUTRITIVO

Esta é uma preparação rica em vitaminas e minerais. 


\section{MASSA BÁSICA PARA PANQUECA}

\section{INGREDIENTES}

2 copos $(440 \mathrm{ml})$ de leite

6 colheres (sopa) de farinha de trigo

1 colher (chá) de fermento em pó

2 ovos

sal a gosto

margarina ou óleo para fritar

\section{MODO DE PREPARO}

Bata todos os ingredientes no liqüidificador. Em uma frigideira pequena, coloque pedacinhos de margarina. Com o auxílio de uma concha, vá colocando porção da massa até formar uma camada fina. Vire a massa, deixando dourar dos dois lados.

Acrescente $o$ recheio de sua preferência e enrole as panquecas.

DICA

Arrume as panquecas em refratário, acrescente o molho de sua preferência e salpique queijo ralado. Leve ao forno para gratinar.

VALOR NUTRITIVO

Formece carboidratos e proteínas 


\section{PEITO DE FRANGO ASSADO}

\section{INGREDIENTES:}

$1 \mathrm{Kg}$ de peito de frango com osso alho, cebola e sal para temperar margarina para untar o frango

\section{MODO DE PREPARO:}

Tempere o frango à gosto e coloque em assadeira. Passe a margarina por cima do frango e cubra a assadeira com papel alumínio.

Leve ao forno para assar por aproximadamente 1 hora. Retire o papel alumínio e deixe mais alguns minutos no forno até que o frango fique dourado.

DICAS

O frango deve ser assado com pele para que não fique ressecado.

VALOR NUTRITIVO

Fomece proteínas 


\section{FRANGO ASSADO COM FLOCOS DE MILHO}

\section{INGREDIENTES}

$1 \mathrm{Kg}$ de frango em pedaços

$500 \mathrm{ml}$ de leite

$200 \mathrm{~g}$ de flocos de milho (sem açúcar)

1 colher (sopa) de salsinha picada

2 dentes de alho amassados

1 colher (sopa) de amido de milho

sal a gosto

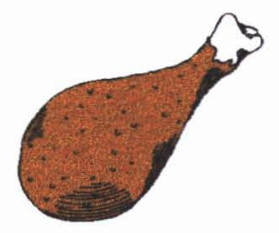

\section{MODO DE PREPARO}

Lave bem o frango e retire toda a pele. Acomode o frango em recipiente e cubra com leite.

Deixe repousar por uma noite dentro da geladeira, bem tampado.

Misture em uma vasilha os flocos de milho ligeiramente moídos, o amido, a salsinha e o sal.

Passe os pedaços de frango, um a um, pela mistura de flocos de milho, apertando bem com as mãos para que fique bem empanado.

Acomode o frango em assadeira e leve ao forno pré-aquecido por 40 minutos.

DICA

Sirva com purê de batatas e salada.

VALOR NUTRITIVO

Fornece proteínas e carboidratos 


\section{BATATA ASSADA (MICROONDAS)}

\section{INGREDIENTES}

$1 / 2 \mathrm{dz}$ de batata inglesa tamanho médio

\section{MODO DE PREPARO}

Lave bem as batatas e coloque, uma a uma, em refratário próprio para microondas.

Asse por 8 minutos em potência alta e deixe descansar por 2 minutos.

Faça um corte na batata e acrescente o recheio de sua preferência.

DICA

Você pode utilizar como recheio: margarina, requeijão, patês, strogonoffe e outros.

VALOR NUTRITIVO

Fornece carboidratos

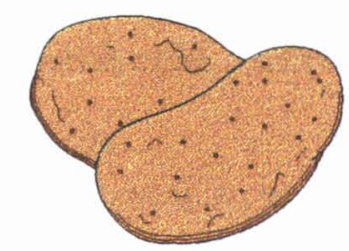




\section{BOLINHO DE ESPINAFRE}

\section{INGREDIENTES}

1 maço de espinafre cozido, escorrido e picado

2 ovos

1 pacote pequeno de queijo ralado

$1 / 2$ copo de leite

1 colher (café) de fermento em pó

farinha de trigo até obter o ponto de massa de bolinho para

fritar

óleo para fritar

\section{MODO DE PREPARO}

Misture todos os ingredientes, menos a farinha. Acrescente aos poucos a farinha de trigo, mexendo sempre até atingir consistência para porcionar com colher e fritar em óleo quente.

Sirva na refeição como acompanhamento.

DICA

Use outras hortaliças como recheio, tais como: brócolos, escarola, cenoura, abobrinha, milho, etc.

\section{VALOR NUTRITTVO}

Formece proteínas, vitamina A, ferro e gordura. 


\section{BOLINHO DE ARROZ}

\section{INGREDIENTES}

2 xícaras (chá) de arroz cozido

$1 / 2$ xícara (chá) de farinha de trigo

$100 \mathrm{~g}$ de queijo ralado

1 ovo

1 colher (sopa) de salsinha picadinha

óleo para fritar

\section{MODO DE PREPARO}

Amasse o arroz com um garfo e acrescente os demais ingredientes.

Faça os bolinhos e frite em óleo bem quente.

DICAS

Faça esta receita com a sobra de arroz.

VALOR NUTRITIVO

Fornece carboidratos e gordura 


\section{SUCOS E BEBIDAS}

\section{SUCO DE COUVE}

\section{INGREDIENTES}

3 limões bem lavados, cortados em rodelas

2 folhas de couve bem lavadas, com os talos

1 litro de água

açúcar a gosto

\section{MODO DE PREPARO}

Bata todos os ingredientes em liqüidificador, coe e sirva em seguida.

\section{DICAS}

- Este suco deve ser bebido tão logo seja preparado para que não tenha sua aparência alterada e nem perda das vitaminas.

- Pode ser acrescentado ao suco, abacaxi ou laranja

VALOR NUTRITIVO

Fomece vitaminas $\mathrm{A}$ e $\mathrm{C}$, ferro e carboidratos. 
PONCHE DE FRUTAS (S/ ÁLCOOL)

INGREDIENTES

1 abacaxi

6 maçãs

2 mangas grandes

1 lata de pêssego em calda

1 caixa de morangos

6 litros de guaraná gelado

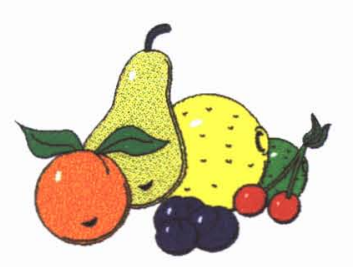

MODO DE PREPRARO

Descasque e corte em cubos todas as frutas. Misture, em recipiente grande, todas as frutas e acrescente o guaraná.

Conserve em geladeira e servir 12 horas após o preparo.

\section{DICAS}

- Para obter uma cor rosada, acrescente 3 xícaras (chá) de groselha.

- Esta é uma ótima bebida para ser servida em festa.

VALOR NUTRITIVO

Fomece vitaminas, fibras e carboidratos 


\section{VITAMINA DE MARACUJÁ}

\section{INGREDIENTES}

3 unidades de maracujá

1 litro de leite

açúcar a gosto

\section{MODO DE PREPARO}

Faça um suco concentrado com a polpa do maracujá. Passe pela peneira.

Bata em liqüidificador a polpa do suco, o leite e o açúcar.

Sirva gelado.

DICA

Acrescentar um copo de iogurte natural, fica ainda mais cremoso e saboroso.

VALOR NUTRITIVO

Fornece cálcio e proteínas.

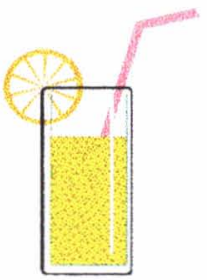

